University of Wollongong

Research Online

Faculty of Science - Papers (Archive) Faculty of Science, Medicine and Health

$1-1-2008$

\title{
Ti-in-zircon thermometry applied to contrasting Archean metamorphic and igneous systems
}

Joe Hiess

NERC Isotope Geosciences Laboratory

Allen Phillip Nutman

University of Wollongong, anutman@uow.edu.au

Vickie C. Bennett

Australian National University

Peter Holden

Follow this and additional works at: https://ro.uow.edu.au/scipapers

Part of the Life Sciences Commons, Physical Sciences and Mathematics Commons, and the Social and Behavioral Sciences Commons

\section{Recommended Citation}

Hiess, Joe; Nutman, Allen Phillip; Bennett, Vickie C.; and Holden, Peter: Ti-in-zircon thermometry applied to contrasting Archean metamorphic and igneous systems 2008, 323-338.

https://ro.uow.edu.au/scipapers/907

Research Online is the open access institutional repository for the University of Wollongong. For further information contact the UOW Library: research-pubs@uow.edu.au 


\title{
Ti-in-zircon thermometry applied to contrasting Archean metamorphic and igneous systems
}

\begin{abstract}
Ti-in-zircon thermometry with SHRIMP II multi-collector has been applied to two well-documented Archean igneous and metamorphic samples from southern West Greenland. Zircons from 2.71 Ga partial melt segregation $\mathrm{G} 03 / 38$ formed in a small $(<1>\mathrm{m}(3))$, closed system within a mafic rock under high pressure granulite facies conditions. Results of $14 \mathrm{Ti}$ analyses present a mean apparent zircon crystallization temperature of $679+/-11$ degrees $C$, underestimating independent garnet-clinopyroxene thermometry by 20-50 degrees $\mathrm{C}$ but consistent with reduced a(TiO2) in this system. 36 spot analysis on 15 zircons from $3.81 \mathrm{Ga}$ meta-tonalite $\mathrm{G} 97 / 18$, with an estimated magmatic temperature $>1000$ degrees $C$, yield a low-temperature focused normal distribution with a mean of $683+/-32$ degrees $C$, further demonstrated by high resolution Ti mapping of two individual grains. This distribution is interpreted to represent the temperature of the residual magma at zircon saturation, late in the crystallization history of the tonalite. Hypothetically, Ti-in-zircon thermometry on Eoarchaean detrital zircons sourced from such a high temperature tonalite would present a low-temperature biased image of the host magma, which could be misconstrued as being a minimum melt granite. Multiple analyses from individual zircons can yield complex Ti distributions and associated apparent temperature patterns, reflecting cooling history and local chemical environments in large magma chambers. In addition to inclusions and crystal imperfections, which can yield apparent high temperature anomalies, zircon surfaces can also record extreme (>1000 degrees $\mathrm{C}$ ) apparent Ti temperatures. In our studies these were traced to (49)Ti (or a molecular isobaric interference) contamination derived from the double sided adhesive tape used in sample preparation, and should not be assigned geological significance. (C) 2007 Elsevier B.V. All rights reserved. Document Type: Article
\end{abstract}

\section{Keywords}

ti, metamorphic, archean, igneous, contrasting, systems, applied, thermometry, zircon, GeoQUEST

\section{Disciplines}

Life Sciences | Physical Sciences and Mathematics | Social and Behavioral Sciences

\section{Publication Details}

Hiess, J., Nutman, A. Phillip., Bennett, V. C. \& Holden, P. (2008). Ti-in-zircon thermometry applied to contrasting Archean metamorphic and igneous systems. Chemical Geology, 247 (3-4), 323-338. 


\section{Ti-in-zircon thermometry applied to contrasting}

\section{Archean metamorphic and igneous systems}

\section{3}

$10{ }^{\mathrm{a}}$ Research School of Earth Sciences, Australian National University, Canberra, ACT

11 0200, Australia

$12{ }^{\mathrm{b}}$ Institute of Geology, Chinese Academy of Geological Sciences, 26 Baiwanzhuang Road,

13 Beijing, 100037, China

\section{Joe Hiess $^{\mathrm{a} *}$, Allen P. Nutman ${ }^{\mathrm{b}}$, Vickie C. Bennett ${ }^{\mathrm{a}}$, Peter Holden ${ }^{\mathrm{a}}$}

*Corresponding author.

Research School of Earth Sciences, Building 61, Mills Rd, Australian National

University, Canberra, ACT, 0200, Australia.

Phone: +612 61255472.Fax: +612 61250738.Email: joe.hiess@anu.edu.au

Word count: 261 (abstract)

5592 (text)

973 (references)

621 (captions)

Number of figures: 9

Number of tables: 3

Number of background datasets: 2

(Figures 1, 2, 5, 6 and 9 in black and white for web and print; Figures 3 and 4 in color for web and in black and white for print; Figures 7 and 8 in color for web and print) 


\section{Abstract}

33 Ti-in-zircon thermometry with SHRIMP II multi-collector has been applied to two well-

34 documented Archean igneous and metamorphic samples from southern West Greenland.

35 Zircons from 2.71 Ga partial melt segregation G03/38 formed in a small $\left(<1 \mathrm{~m}^{3}\right)$, closed

36 system within a mafic rock under high pressure granulite facies conditions. Results of 14

$37 \mathrm{Ti}$ analyses present a mean apparent zircon crystallization temperature of $679 \pm 11^{\circ} \mathrm{C}$,

38 underestimating independent garnet-clinopyroxene thermometry by $20-50^{\circ} \mathrm{C}$ but

39 consistent with reduced $a_{\mathrm{TiO} 2}$ in this system. 36 spot analysis on 15 zircons from $3.81 \mathrm{Ga}$

40 meta-tonalite G97/18, with an estimated magmatic temperature $>1000^{\circ} \mathrm{C}$, yield a low-

41 temperature focused normal distribution with a mean of $683 \pm 32^{\circ} \mathrm{C}$, further demonstrated

42 by high resolution Ti mapping of two individual grains. This distribution is interpreted to

43 represent the temperature of the residual magma at zircon saturation, late in the

44 crystallization history of the tonalite. Hypothetically, Ti-in-zircon thermometry on

45 Eoarchaean detrital zircons sourced from such a high temperature tonalite would present

46 a low-temperature biased image of the host magma, which could be misconstrued as

47 being a minimum melt granite. Multiple analyses from individual zircons can yield

48 complex Ti distributions and associated apparent temperature patterns, reflecting cooling

49 history and local chemical environments in large magma chambers. In addition to

50 inclusions and crystal imperfections, which can yield apparent high temperature

51 anomalies, zircon surfaces can also record extreme $\left(>1000^{\circ} \mathrm{C}\right)$ apparent Ti temperatures.

52 In our studies these were traced to ${ }^{49} \mathrm{Ti}$ (or a molecular isobaric interference)

53 contamination derived from the double sided adhesive tape used in sample preparation,

54 and should not be assigned geological significance.

56 Keywords: Ti thermometry; zircon; Archean; Greenland; Isua; tonalite 


\section{1. Introduction}

63 Incorporation of titanium into crystallizing zircon is seemingly primarily controlled by 64 temperature and $a_{\mathrm{TiO} 2}$ (Watson et al., 2006), and once within the zircon structure has a 65 very low diffusivity under geologic conditions (Cherniak and Watson, 2007). This

66 thermometer then, has the potential to yield valuable information on the thermal

67 evolution of metamorphic and igneous rocks. Initial application of the Ti-in-zircon

68 thermometer was to 3.91-4.35 Ga detrital zircons from the Jack Hills, Western Australia.

69 The low temperature distributions obtained were used to propose the existence of

70 prograde, wet minimum melting conditions during formation of the granitic protolith to

71 the Hadean zircons (Watson and Harrison, 2005, 2006; Harrison and Schmitt, 2007;

72 Harrison et al. 2007). This hypothesis caries far reaching implications for the dynamics of

73 the early earth and has since stimulated ongoing debate (Nutman, 2006; Valley et al.,

74 2006; Coogan and Hinton, 2006). In order to further explore the validity of applying the

75 experimentally determined Ti-in-zircon thermometer to natural systems, we have

76 examined zircons separated from Archean rocks formed in different conditions. This has

77 the advantage that the chemistry and geologic setting of the host rocks are well known

78 and provides for a more detailed understanding of what Ti signatures from Archean and

79 Hadean detrital zircon populations may reveal about early Earth environments.

81 The new Ti thermometry results are from zircons from two contrasting Archean samples

82 from southern West Greenland. The first, a 3.81 Ga meta-tonalite represents some of the

83 best preserved Eoarchean felsic crust yet discovered. Such tonalites typically crystallize

84 as large volume magma chambers from melting initiating above $1000^{\circ} \mathrm{C}$ (Rapp and

85 Watson, 1995). The second sample is from a local, trondhjemitic, minimum melt

86 segregation associated with high pressure granulite facies metamorphism. Each sample

87 has previously determined $\mathrm{U} / \mathrm{Pb}$ zircon geochronology, petrogenetic constraints and

88 information relevant to the thermal evolution of the rocks (Nutman et al., 1989, 1999;

89 Nutman and Friend, 2007), allowing assessment of under what situations Ti-in-zircon

90 thermometry is best applied. 


\section{2. Samples}

\subsection{81 Ga meta-tonalite sample G97/18}

96 G97/18 is part of the exceptionally well-preserved suite of 3.8 Ga meta-plutonic rocks

97 located between the Isua supracrustal belt and $65^{\circ} \mathrm{N}$, initially reported by Nutman et al.

98 (1999). The sample is a homogeneous biotite \pm hornblende meta-tonalite with relict

99 igneous texture and very weak biotite foliation (Figure 2 in Nutman et al. (1999)). The

100 trace element characteristics of this sample are typical of Archean tonalite-trondhjemite-

101 granodiorite (TTG) suites, with for example light rare earth element (REE) enrichment,

102 heavy REE depletion, and high Sr/Y. The bulk chemistry of this sample can be modeled

103 by ca. $30 \%$ melting of a mafic rock under sufficient pressure to stabilize residual garnet

104 and clinopyroxene (eclogite), with little or no plagioclase fractionation superimposed

105 during emplacement into the crust (Nutman et al., 1999). Extensive experimental data

106 shows that such compositions require temperatures above $1000^{\circ} \mathrm{C}$ to form (Rapp and

107 Watson, 1995), and thereby would be classified as "hot" granites.

109 Zircons in the sample are euhedral to subhedral prisms, with generally well-preserved

110 oscillatory igneous zonation. U/Pb geochronology provides a weighted mean ${ }^{207} \mathrm{~Pb} /{ }^{206} \mathrm{~Pb}$

111 age of $3808 \pm 4 \mathrm{Ma}(\mathrm{n}=26, \mathrm{MSWD}=1.9)$ for oscillatory zoned zircon (Nutman et al.,

112 1999). Crowley (2003) replicated these ages in a U/Pb zircon study using ID-TIMS of

113 tonalites from the same outcrop. There are rare low $\mathrm{Th} / \mathrm{U}$ replacement domains on the

114 edges of grains as old as $3790 \mathrm{Ma}$, and some other rare recrystallisation domains have

115 yielded ages as young as $3600 \mathrm{Ma}$ (Nutman et al., 1999). Petrographic studies indicate

116 some zircons contain ilmenite inclusions (Figure 1), which are interpreted to be the

117 predominant Ti-rich phase in equilibrium with the growing igneous zircon. Zircons from

118 this rock, owing to their antiquity, narrow range of ages, and general absence of younger

119 overgrowths have been used in number of geochemical studies including determining the

120 xenon isotopic composition of the Earth at 3.81 Ga. (Honda et al., 2003).

\subsection{71 Ga partial melt segregation $G 03 / 38$}


123 G03/38 collected from Qilanngaarsuit Island, Nuuk district, southern West Greenland

124 was initially reported by Nutman and Friend (2007). The island is dominated by outcrop

125 of the Eoarchaean Itsaq Gneiss Complex (Nutman et al., 1996; Nutman and Friend, 2007)

126 in mylonitic contact with a 2840 Ma tectonic supracrustal slice (Chadwick and Nutman,

127 1979). On the southern end of the island $\mathrm{a} \leq 200 \mathrm{~m}$ thick unit of amphibolite and

128 paragneiss preserves small domains of high pressure granulite assemblages. G03/38 is a

129 small $\left(<1 \mathrm{~m}^{3}\right)$, coarse grained, trondhjemitic segregation (Figure 3c. in Nutman and

130 Friend, 2007) in equilibrium with garnet, clinopyroxene and ilmenite from the rock's

131 high pressure granulite assemblage. Mixture modeling using MIX of M (Sambridge and

132 Compston, 1994) on 40 analyses from 29 grains indicated a major zircon age population

133 representing metamorphism at $2714 \pm 4 \mathrm{Ma}$ and a minor group representing

134 recrystallisation at $2690 \pm 6 \mathrm{Ma}$ (Nutman and Friend, 2007).

136 Zircons bear rare plagioclase and clinopyroxene inclusions, with only moderate HREE

137 enrichment and negative Eu anomalies, indicating the $2714 \mathrm{Ma}$ zircons should have

138 formed in equilibrium with garnet, clinopyroxene and plagioclase (Nutman and Friend,

139 2007). The high pressure granulites are commonly partially retrogressed to lower

140 pressure amphibolite facies assemblages, with the replacement of clinopyroxene by

141 hornblendic amphibole and garnet by symplectites containing plagioclase + hornblende.

142 However, locally, such as in sample G03/38, the higher-pressure assemblage is well

143 preserved, with minimal retrogression and many equilibrium boundaries preserved

144 between garnet + clinopyroxene + plagioclase + quartz (Figure 2). This suggests the

145 small trondhjemitic melt segregations developed in the field where dehydration melting

146 of amphibolites starts to occur, at pressures where garnet is stable (Wyllie and Wolf, 147 1993).

\section{3. Analytical methods}

152 Zircon separates previously extracted from rock samples by conventional crushing, heavy 153 liquid and magnetic techniques were used in this study. Approximately 60 grains from 
154 each sample were transferred onto double sided adhesive tape with a fine-tipped needle 155 under a binocular microscope and flattened onto their c-axis. The grains were shielded 156 with the adhesive tape's paper spacer before being set in epoxy with zircon reference 157 materials SL13 (Claoué-Long et al., 1995), FC1 (Paces and Miller, 1993) and Temora-2

158 (Black et al., 2003). For the initial analytical session a second mount containing SL13, 159 FC1, Temora-2 zircon reference materials; and NIST 610, 612 and 615 (Pearce et al., 160 1997) glass reference materials was made. Mounts were polished to expose crystal mid161 sections with a rotary polisher and $1 \mu \mathrm{m}$ diamond paste. All grains were imaged with 162 reflected light, transmitted light and cathodoluminesence spectroscopy to identify cracks, 163 inclusions and 2-dimensional growth structure to guide analysis. Prior to each analytical 164 session mounts were sequentially cleaned in an ultrasonic bath with petroleum spirits, 165 ethanol, diluted laboratory detergent, $1 \mathrm{M} \mathrm{HCl}$ solution, and deionized $\mathrm{H}_{2} \mathrm{O}$ before being 166 thoroughly dried in a $60^{\circ} \mathrm{C}$ oven. A $100 \AA$ Au coat was finally applied to the analytical 167 surface and checked to ensure uniform and adequate conductivity before loading into the 168 instrument.

170 Zircon Ti concentrations were determined using the SHRIMP II multi-collector ion 171 microprobe at the Australian National University over five analytical sessions. Data 172 acquisition and reduction protocols are presented in detail by Aikman (2007) and 173 summarized here. Isotopic ratios were produced by simultaneous measurement of ${ }^{49} \mathrm{Ti}^{+}$ 174 with a gain checked, Sjuts continuous dynode electron multiplier at the high mass 175 detector; and ${ }^{28} \mathrm{Si}^{16} \mathrm{O}^{+}$by Faraday cup at the low mass detector using count rates $>10^{6}$ 176 cps. $\mathrm{SiO}$ background counts $(\sim 0.1 \%$ of total $\mathrm{SiO}$ counts) were subtracted during setup 177 configuration, ${ }^{49} \mathrm{Ti}$ background counts (2-4 cps) were subtracted during data reduction.

178 Mass resolution was 5,000 at 1\% peak height. The low abundance ${ }^{49} \mathrm{Ti}$ isotope $(5.41 \%)$ 179 was chosen to avoid interference with ${ }^{96} \mathrm{Zr}^{2+}$ or ${ }^{48} \mathrm{Ca}^{+}$(from apatite inclusions) on the 180 major ${ }^{48} \mathrm{Ti}$ peak $(73.72 \%)$ as counting statistics were not a limiting factor for precision.

182 For spot analysis during the first four analytical sessions a 2.0 to $4.5 \mathrm{nA} \mathrm{O}_{2}{ }^{-}$primary 183 beam was focused to a $20 \mu \mathrm{m}$ diameter spot, producing a sensitivity of $>19 \mathrm{cps}{ }^{49} \mathrm{Ti} / \mathrm{ppm}$ $184 \mathrm{Ti} / \mathrm{nA} \mathrm{O}_{2}{ }^{-}$. Prior to the start of data acquisition a $120 \mu \mathrm{m}$ surface raster was programmed 
185 for 120 seconds to clean the analysis area and avoid Ti contamination from within the

186 gold coat. Data acquisitions consisted of 10-20, 10 second integrations.

188 Tabulated results from zircon and glass reference materials and the operating conditions

189 specific to each instrument session is presented in Background Dataset $1 . \mathrm{SiO} /{ }^{49} \mathrm{Ti}$ ratios

190 from zircon and glass reference materials are consistent for concentrations at the ppm

191 level. Internal precision from counting statistics of reference materials is better than $0.2 \%$

192 with external precision matching internal precision during periods of high performance.

193 The standard error from $\mathrm{SiO} /{ }^{49} \mathrm{Ti}$ ratios on $\mathrm{SL} 13$ was $<0.7 \%(\mathrm{n}=64)$ over all five sessions.

194 Temora-2 zircon, FC1 zircon, NIST 610, 612 and 615 glasses were analysed as secondary

195 reference materials to monitor instrument performance, but not directly used to calculate

196 zircon Ti abundances or temperatures.

198 As part of this study, the Ti concentrations of 23 grains of SL13, FC1 and Temora-2

199 (previously analysed by SHRIMP) were independently determined by LA-ICPMS.

200 Analysis was performed on the RSES Aligent 7500 ICPMS equipped with a Lamda

201 Physik LPX 1201 UV ArF eximer laser and Ar-He flushed sample cell (Eggins et al.,

202 1998). The laser operated at $22 \mathrm{Kv}$ with $100 \mathrm{~mJ}$ energy per pulse at $5 \mathrm{~Hz}$. The $54 \mu \mathrm{m}$

203 diameter spot was placed directly over the $\sim 1 \mu \mathrm{m}$ deep SHRIMP pits. Each acquisition

204 consisted of a 20 second background followed by a 20 second collection period. Blocks

205 of 10 unknowns were bracketed by analyses of NIST 610 and 612 glass reference

206 material. Raw counts were converted to concentrations using "LABRAT 0.93" written for

207 Lab VIEW by Antti Kallio. Corrections for mass bias drift in unknowns were made using

208 NIST 612. Zircon Ti abundances (Background Dataset 1) were normalized to

209 stoichiometric $\mathrm{SiO}_{2}$. The mean $(2 \sigma)$ Ti concentration of SL13 was found to be relatively

210 homogeneous (6.3 $\pm 0.3 \mathrm{ppm}, \mathrm{n}=10)$, while Temora-2 $(9.1 \pm 0.6 \mathrm{ppm}, \mathrm{n}=6)$ and FC1

$211(21.9 \pm 1.6 \mathrm{ppm}, \mathrm{n}=7)$ are subtly more heterogeneous.

212

213 Coinciding SHRIMP ( $\left.\mathrm{SiO} /{ }^{49} \mathrm{Ti}\right)$ and LA-ICPMS [Ti] zircon analyses vary approximately

214 linearly when plotted in $\left(\mathrm{SiO} /{ }^{49} \mathrm{Ti}\right)^{-1}$ vs [Ti] space. This array defines a matrix sensitive

215 regression through the mean value of SL13 and the origin (Figure 3A). This point and 
216 zero calibration line was used to reference the Ti concentration of unknowns from

217 measured $\mathrm{SiO} /{ }^{49} \mathrm{Ti}$ ratios with well characterized SL13 (Figures 3B and 3C). Ti

218 concentrations for SL13, analysed routinely (typically once every three unknowns during

219 spot analyses) is presented in Figure 3D. This calibration approach is currently limited by

220 reference material heterogeneity and the complex error magnification envelope for

221 unknowns with greater titanium content than the SL13 reference material. Relative errors

222 of $<5 \%$ are commonly achievable for most geologically useful titanium contents (1-40

223 ppm).

225 Command-line software "TiZer" (Aikman, 2007) has been written to process raw

226 SHRIMP multi-collector output files to Ti concentrations and temperatures. $\mathrm{SiO} /{ }^{49} \mathrm{Ti}$

227 ratios for single analyses are calculated from scan medians and corrected for drift through

228 the session by robust regression. Ratios are reduced to Ti concentrations using the

229 calibration line described above, and crystallization temperatures using the empirical

230 calibration defined by Watson and Harrison (2005) and Watson et al. (2006). Analytical

231 errors are a product of counting statistics, dispersion in measured $\mathrm{SiO} /{ }^{49} \mathrm{Ti}$ ratios of

232 reference materials, systematic errors in the Ti content of zircon reference materials

233 (measured by LA-ICPMS) and the uncertainty from the thermometer calibration. Each

234 component of uncertainty is independent. Ti concentration and temperature absolute

235 uncertainties $(2 \sigma$ level $)$ are derived by multiplying uncertainties from each term by their

236 partial derivatives and summing the results in quadrature.

238 Accurate knowledge of $a_{\mathrm{TiO} 2}$ and $a_{\mathrm{SiO} 2}$ at the time of zircon crystallization remains

239 fundamental to the accuracy of the thermometer. Both samples indicate simultaneous

240 crystallization of quartz, zircon and ilmenite suggesting $a_{\mathrm{SiO} 2}=1$ and $a_{\mathrm{TiO} 2}<1$. All

241 temperatures are uncorrected for $a_{\mathrm{TiO} 2}<1$, which in these systems we conservatively

242 estimate to be $\sim 0.6$ based on the presence of ilmenite and calculated $a_{\mathrm{TiO} 2}$ for similar

243 phase assemblages (Ghent and Stout, 1984). This would lead to underestimations of

244 zircon crystallization temperatures by $<50^{\circ} \mathrm{C}$ (Watson and Harrison, 2005). 
246 Following spot analyses, the mount was lightly polished to remove pits from Ti work,

247 then re-cleaned and re-coated with $\mathrm{Au}$ for U/Pb geochronology on SHRIMP RG at RSES.

248 The methods used are described in detail by Stern (1998) and Williams (1998) and are

249 summarized here. A $2.5 \mathrm{nA}$ primary beam was focused to a $20 \mu \mathrm{m}$ spot diameter and

250 positioned over sites of Ti analysis. A $120 \mu \mathrm{m}$ raster was programmed for $120 \mathrm{sec}$ to clean

251 the mount surface prior to data acquisition. FC1 zircon reference material was analysed

252 once every 3 unknowns. Data reduction was preformed using the Excel ${ }^{\mathrm{TM}}$ macro SQUID

253 (Ludwig, 2001). Zircon reference materials SL13 $(\mathrm{U}=238 \mathrm{ppm})$ and $\mathrm{FC} 1\left({ }^{206} \mathrm{~Pb} /{ }^{238} \mathrm{U}\right.$ age

$254=1099.0 \pm 0.5 \mathrm{Ma}$ ) were used for $\mathrm{U}$ abundance and ${ }^{206} \mathrm{~Pb} /{ }^{238} \mathrm{U}$ calibrations respectively.

256 The fifth Ti analytical session involved Ti imaging of selected grains. An ion microprobe

257 is the best tool suited to measure low ppm Ti levels in zircon, with maximum spatial

258 resolution. Imaging allows for determination of the origin of Ti variation as either

259 geologically significant temperature differences, or due to localized features and

260 imperfections such as edge effects, inclusions or cracks in the crystal structure.

261

262 Prior to imaging, the mounts were again lightly polished, re-cleaned and re-coated with

263 Au. Zircon grain maps were segmented into blocks to minimize the analytical time spent

264 off the grain and on surrounding epoxy. Each block was setup to run though a matrix with

265 automatic stage drive, primary and secondary tuning. Horizontal and vertical stage

266 movements were programmed to match the spot size so grain coverage was uniform and

267 maximized, without pit overlap or associated geometric effects. Instrumental setup was

268 identical to that described for spot analyses, except a 1.6nA $\mathrm{O}_{2}^{-}$primary beam was

269 focused to a $\sim 5 \mu \mathrm{m}$ spot, providing maximum spatial resolution without compromising

270 sensitivity. Prior to the start of data acquisition, a 120 second, $10 \mu \mathrm{m}$ pre-sputter burn-in

271 was programmed directly over the analysis area to clean it of Ti contamination, with

272 minimal disturbance to adjacent analytical sites, or to the sample's potential field defined

273 by the conductive coating. Data acquisitions for each spot consisted of 4, 10 second

274 integrations. 
276 No detectable impact to primary beam focusing or secondary ion yields was observed 277 with progressive removal of the Au layer, or due to the formation of topography on the

278 mount surface from material build-up from adjacent analytical pits. Ti concentrations and

279 temperatures were calculated with TiZer using SL13 zircon reference material analyses

280 separating blocks of unknowns. Concentration values were converted first to 2D matrices

281 and then to unsmoothed Ti intensity grain maps using "Intensity and 3D plot" written for

282 Lab VIEW by Peter Lanc.

284 New independent temperature estimates for sample G03/38 were determined by WDS

285 mineral analysis on a Camexa SX-51 electron microprobe at the Institute of Geology, the

286 Chinese Academy of Geological Sciences. The vicinity of analysed mineral assemblages

287 was imaged by backscattered electrons (BSE). Garnet-clinopyroxene Fe-Mg exchange

288 thermometry was calculated via the Ellis and Green (1979) calibration using the Excel ${ }^{\mathrm{TM}}$

289 spreadsheet PX-NOM of Sturm (2003).

292 4. Results

\section{4.1. Spot Analyses}

295 A summary of Ti thermometry and U-Pb dating results for G97/18 and G03/38 spot

296 analyses are presented in Table 1. Composite CL images with analysis locations,

297 crystallization temperatures and ${ }^{207} \mathrm{~Pb} /{ }^{206} \mathrm{~Pb}$ ages corrected for very small amounts of

298 common $\mathrm{Pb}$ (based on measured ${ }^{204} \mathrm{~Pb}$ ) are presented in Figures 4 and 5.

300 4.1.1. G97/18

301 Zircons from G97/18 are typically $\sim 200 \mu \mathrm{m}$ but upto $300 \mu \mathrm{m}$ in length and prismatic in

302 habit. Oscillatory zonation is fine, running parallel to grain boundaries and locally cut by

303 domains of recrystallization. Fourteen ${ }^{207} \mathrm{~Pb} /{ }^{206} \mathrm{~Pb}$ ages range from 3741 to $3833 \mathrm{Ma}$. Ten

304 analyses on oscillatory zoned zircon indicate ages of $>3800 \mathrm{Ma}$, while three of the four

305 analyses $<3800 \mathrm{Ma}$ are recrystallized domains. $36 \mathrm{Ti}$ spot analyses from 15 grains

306 yielded a range of crystallization temperatures from $631^{\circ} \mathrm{C}$ to $777^{\circ} \mathrm{C}$. The normal 
307 distribution is skewed towards its low temperature end, peaking from $660^{\circ} \mathrm{C}$ to $690^{\circ} \mathrm{C}$

308 and with a mean of $683 \pm 32^{\circ} \mathrm{C}, 1 \sigma$ (Figure $6 \mathrm{~A}$ ). Based on growth history identified by

309 oscillatory zonation the dataset consists of 9 grain core analyses (mean $=699 \pm 44^{\circ} \mathrm{C}, 1 \sigma$ ),

31021 mid grain analyses ( mean $=682 \pm 25^{\circ} \mathrm{C}, 1 \sigma$ ) and 6 grain edge analyses (mean $=$

$311662 \pm 19^{\circ} \mathrm{C}, 1 \sigma$ ). Five of the nine core analyses were made on recrystallized areas (mean $=$

$312677 \pm 33^{\circ} \mathrm{C}, 1 \sigma$ ) but typically show no indication of disturbance to Ti concentrations when

313 compared with adjacent analyses on the same crystal. Six grains received at least three

314 analyses and four grains were analysed twice. From these ten grains with multiple spots,

315 seven show expected systematic trends from apparently high temperature cores that

316 become cooler towards the grain edge; two grains show reverse patterns with lower

317 temperatures towards the grain interior, while one shows an oscillating temperature

318 profile from core to edge. Uncertainties from individual spot temperatures might be broad

319 enough to incorporate at least some of these apparent differences. Rim overgrowth

320 domains were deliberately avoided during these analyses. No systematic relationship

321 exists between Ti temperature and trace element variation as revealed by dark and light

$322 \mathrm{CL}$ domains. However, oscillatory zonation in these grains is particularly fine $(<5 \mu \mathrm{m})$,

323 and analysis by the $20 \mu \mathrm{m}$ beam would potentially average micrometer scale

324 compositional variations. Similarly no association can be made between temperature and

325 recrystallised domains, $\mathrm{U}$ concentration, Th concentration, $\mathrm{U} / \mathrm{Th}$ ratio, ${ }^{204} \mathrm{~Pb}$ corrected

$326{ }^{207} \mathrm{~Pb} /{ }^{206} \mathrm{~Pb}$ age or discordance.

4.1.2. $\mathrm{G03} / 38$

329 Zircons from G03/38 are dominantly $\sim 100 \mu \mathrm{m}$ but upto $200 \mu \mathrm{m}$ in length and typically

330 oval to equant in shape. Most display turbid or sector zonation while smaller components

331 are bright and structureless, or show oscillatory zonation. Eleven ${ }^{207} \mathrm{~Pb} /{ }^{206} \mathrm{~Pb}$ ages range

332 from 2666 to $2756 \mathrm{Ma}$, eight analyses are associated with the recognized $2714 \pm 4 \mathrm{Ma}$

333 peak and three with the minor $2690 \pm 6$ Ma peak. Fourteen Ti analyses from eleven grains

334 yielded a narrow range of crystallization temperatures from $660^{\circ} \mathrm{C}$ to $697^{\circ} \mathrm{C}$, with a mean

335 of $679^{\circ} \mathrm{C} \pm 11^{\circ} \mathrm{C}, 1 \sigma$ (Figure $6 \mathrm{~B}$ ). Again no correlation between Ti concentration or

336 temperature and $\mathrm{CL}$, degree of recrystallisation, $\mathrm{U}, \mathrm{Th}, \mathrm{U} / \mathrm{Th},{ }^{204} \mathrm{~Pb}$ corrected ${ }^{207} \mathrm{~Pb} /{ }^{206} \mathrm{~Pb}$

337 or discordance exists. 
339 Results from G03/38 garnet-clinopyroxene mineral analyses are presented in Table 2.

340 Garnet + clinopyroxene + plagioclase + quartz domains display minor alteration by

341 retrogressive reactions, and ilmenite is the main Ti-bearing phase (Figure 2). Within the

342 garnets are well preserved clinopyroxene inclusions, whose edges are unaffected by

343 retrogressive amphibole-forming reactions. Along the edges of garnets are coronas of

344 hornblende + plagioclase, locally as narrow as $100 \mu \mathrm{m}$. The main garnet + clinopyroxene

$345+$ plagioclase (An41-42) + quartz assemblage is interpreted to be coeval with the felsic

346 segregation observed in outcrop. This segregation was the source of the zircon used for

347 Ti-in-zircon thermometry.

349 Garnet-clinopyroxene pairs C and D from the grain interiors (Figure 2) yield

350 temperatures of $700-730^{\circ} \mathrm{C}$ (between 6 and $10 \mathrm{kbar}$ ). Garnet-clinopyroxene pairs A (at the

351 margin of unaltered clinopyroxene within garnet) and B (separated by a $100 \mu \mathrm{m}$

352 hornblende + An45-45 plagioclase corona) give lower temperatures of $590-630^{\circ} \mathrm{C}$

353 (between 6 and $10 \mathrm{kbar}$ ).

\subsection{Grain Matrix Mapping}

357 Titanium intensity grain maps were produced on grains G97/18-2, G97/18-11 and FC1-7

358 in order to investigate the details of Ti distribution within single oscillatory zoned grains.

359 Grains from G97/18 were targeted as they emerged with significant Ti variability during

360 spot analyses. FC1-7 was selected to look for an association between large, distinct CL

361 brightness domains and Ti concentrations. The tabulated results are presented in

362 Background Dataset 2.

\subsubsection{G97/18-2}

365 Four spot analyses on grain G97/18-2 (Figure 4, Table 1) presented the largest variation 366 of Ti concentration ( 2.5 to $14.9 \mathrm{ppm}$ ) and crystallization temperature (631 to $\left.777^{\circ} \mathrm{C}\right)$. The

367 distribution of spot concentrations indicates temperatures are highest at the core and 
368 become lower towards both tips. Hence this grain may provide the best thermal

369 representation of G97/18 zircon growth in the history of one single crystal.

371 The Ti intensity map for G97/18-2 is presented in Figure 7A with associated reflected

372 light, transmitted light and CL images. The grain appears pristine, free of any cracks or

373 inclusions and to have experienced a smooth, uninhibited growth. Its concentration

374 profile demonstrates a systematic decline in Ti from core to rim with mutually consistent

375 values where spot analyses would overlap. This provides a valuable internal check on the

376 validity of measurements made under different analytical approaches during different

377 sessions. The unsmoothed grain image is constructed of 431 pixels, excluding the 0.0

378 ppm background. Each pixel represents an independent SHRIMP analysis which yielded

379 concentrations ranging from to $2.0 \mathrm{ppm}\left(617^{\circ} \mathrm{C}\right)$ to $572.5 \mathrm{ppm}\left(1289^{\circ} \mathrm{C}\right)$. Of these 431

380 analyses, 59 recorded concentrations $>15.0 \mathrm{ppm}(16$ of these $>100.0 \mathrm{ppm})$ and are

381 irregularly concentrated around the grain's extreme rim. Rim overgrowth domains were

382 avoided during spot analyses, subsequently these high and variable concentrations feature

383 as an unexpected result in the grain matrix map. The figure was constructed with the $\mathrm{Ti}$

384 concentration range capped at $15.0 \mathrm{ppm}$ to highlight the grain's internal variability from

385 core to mid regions rather than extreme concentrations on the grain edge. This limit

386 corresponds to the maximum concentrations measured in the grain's core and represents a

387 crystallization temperature of approximately $778^{\circ} \mathrm{C}$.

389 Ti crystallization temperatures derived from G97/18-2 are presented in Figure 6C. The

390 profile consists of 372 analyses with concentrations from $2.0 \mathrm{ppm}\left(617^{\circ} \mathrm{C}\right)$ to $15.0 \mathrm{ppm}$

$391\left(778^{\circ} \mathrm{C}\right)$. The normal distribution is relatively smooth, uninterrupted, and skewed towards

392 lower temperatures, with a mean of $676 \pm 40^{\circ} \mathrm{C}(1 \sigma)$. Again temperatures associated with

393 rim concentrations $>15.0 \mathrm{ppm}$ were filtered from the image. Figure 8 has been added to

394 represent a revised version of the Ti intensity map if $>15.0 \mathrm{ppm}$ pixels are excluded. Here

395 the grain appears with a more uniform edge and better resembling morphology from

396 reflected, transmitted and CL imaging.

\subsubsection{G97/18-11}


399 Five spot analyses on grain G97/18-11 revealed complex and unsystematic distributions

400 of Ti concentrations (range of 3.5 to $13.6 \mathrm{ppm}$ ) and crystallization temperatures (range of

401656 to $768^{\circ} \mathrm{C}$ ) that undulate on a transect from the grain core to tip, following oscillatory

402 growth domains identified in CL imaging. Absolute uncertainties on analytical spots

403 provide inadequate overlap to explain these differences.

The Ti intensity map for G97/18-11 is presented in Figure 7B. Orientation has been

406 rotated clockwise $\sim 45^{\circ}$ with respect to the grain as presented in Figure 4 . Reflected and

407 transmitted light imaging reveal an inclusion and cracks that meet the polished surface.

408 CL imaging makes clear the large recrystallised core and small opaque inclusion within

409 large oscillatory zoned domains. The image is made of 583 pixels of concentrations

410 ranging from $2.0 \mathrm{ppm}\left(616^{\circ} \mathrm{C}\right)$ to $68125.4 \mathrm{ppm}\left(4044^{\circ} \mathrm{C}\right)$. Of the 583 analyses, 100

411 recorded concentrations $>15.0 \mathrm{ppm}$ with $25>100.0 \mathrm{ppm}$. Ti concentrations are again

412 consistent with values from spot analyses where overlapping. The figure concentration

413 range was similarly capped at $15.0 \mathrm{ppm}$ to provide clarity to the image. Highest values

414 are again irregularly distributed around the grain's extreme rim and also penetrate the

415 grain edge with anomalously large excursions occurring near the cracks and inclusion.

416 The distribution of $\mathrm{Ti}$ is complex but shows no indication of disturbance in the large

417 recrystallized core that appears as a uniform thermo-chemical domain. In the vicinity of

418 the earlier spot analysis transect, Ti concentrations from pristine zircon appear to display

419 a transient oscillation between approximately 3.0-8.0 ppm.

421 Crystallization temperatures from G97/18-11 are presented in Figure 6D from 483

422 analyses of concentrations ranging from $2.0 \mathrm{ppm}\left(616^{\circ} \mathrm{C}\right)$ to $14.6 \mathrm{ppm}\left(775^{\circ} \mathrm{C}\right)$. The

423 distribution is normal with a locus at the mean of $691 \pm 26^{\circ} \mathrm{C}(1 \sigma)$. Temperatures

424 associated with concentrations $>15.0 \mathrm{ppm}$ were again removed from the profile.

426 4.2.3. FC1-7

427 No spot analysis was previously performed on grain FC1-7. It was analysed to firstly look

428 for relationship between Ti distribution and spatially resolvable CL domains, and

429 secondly to test if high Ti rims were a unique feature to grains from sample G97/18. The 
430 Ti intensity map for FC1-7 is presented in Figure 7C. The crystal appears pristine, free of 431 any cracks or inclusions. Its concentration profile demonstrates a gradient in Ti from one

432 side to the other but can not be clearly associated with the tone of CL domains. The

433 image comprises 156 pixels with concentrations ranging from 7.9 ppm to $240.7 \mathrm{ppm} .19$

434 analyses recorded concentrations $>15.0 \mathrm{ppm}$, with $11>100.0 \mathrm{ppm}$. The highest Ti

435 concentrations are irregularly distributed along the length of the higher concentration side

436 of the crystal. The figure concentration range was capped at $50.0 \mathrm{ppm}$ for clarity.

\section{4.3. Origin of high Ti rims}

439 To further pursue the origin of the very high Ti rims observed on G97/18-2, G97/18-11

440 and FC1-7, whole zircons from G97/18, G03/38, SL13, FC1 and Temora-2 were depth

441 profiled using LA-ICPMS. Crystals were placed onto a glass slide with double sided

442 adhesive tape and flattened onto their c-axis. Grains were again protected from airborne

443 contamination by the adhesive tape's paper spacer when not inside the LA-ICPMS

444 sample cell or being photographed. Analytical methods were identical to those described

445 above for the reference material calibration except that acquisitions consisted of

446 collection periods of upto 360 seconds to try and penetrate the grains entire thickness.

447 Drilling started from the top surface, and generally passed through the entire grain, the

448 bottom surface, adhesive tape and into the glass slide. Results are presented in Table 3.

449 Grains from every aliquot recorded a marked increase in Ti concentrations on most top

450 and bottom surfaces (Figure 9A). Of the 77 surfaces analysed from 51 grains of G97/18,

$45186 \%$ showed anomalously high Ti concentrations, $90 \%$ of the 10 surfaces on 5 grains of

452 G03/38 showed excursions, 53\% of the 32 surfaces on 15 grains of SL13 showed

453 excursions, $68 \%$ of the 53 surfaces on 32 grains of FC1 showed excursions, $85 \%$ of the

45427 surfaces on 17 grains of Temora-2 showed excursions. Anomalous Ti values could

455 often be detected within the crystal structure during laser drilling but these probably

456 represent analysis of ilmenite inclusions.

458 SL13 crystals are broken fragments from a larger zircon megacryst. As such their

459 surfaces are modern features. This suggests that the apparent high Ti rims are an artifact

460 of sample processing rather intrinsic features. To test this, further aliquots of the Temora- 
2 reference material were variously subjected to either: (1) air abrasion with pyrite

462 crystals to remove the grain exteriors; (2) HF partial dissolution with $1: 1 \mathrm{HF}-\mathrm{HCl}$ in a

463 sealed teflon beaker for 24 hours on a $120^{\circ} \mathrm{C}$ hotplate; (3) repeated acetone, or (4) ethanol

464 rinses with an ultrasonic bath followed by decanting. The aim of this exercise was to

465 remove any surface contamination originating from magmatic chemical disequilibrium,

466 minor phases, residues from sample crushing or milling, heavy liquids or other aspect of

467 sample processing that may resulted in high Ti. Results are presented in Table 3. High Ti

468 rims were still widely observed (on $83 \%$ to $100 \%$ of analysed surfaces) from all treated

469 aliquots suggesting none of these contamination processes are the cause of this effect.

471 In a last attempt to understand the origin of these signatures direct analysis of the glass

472 slide, epoxy and adhesive tape used to hold the grains was made. While glass and epoxy

473 produced no anomalies, high Ti excursions from the adhesive tape provided identical

474 enrichment profiles to the grain surfaces (Figure 9B), making this contact medium the

475 favored cause for the excursions. It appears ${ }^{49} \mathrm{Ti}$ (or a molecular isobar) can unevenly mix

476 from the adhesive tape into the adjacent epoxy during mount casting, and also be

477 transferred to the grain's top surface by contact with the adhesive tape's paper spacer,

478 which is commonly placed on top of the zircons to protect them at various times during

479 mount preparation. The Ti signature of the tape may be an organic molecule that is

480 unresolved from ${ }^{49} \mathrm{Ti}$ in the SHRIMP even at the $\sim 5000$ mass resolution used during

481 analysis. However, it is noted that similar features have been seen on zircon exteriors by

482 other workers when measuring ${ }^{48} \mathrm{Ti}$ (Harrison and Schmitt, 2007). These features have in

483 some cases been attributed to extreme high temperature geologic events (Trail et al., 484 2006).

\section{Discussion}

\subsection{Temperatures from zircons of metamorphic rock $G 03 / 38$}

490 The G03/38 Ti-in-zircon temperatures of $679 \pm 11^{\circ} \mathrm{C}(1 \sigma)$ are based on a calibration that

491 assumes rutile as the Ti-buffering phase. Because the main Ti-bearing phase in G03/38 is 
492 ilmenite the calibration may underestimate the calculated G03/38 zircon temperatures by

493 up to $50^{\circ} \mathrm{C}$. With this consideration there is a reasonable agreement between the Ellis and

494 Green (1979) garnet-clinopyroxene Fe-Mg exchange thermometer $\left(700-730^{\circ} \mathrm{C}\right)$ and the

495 Ti-in-zircon thermometer for this sample. Garnet-clinopyroxene pairs A and B give

496 lower temperatures $\left(590-630^{\circ} \mathrm{C}\right)$ probably reflecting conditions during superimposed

497 hydration reactions. These results indicate that well equilibrated metamorphic zircon,

498 which forms over a relatively narrow time interval is capable of yielding precise Ti

499 crystallization temperatures that are relatively consistent with established thermometers,

500 although this will require accurate knowledge of $a_{\mathrm{TiO} 2}$ for the given system. It suggests

501 the method could be a useful tool for determining (possibly multiple) metamorphic

502 conditions in complicated rocks.

\subsection{Ti thermometry of 3.81 Ga meta-tonalite G97/18}

Magmatic temperatures expected during formation of tonalitic melt compositions have

507 been constrained by extensive experimental data at above $1000^{\circ} \mathrm{C}$ (Rapp and Watson,

508 1995), classifying such lithologies as "hot" granites. Sample G97/18 is free of inherited

509 zircon and has a $\mathrm{Zr}$ abundance of $121 \mathrm{ppm}$ (Nutman et al., 1999). Using the zirconium

510 saturation in melts relationship of Watson and Harrison (1983) as a guide, G97/18 should

511 become saturated in zircon at $\sim 729^{\circ} \mathrm{C}$, hence zircon should crystallize as a late phase

512 from a residual melt at temperatures significantly less than that of the parental liquidus

513 (cf. Nutman, 2006). Modeling has been used to predict the expected distribution of zircon

514 formation as a function of temperature during cooling of a similar intermediate plutonic

515 system (Harrison and Watson, 2006; Figure 3 in Harrison et al. 2007). These calculations

516 predict the distribution would exist as a broad spectrum, with zircon growth declining

517 away from its high temperature end.

519 The maximum Ti-in-zircon temperatures from G97/18 tonalite (reaching $777 \pm 14^{\circ} \mathrm{C}$ ) are

520 notably higher than those expected from zircon saturation thermometry. However the

521 majority of temperatures (mean of $683 \pm 32^{\circ} \mathrm{C}, 1 \sigma$ ), reinforced by detailed mapping of

522 grains $\mathrm{G} 97 / 18-2\left(676 \pm 40^{\circ} \mathrm{C}\right)$ and $\mathrm{G} 97 / 18-11\left(691 \pm 26^{\circ} \mathrm{C}\right)$ are significantly lower. These 
523 temperatures and distributions are identical, within errors, to those associated with wet,

524 minimum melt, low temperature granites (Watson and Harrison, 2005). The form of these

525 temperature distributions may reflect real gradients for natural zircon formation in similar

526 plutonic systems over protracted retrograde intervals.

528 The dataset is not biased by lack of high temperature analyses from any specific crystal

529 domains (such as cores) as we have analyzed entire grain mid-sections. Given a plausible

$530 a_{\mathrm{TiO} 2}$ for this igneous system of $\sim 0.6$, corrections for subunity $a_{\mathrm{TiO} 2}$ would lead to upward

531 temperature adjustments of $<50^{\circ} \mathrm{C}$, however, the $a_{\mathrm{TiO} 2}$ of individual detrital zircons can

532 not be precisely known. Subsequently, analysis of Eoarchaean detrital zircons derived

533 from a tonalite such as G97/18 would present a low temperature biased image for their

534 magma source and perhaps lead to the erroneous interpretation of their origin in a

535 minimum melt, low temperature granite.

537 In some grains the distribution of $\mathrm{Ti}$ can be correlated to core and rim domains identified

538 by grain imaging. Trends of Ti variation are consistent with processes of magma cooling

539 (such as in grain G97/18-2) and less frequently as magma recharge or grain convection

540 (in grain G97/18-11). However, during a recharge scenario the introduction of hot, $\mathrm{Zr}$

541 undersaturated melt in the presence of late-crystallizing zircons would be likely to

542 partially or entirely dissolve existing grains (Watson, 1996; Nutman et al., 1999; Mojzsis

543 and Harrison, 2002). No indication of dissolution is found on any crystal. Hence a

544 favored alternative interpretation to the oscillating Ti variations seen in G97/18-11 relates

545 to local disequilibrium in trace element partitioning at the zircon/melt interface (Hoskin, 546 2000).

\section{Conclusions}

551 The Ti-in-zircon thermometer can provide precise temperature estimates in well-

552 equilibrated high grade metamorphic systems. However the accuracy will depend on 
553 accurate knowledge of the $a_{\mathrm{TiO} 2}$. Large igneous systems such as those that produce 554 tonalites, undersaturated in $\mathrm{Zr}$ and with $a_{\mathrm{TiO} 2}<1$, produce low apparent Ti-in-zircon 555 temperatures and distributions that may accurately record the crystallization temperatures

556 of zircon, but likely underestimate that of the parental melt. An inference from this study

557 is that detrital zircons from a rock like tonalite G97/18 would yield low temperature

558 distributions, which could lead to an erroneous interpretation of the lithology from which

559 these zircons were eroded. Thus, there is an inability to distinguish with confidence,

560 using only Ti thermometry, zircons grown in granitic magmas generated by "hot" (900-

$\left.5611000^{\circ} \mathrm{C}\right)$ and "cool" $\left(650-750^{\circ} \mathrm{C}\right)$ melting. Furthermore individual zircons from large

562 magma chambers can yield complex Ti temperature distributions reflecting variable

563 cooling histories and local chemical environments. Apparent extreme $\left(>1000^{\circ} \mathrm{C}\right) \mathrm{Ti}$-in-

564 zircon temperatures derived from zircon rims of samples and reference materials are an

565 artifact of sample preparation. Our study monitoring mass ${ }^{49} \mathrm{Ti}$ has traced the origin of

566 excess Ti to a contaminant in the double sided adhesive tape on which zircons are held

567 prior to casting in epoxy mounts, or on which they are held during laser ablation ICP-MS

568 depth-profiling. Caution in assigning geologic meaning to temperatures from near grain

569 surfaces as well as inclusions and cracks is emphasized.

\section{Acknowledgments}

574 Sample G97/18 was collected during Greenland fieldwork funded by the Research School 575 of Earth Sciences (ANU). In this respect, we wish to thank Prof. David Green. Collection

576 of sample G03/38 and all analytical work was supported by the Australian Research

577 Council grants DP0342798 and DP0342794. Analytical work was undertaken while Hiess

578 was a PhD student at ANU supported by APA and Jaeger scholarships. We thank Shane

579 Paxton and Jon Mya for zircon separations; Chuck McGee for technical assistance with

580 LA-ICPMS analysis; Amos Aikman, Antti Kallio and Peter Lanc for providing software

581 and advice in data processing; Trevor Ireland, Ian Williams, Joerg Herman and Charlotte

582 Allen for helpful discussions. The manuscript was improved by helpful reviews from

583 Laurence Coogan and Paul Hoskin. 


\section{References}

588 Aikman, A., 2007. Tectonics of the eastern Tethyan Himalaya. Unpublished Ph.D.

589 Thesis, RSES, ANU, Canberra, ACT, Australia.

591 Black, L.P., Kamo, S.L., Allen, C.M., Aleinikoff, J.N., Davis, D.W., Korsch, R.J.,

592 Foudoulis, C., 2003. TEMORA 1: a new zircon standard for phanerozoic U-Pb

593 geochronology. Chemical Geology 200, 155-170.

595 Chadwick, B., Nutman, A.P., 1979. Archaean structural evolution in the northwest of the 596 Buksefjorden Region, southern West Greenland. Precambrian Research 9, 199-226.

598 Cherniak, D.J., Watson, E.B., 2007. Ti Diffusion in zircon. Chemical Geology 242, 470599483.

601 Claoué-Long, J.C., Compston, W., Roberts, J., Fanning, C.M., 1995. Two Carboniferous 602 ages: a comparison of SHRIMP zircon dating with conventional zircon ages and $603{ }^{40} \mathrm{Ar} /{ }^{39} \mathrm{Ar}$ analysis. In: Berggren, W.A., Kent, D.V., Aubry, M.P., Hardenbol, J., (Eds.), 604 Geochronology, Time Scales and Global Stratigraphic Correlation. SEPM Special 605 Publication 54, 3-21.

607 Coogan, L.A., Hinton, R.W., 2006. Do the trace element compositions of detrital zircons 608 require Hadean continental crust? Geology 34, 633-636.

610 Crowley, J.L., 2003. U-Pb geochronology of 3810-3630 Ma granitoid rocks south of the

611 Isua greenstone belt, southern West Greenland. Precambrian Research 126, 235-257. 
613 Eggins, S., Rudnick, R.L., McDonough, W.F., 1998. The composition of peridotites and 614 their minerals: a laser ablation ICP-MS study. Earth and Planetary Science Letters 154, $615 \quad 53-71$.

616

617 Ellis, D.J., Green, D.H., 1979. An experimental study of the effects of Ca on garnet618 clinopyroxene Fe-Mg exchange equilibria. Contributions to Mineralogy and Petrology $61971,13-22$.

620

621 Ghent, E.D., Stout, M.Z., 1984. TiO2 activity in metamorphosed pelitic and basic rocks:

622 principles and applications to metamorphism in southeastern Canadian Cordillera.

623 Contributions to Mineralogy and Petrology 86, 248-255.

Harrison, M., Watson, B., 2006. Interpretation of Ti-in-zircon Thermometery in Plutonic 626 Rocks, Eos Trans. AGU, 87, V31F-03.

628 Harrison, T.M., Schmitt, A.K., 2007. High sensitivity mapping of Ti distributions in 629 Hadean zircons. Earth and Planetary Science Letters 261, 9-19.

631 Harrison, T.M., Watson, E.B., Aikman, A.B., 2007. Temperature spectra of zircon 632 crystallization in plutonic rocks. Geology 35, 635-638.

634 Honda, M., Nutman, A.P., Bennett, V.C., 2003. Xenon compositions of magmatic zircons 635 in 3.64 and 3.81 Ga meta-granitoids from Greenland; a search for extinct ${ }^{244} \mathrm{Pu}$ in ancient 636 terrestrial rocks. Earth and Planetary Science Letters 207, 69-82.

638 Hoskin, P.W.O., 2000. Patterns of chaos: Fractal statistics and the oscillatory chemistry 639 of zircon. Geochimica et Cosmochimica Acta 64, 1905-1923.

641 Ludwig, K.R., 2001. Squid 1.02 User’s Manual, Berkley Geochronology Centre Special 642 Publication No. 2., Rev. June 20. 19p. 
644 Mojzsis, S.J., Harrison, T.M., 2002. Establishment of a 3.83-Ga magmatic age for the

645 Akilia tonalite (southern West Greenland). Earth and Planetary Science Letters 202, 563-

646576.

647

648 Nutman, A.P., 2006. Comment on "Zircon Thermometer Reveals Minimum Melting

649 Conditions on Earliest Earth". Science 311, 779b.

650

651 Nutman, A.P., Friend, C.R.L., 2007. Adjacent terranes with ca. 2715 and 2650 Ma high-

652 pressure metamorphic assemblages in the Nuuk region of the North Atlantic Craton,

653 southern West Greenland: Complexities of Neoarchaean collisional orogeny.

654 Precambrian Research 155, 159-203.

655

656 Nutman, A.P., Friend, C.R.L., Baadsgaard, H., McGregor, V.R., 1989. Evolution and

657 assembly of Archean gneiss terranes in the Godthåbsfjord region, southern west

658 Greenland: structural, metamorphic and isotopic evidence. Tectonics 8, 573-589.

659

660 Nutman, A.P., McGregor, V.R., Friend, C.R.L., Bennett, V.C., Kinny, P.D., 1996. The

661 Itsaq gneiss complex of southern West Greenland; the world's most extensive record of

662 early crustal evolution (3900-3600 Ma). Precambrian Research 78, 1-39.

664 Nutman, A.P., Bennett, V.C., Friend, C.R.L., Norman, M.D., 1999. Meta-igneous (non-

665 gneissic) tonalites and quartzdiorites from an extensive ca. $3800 \mathrm{Ma}$ terrain south of the

666 Isua supracrustal belt, southern West Greenland; constraints on early crust formation.

667 Contributions to Mineralogy and Petrology 137, 364-388.

668

669 Paces, J.B., Miller, J.D., 1993. Precise U-Pb age of Duluth Complex and related mafic

670 intrusions, northeastern Minnesota: Geochronological insights to physical, petrogenetic,

671 paleomagnetic, and tectonomagnetic processes associated with the $1.1 \mathrm{Ga}$ midcontinent

672 rift system. Journal of Geophysical Research 98, 13997-14013. 
674 Pearce, N., Perkins, J., Westgate, J., Gorton, M., Jackson, S., Neal, C., Chenery, S., 1997.

675 A compilation of new and published major and trace element data for NIST SRM 610

676 and NIST SRM 612 glass reference materials. Geostandards Newsletter 21, 115-144.

678 Rapp, R.P., Watson, E.B., 1995. Dehydration Melting of Metabasalt at

679 8-32 kbar: Implications for Continental Growth and Crust-Mantle Recycling. Journal of

680 Petrology 36, 891-931.

682 Sambridge, M.S, Compston, W., 1994. Mixture modelling of multicomponent data sets

683 with application to ion-probe zircon ages. Earth and Planetary Science Letters 128, $373-$ 684390.

686 Stern, R.A., Bleeker, W., 1998. Age of the world's oldest rocks refined using Canada's

687 SHRIMP: the Acasta Gneiss Complex, Northwest Territories, Canada. Geoscience

688 Canada 25, 27-31.

689

690 Sturm, R., 2003. PX-NOM - an interactive spreadsheet program for the computation of

691 pyroxene analyses derived from the electron microprobe. Computers and Geosciences, $692 \quad 28,473-483$.

693

694 Trail, D., Mojzsis, S.J., Harrison, T.M., Levison, H.F., 2006. Do Hadean zircons retain a 695 record of the late heavy bombardment on Earth? Lunar and Planetary Science Conference 696 XXXVII, 2139 Houston, Texas.

698 Valley, J.W., Cavosie, A.J., Fu, B., Peck, W.H., Wilde, S.A., 2006. Comment on

699 "Heterogeneous Hadean Hafnium: Evidence of Continental Crust at 4.4 to $4.5 \mathrm{Ga}$,,

700 Science 312, 1139a.

701

702 Watson, E.B., 1996. Dissolution, growth and survival of zircons during crustal fusion;

703 kinetic principles, geological models and implications for isotopic inheritance. Special

704 Paper of the Geological Society of America 315, 43-56. 
706 Watson, E.B., Harrison, T.M., 1983. Zircon saturation revisited: temperature and

707 composition effects in a variety of crustal magma types. Earth and Planetary Science

708 Letters 64, 295-304.

709

710 Watson, E.B., Harrison, T.M., 2005. Zircon thermometer reveals minimum melting

711 conditions on earliest Earth. Science 308, 841-844.

712

713 Watson, E.B., Harrison, T.M., 2006. Response to Comments on "Zircon Thermometer

714 Reveals Minimum Melting Conditions on Earliest Earth". Science 311, 779c.

716 Watson, E.B., Wark, D., Thomas, J., 2006. Crystallization thermometers for zircon and

717 rutile. Contributions to Mineralogy and Petrology 151, 413-433.

718

719 Williams, I.S., 1998. U-Th-Pb geochronology by ion microprobe. Reviews in Economic

720 Geology 7, 1-35.

721

722 Wyllie, P.J., Wolf, M.B., 1993. Amphibolite-dehydration melting: sorting out the solidus.

723 In: Pritchard, H.M., Alabaster, T., Harris, N.B.W., Neary, C.R., (Eds.) Magmatic

724 Processes and Plate Tectonics. Geological Society Special Paper 76, 405-416.

725

726

\section{Figure Captions}

729 Figure 1.

730 Cathodoluminesence (CL) and transmitted light (trans) images of fine oscillatory zoned

731 G97/18 grain with exposed ilmenite (ilm) inclusion.

732

733 Figure 2.

734 Backscattered electron image of G03/38 high pressure assemblage with well preserved

735 garnet $(g n t)+$ clinopyroxene $(\mathrm{cpx})+$ plagioclase $(\mathrm{plag})+$ quartz $(\mathrm{qtz})$ equilibrium 
736 boundaries. Retrogression to hornblende (hbl) is minimal. A, B, C and D indicate

737 locations of garnet and clinopyroxene WDS mineral analysis.

739 Figure 3.

740 Zircon calibration and reference material data A) SHRIMP ${ }^{49} \mathrm{Ti} / \mathrm{SiO}$ vs LA-ICPMS [Ti]

741 linear relationship from SL13, Temora-2 and FC1 reference materials. Point and zero

742 calibration line passes from the origin through the mean of SL13 values; B) SHRIMP

$743{ }^{49} \mathrm{Ti} / \mathrm{SiO}$ with TiZer calculated [Ti] for unknowns and related reference materials from

744 sessions 1-4; C) As B) for session 5; D) Summary of Ti concentrations from 64 analyses

745 of SL13 over all sessions. Mean $=6.14 \pm 0.02 \mathrm{ppm}(2 \sigma)$.

747 Figure 4.

748 Composite CL image for G97/18 sample zircons with analysis spots, uncorrected

749 crystallization temperatures and ${ }^{207} \mathrm{~Pb} /{ }^{206} \mathrm{~Pb}$ ages. Grains $\mathrm{G} 97 / 18-2$ and $\mathrm{G} 97 / 18-11$ reveal

750 complex temperature profiles targeted for Ti matrix mapping.

752 Figure 5.

753 Composite CL image with analysis spots, uncorrected crystallization temperatures and

$754{ }^{207} \mathrm{~Pb} /{ }^{206} \mathrm{~Pb}$ ages for zircon of sample G03/38. Note the narrow range of crystallization

755 temperatures for this simple closed system.

757 Figure 6.

758 Histogram and probability density plots of uncorrected crystallization temperatures for A) 759 spot analysis of sample G97/18, B) spot analysis of sample G03/38, C) mapping of single 760 grain G97/18-2, D) mapping of single grain G97/18-11. Temperatures associated with $\mathrm{Ti}$ 761 concentrations $>15.0 \mathrm{ppm}\left(>778^{\circ} \mathrm{C}\right)$ and $>14.6 \mathrm{ppm}\left(>775^{\circ} \mathrm{C}\right)$ filtered from figures $\mathrm{C}$ and 762 D respectively.

764 Figure 7.

765 From left to right: reflected light, transmitted light, CL images and Ti concentration maps 766 for grains A) G97/18-2, length of crystal $200 \mu \mathrm{m}$, note highest concentrations observed in 
Figure 2

Click here to download high resolution image

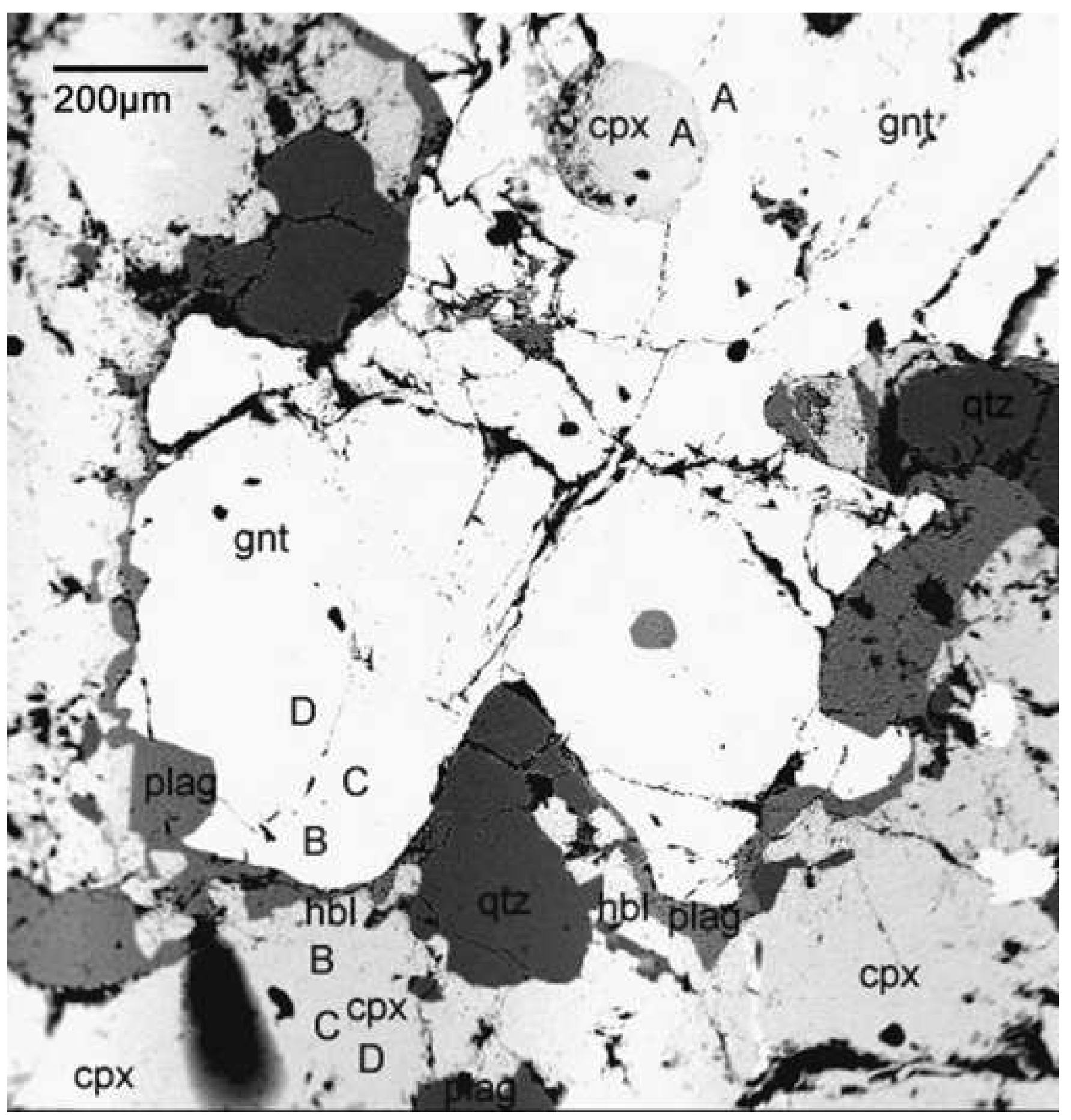




\section{Figure 3}

Click here to download high resolution image

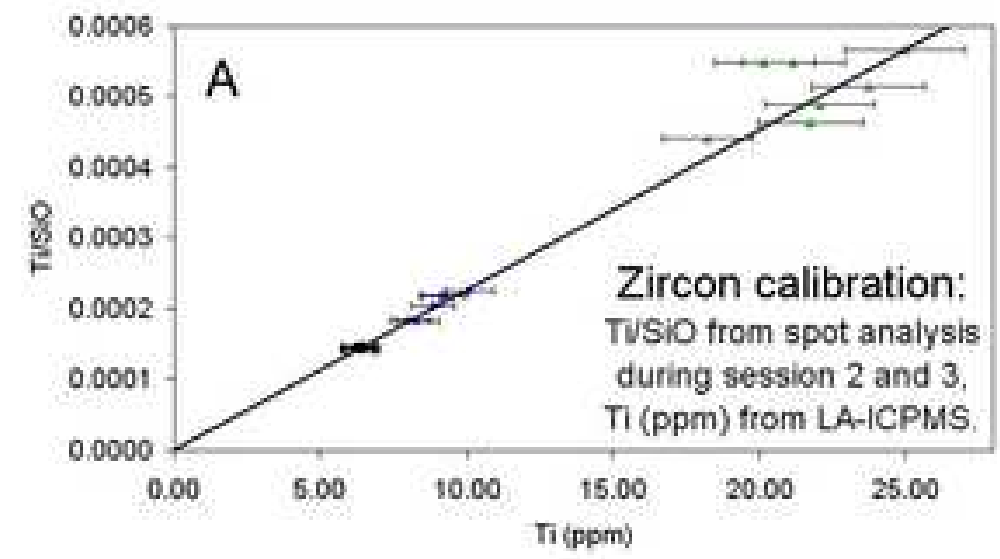

- SL13 $(n=10)$ - Temora-2 $(n=6)$. FCI $(n=7)-S L 13$ Calbration

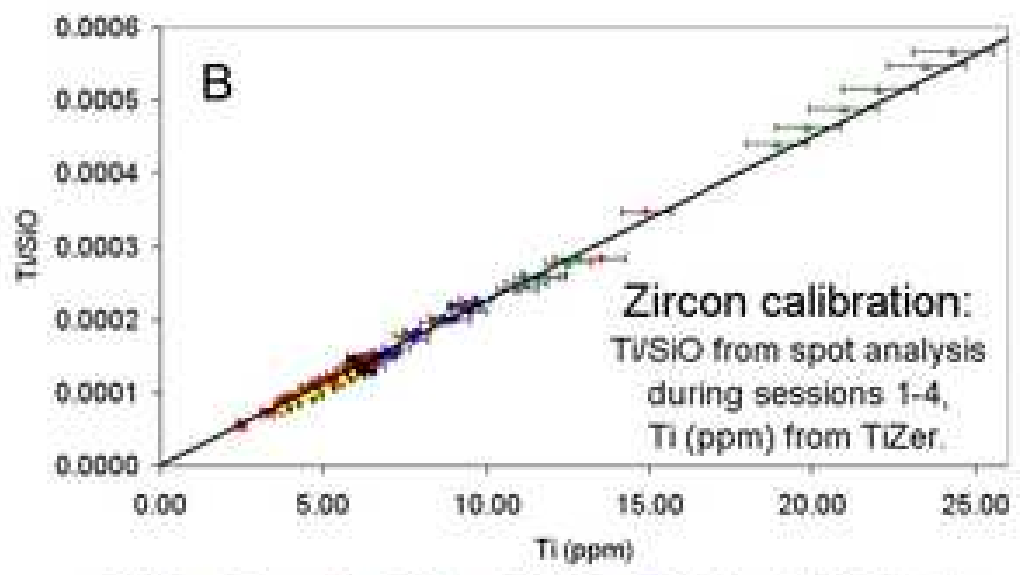

- SL13 - Temora-2 + FC1 * G9718 G03/38 - SL13 Calloration

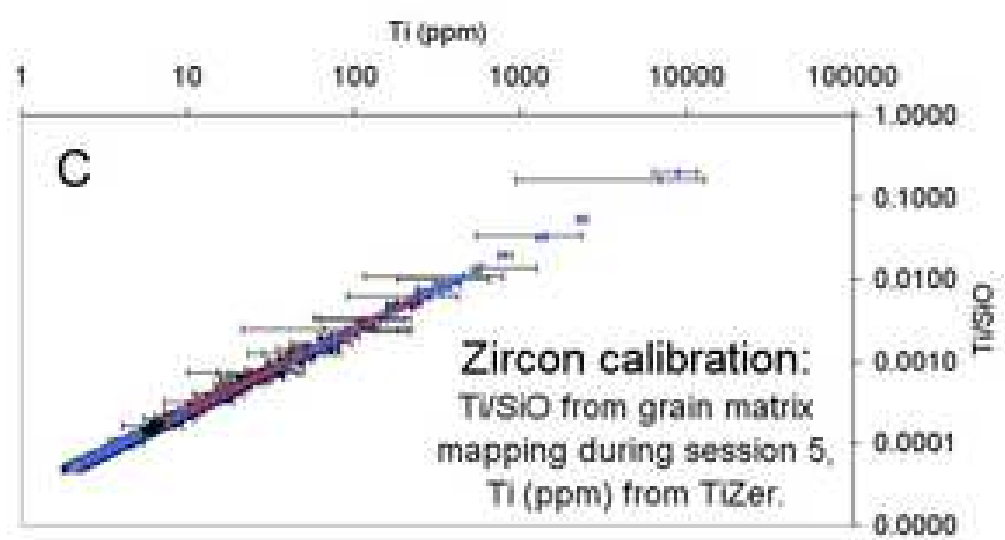

$\cdot 697 / 18-2+697 / 18-11+\mathrm{FCl}-7 \cdot \mathrm{SL} 13$

D SL13 zircon reference material

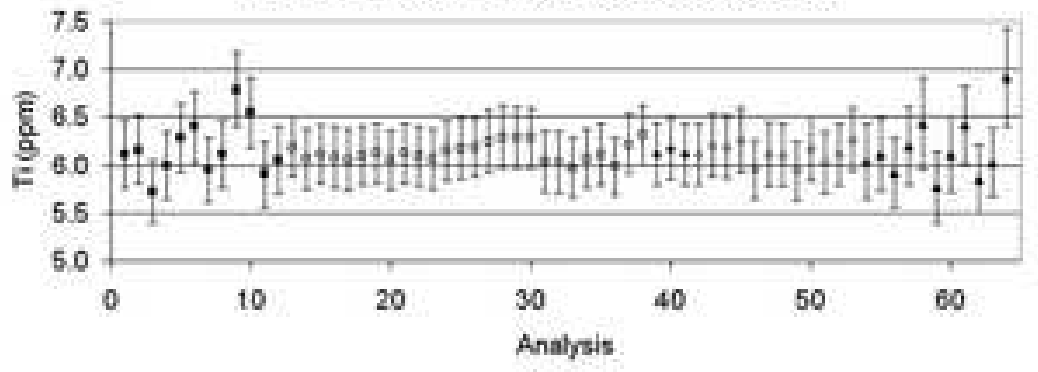

- Session $1+$ Sestion $2 \cdot$ Sestion 3 - Session $4 \cdot$ Session 5 


\section{Figure 5
Click here to download high resolution image}

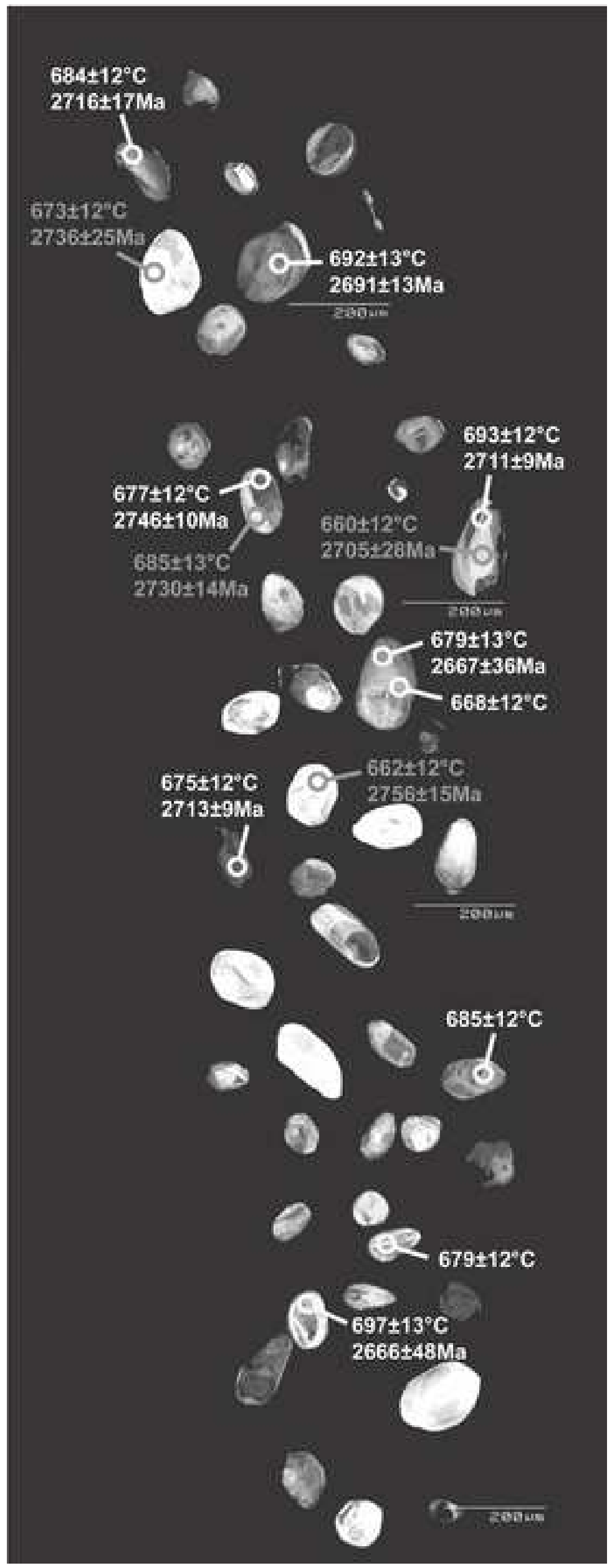


Click here to download high resolution image
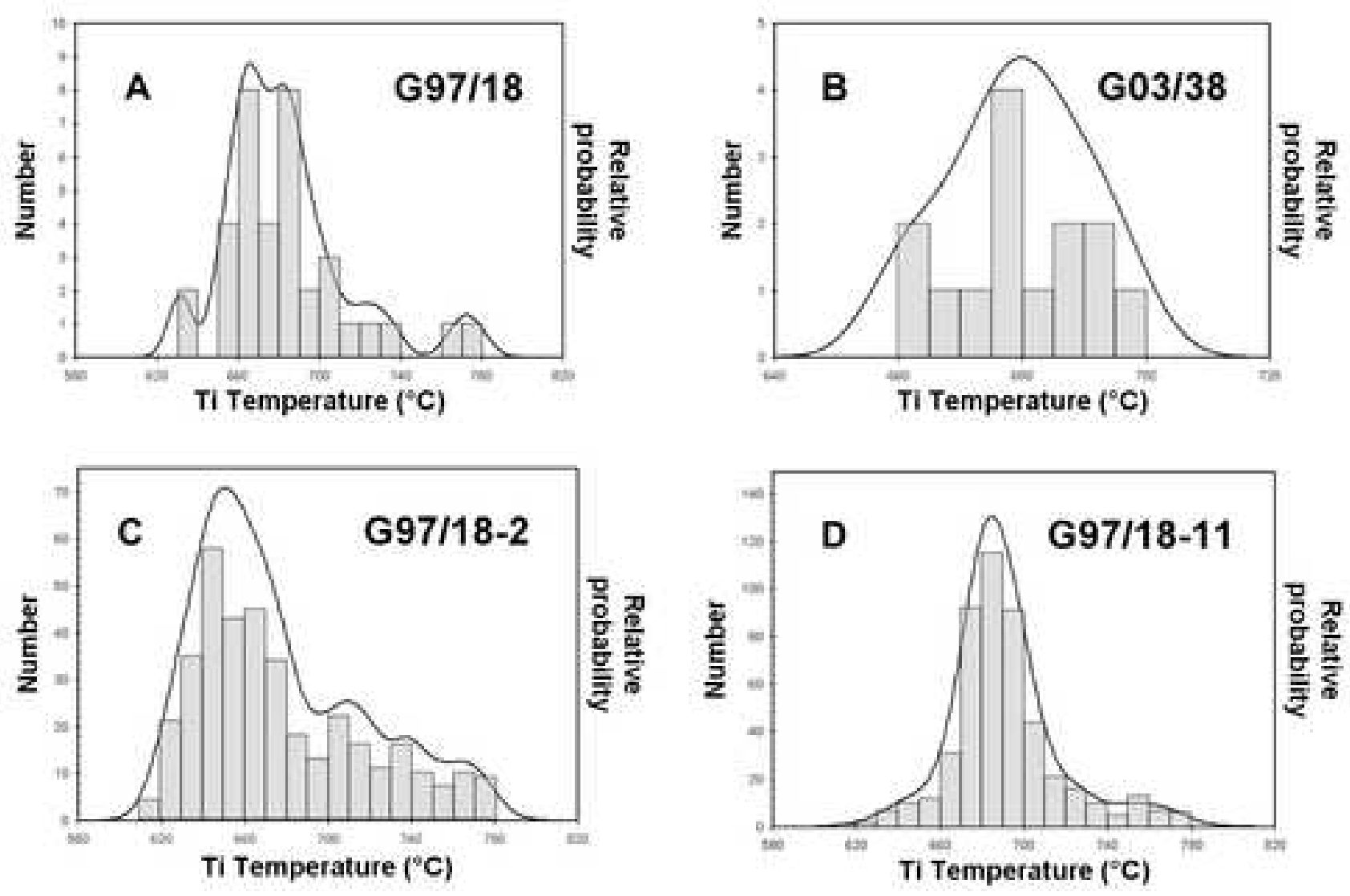
Click here to download high resolution image

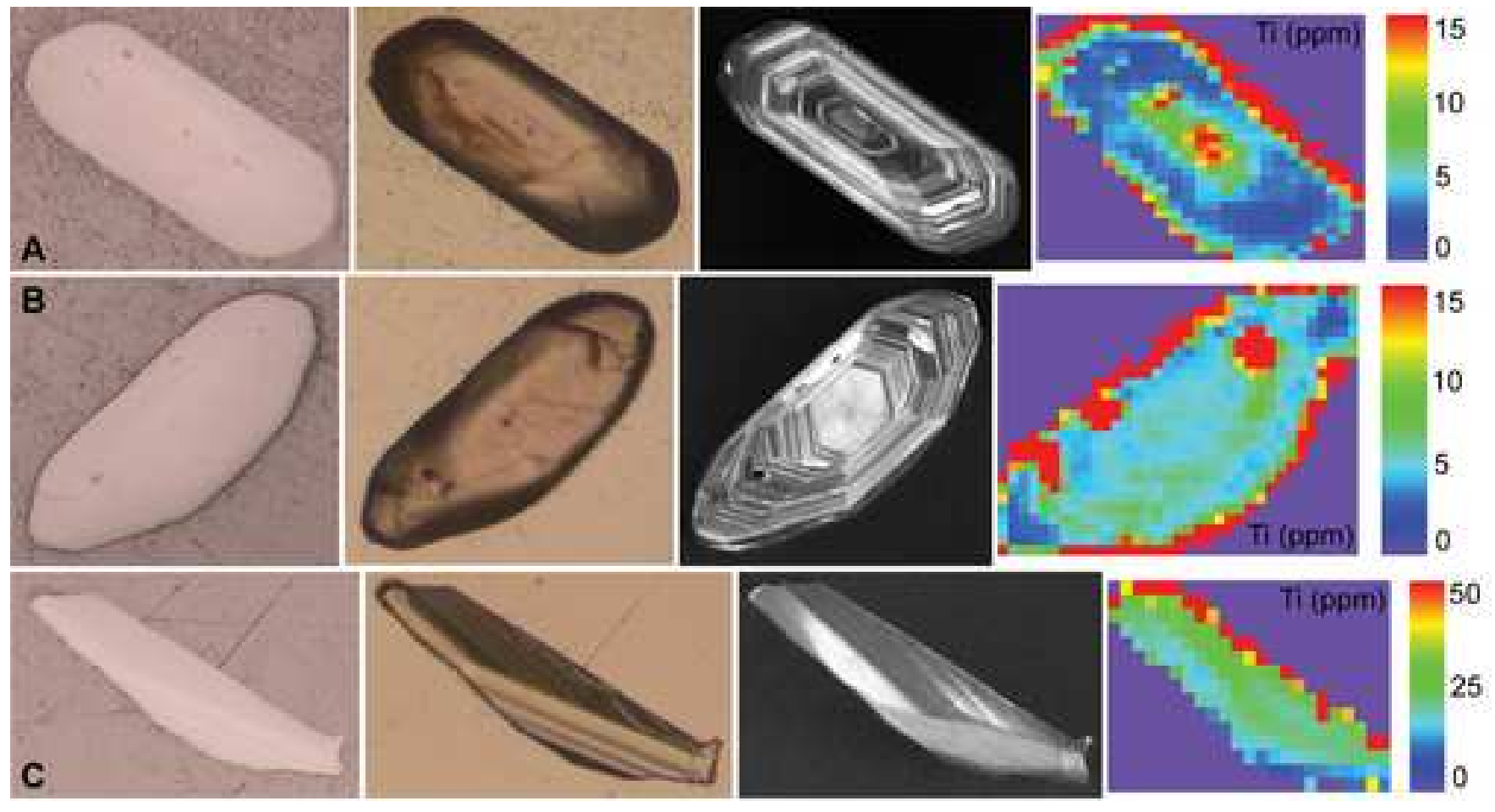


Click here to download high resolution image
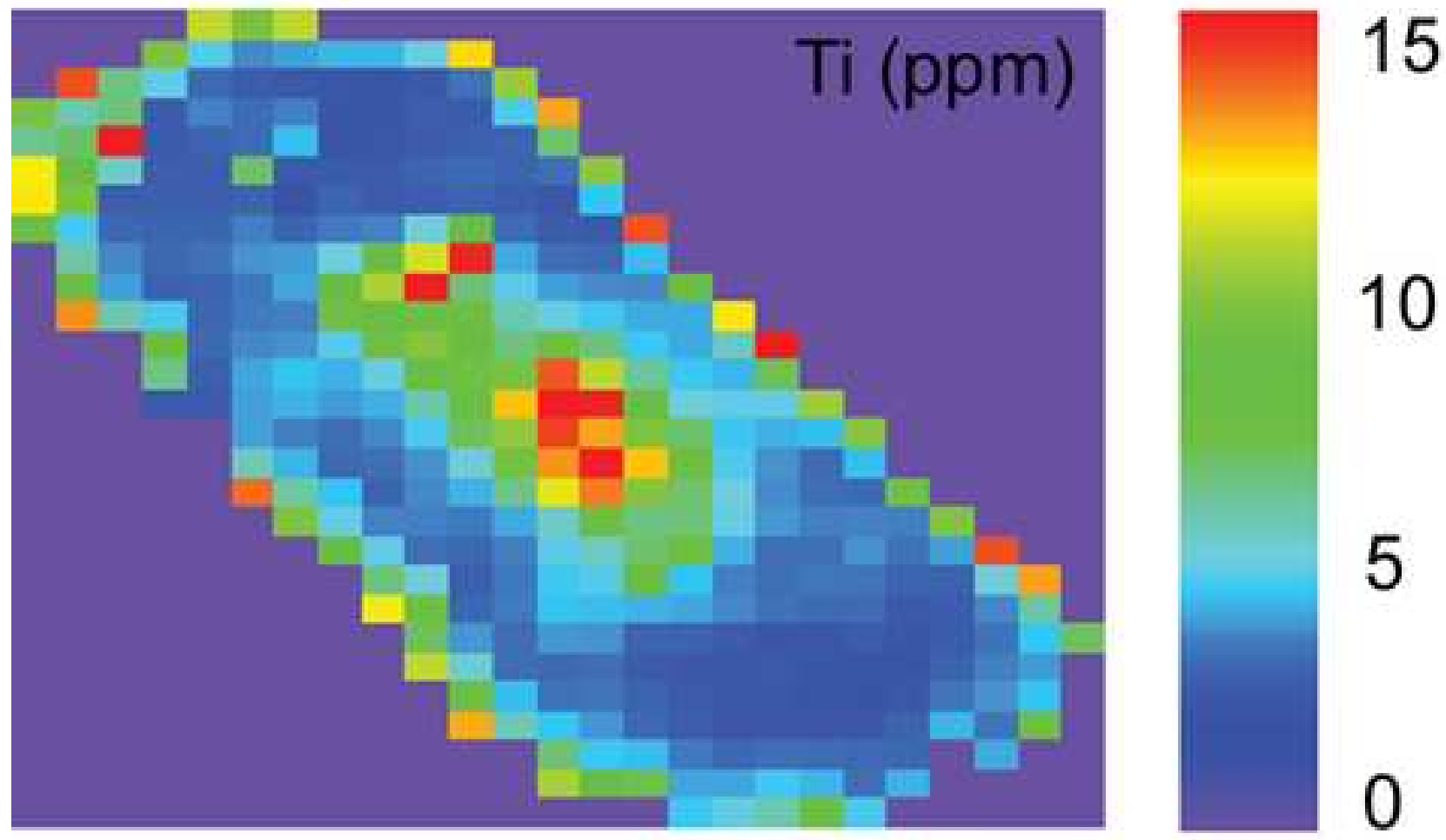
Click here to download high resolution image
Clice 9
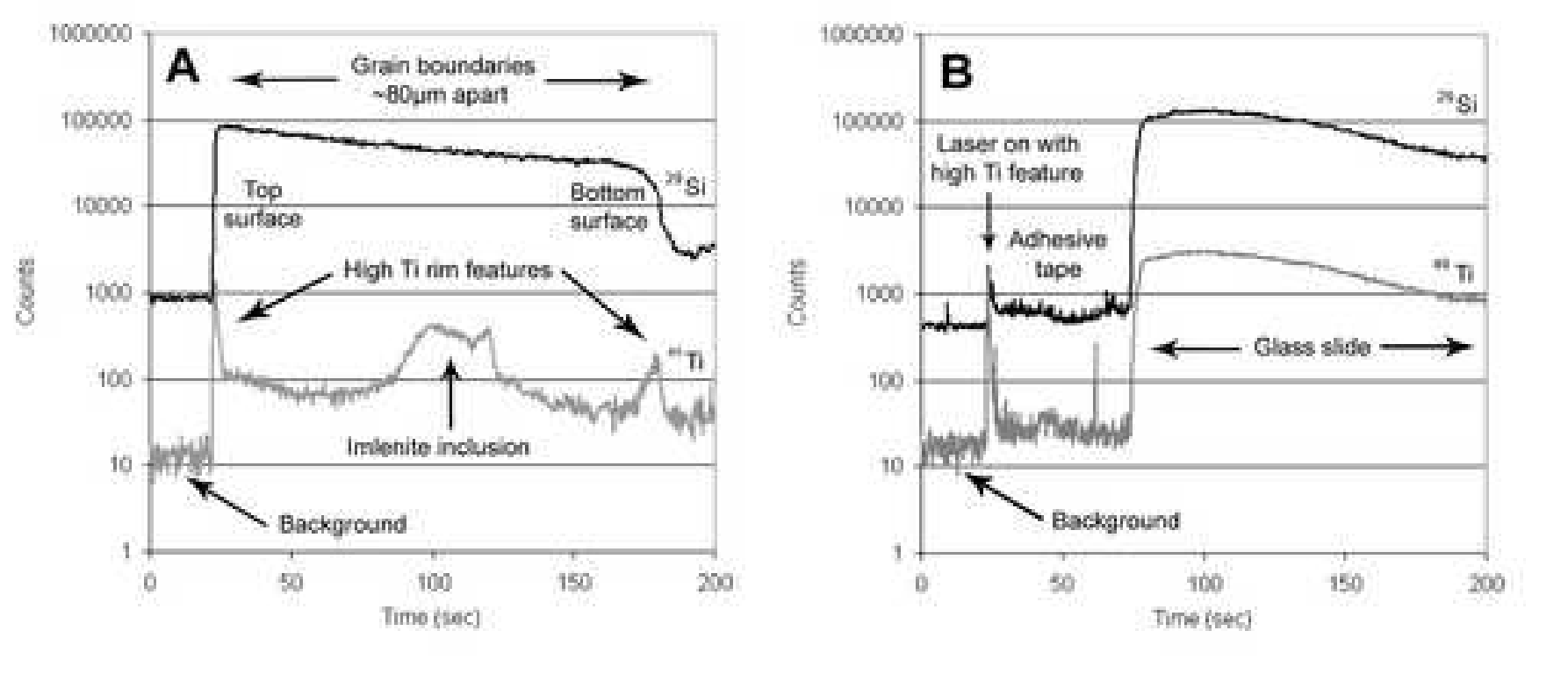

Figure 9

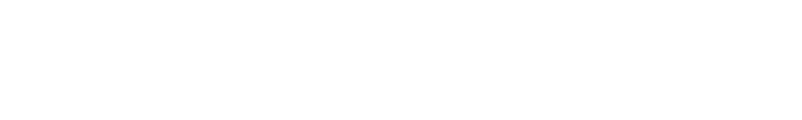

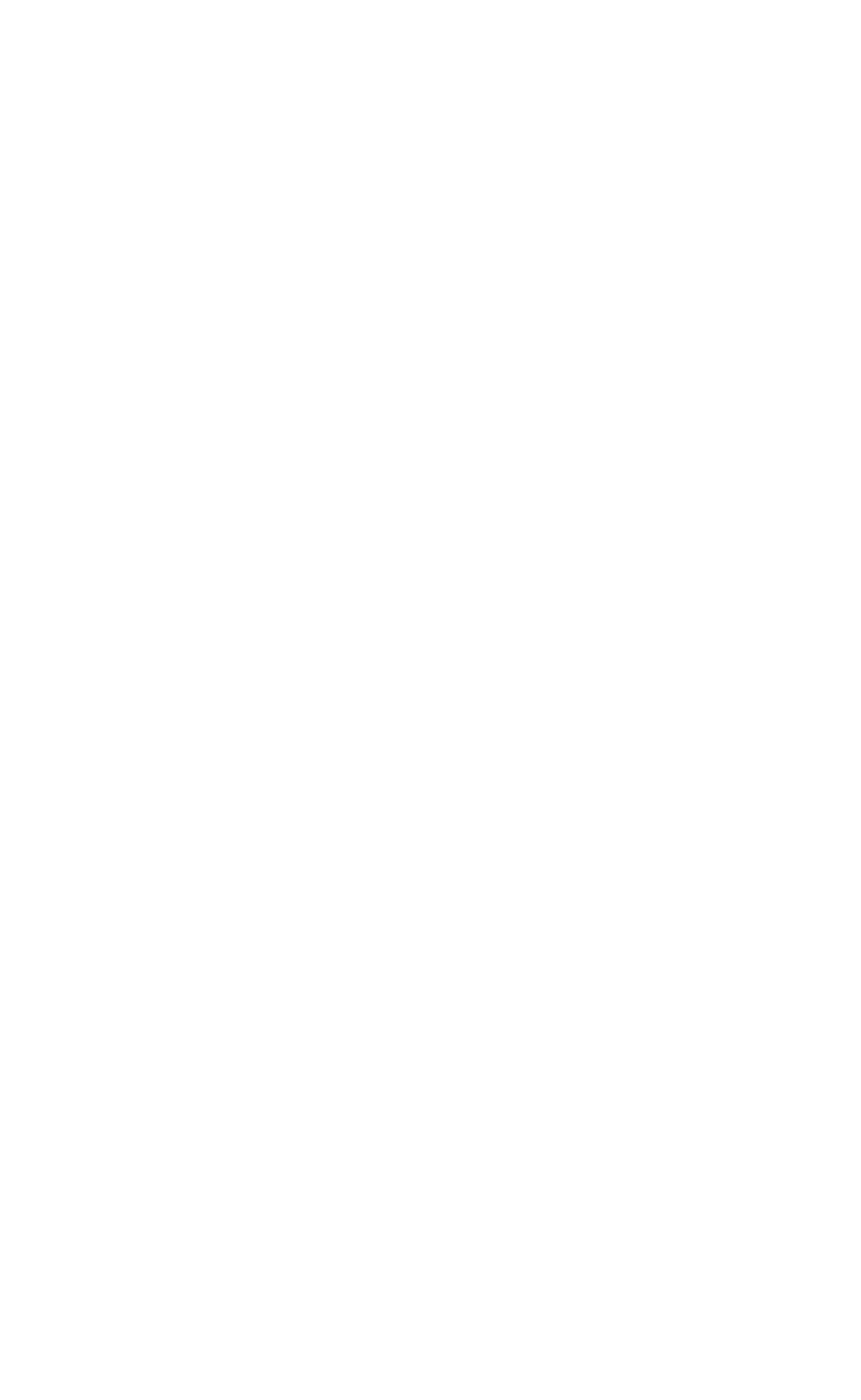

The kect

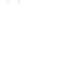




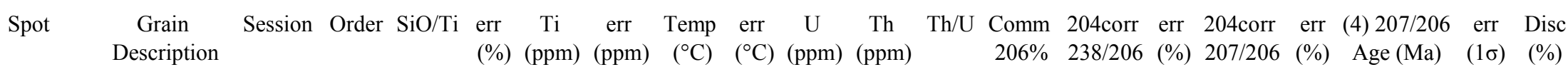

\begin{tabular}{|c|c|c|c|c|c|c|c|c|c|c|c|c|c|c|c|c|c|c|c|c|}
\hline G97-18R-1.1 & $\mathrm{p}, \mathrm{m}, \mathrm{os}, \mathrm{mt}$ & 2 & 11 & 8873 & 0.6 & 4.8 & 0.3 & 681 & 12 & & & & & & & & & & & \\
\hline G97-18R-2.1 & $\mathrm{p}, \mathrm{m}, \mathrm{os}, \mathrm{mt}$ & 2 & 12 & 11196 & 1.1 & 3.8 & 0.2 & 663 & 12 & & & & & & & & & & & \\
\hline G97-18R-3.1 & $\mathrm{p}, \mathrm{m}, \mathrm{os}, \mathrm{mt}$ & 2 & 13 & 11051 & 0.4 & 3.9 & 0.2 & 664 & 12 & & & & & & & & & & & \\
\hline G97-18R-4.1 & $\mathrm{p}, \mathrm{m}, \mathrm{os}, \mathrm{mt}$ & 2 & 15 & 9522 & 0.4 & 4.5 & 0.2 & 675 & 12 & & & & & & & & & & & \\
\hline G97-18R-4.2 & $\mathrm{p}, \mathrm{c}, \mathrm{os}, \mathrm{mt}$ & 2 & 16 & 5638 & 1.2 & 7.6 & 0.4 & 717 & 14 & & & & & & & & & & & \\
\hline G97-18R-5.1 & $\mathrm{p}, \mathrm{m}, \mathrm{os}, \mathrm{mt}$ & 2 & 17 & 6854 & 0.8 & 6.3 & 0.3 & 701 & 13 & & & & & & & & & & & \\
\hline G97-18R-5.2 & $\mathrm{p}, \mathrm{m}, \mathrm{os}, \mathrm{mt}$ & 2 & 18 & 7535 & 0.7 & 5.7 & 0.3 & 694 & 13 & & & & & & & & & & & \\
\hline G97-18R-6.1 & $\mathrm{p}, \mathrm{e}, \mathrm{os}, \mathrm{mt}$ & 2 & 21 & 10411 & 0.8 & 4.1 & 0.2 & 669 & 12 & 122 & 64 & 0.54 & 0.09 & 1.20 & 1.8 & 0.38 & 0.46 & 3820 & 7 & -2 \\
\hline G97-18R-6.2 & $\mathrm{p}, \mathrm{m}, \mathrm{os}, \mathrm{mt}$ & 2 & 22 & 8683 & 0.6 & 4.9 & 0.3 & 682 & 12 & & & & & & & & & & & \\
\hline G97-18R-7.1 & $\mathrm{p}, \mathrm{m}, \mathrm{os}, \mathrm{mt}$ & 2 & 23 & 8640 & 0.6 & 5.0 & 0.3 & 683 & 12 & & & & & & & & & & & \\
\hline G97-18R-8.1 & $\mathrm{p}, \mathrm{m}, \mathrm{os}, \mathrm{mt}$ & 2 & 24 & 6671 & 4.8 & 6.4 & 0.7 & 703 & 22 & & & & & & & & & & & \\
\hline G97-18R-9.1 & $\mathrm{p}, \mathrm{m}, \mathrm{os}, \mathrm{mt}$ & 2 & 26 & 8680 & 0.7 & 4.9 & 0.3 & 682 & 12 & & & & & & & & & & & \\
\hline G97-18R-9.2 & $\mathrm{p}, \mathrm{m}, \mathrm{os}, \mathrm{mt}$ & 2 & 27 & 7999 & 0.7 & 5.4 & 0.3 & 689 & 12 & & & & & & & & & & & \\
\hline G97-18R-10.1 & $\mathrm{p}, \mathrm{m}, \mathrm{os}, \mathrm{mt}$ & 2 & 28 & 13232 & 0.8 & 3.2 & 0.2 & 651 & 12 & 172 & 124 & 0.75 & 0.03 & 1.21 & 1.7 & 0.38 & 0.36 & 3833 & 5 & -1 \\
\hline G97-18R-4.3 & $\mathrm{p}, \mathrm{m}, \mathrm{os}, \mathrm{mt}$ & 2 & 30 & 7316 & 0.9 & 5.9 & 0.3 & 696 & 13 & & & & & & & & & & & \\
\hline G97-18R-3.2 & $\mathrm{p}, \mathrm{e}, \mathrm{os}, \mathrm{d}$ & 2 & 31 & 11697 & 0.7 & 3.7 & 0.2 & 660 & 12 & 148 & 46 & 0.32 & 0.04 & 1.22 & 1.7 & 0.37 & 0.40 & 3809 & 6 & -1 \\
\hline G97-18R-3.3 & $\mathrm{p}, \mathrm{m}, \mathrm{os}, \mathrm{mt}$ & 2 & 32 & 9390 & 0.5 & 4.6 & 0.2 & 676 & 12 & 163 & 58 & 0.37 & 0.05 & 1.22 & 1.7 & 0.37 & 0.50 & 3802 & 8 & -1 \\
\hline G97-18R-3.4 & $\mathrm{p}, \mathrm{c}, \mathrm{rx}, \mathrm{mt}$ & 2 & 33 & 10635 & 0.8 & 4.0 & 0.2 & 667 & 12 & & & & & & & & & & & \\
\hline G97-18R-2.2 & $\mathrm{p}, \mathrm{c}, \mathrm{os}, \mathrm{d}$ & 2 & 35 & 2875 & 0.6 & 14.9 & 0.8 & 777 & 14 & 518 & 501 & 1.00 & 0.01 & 1.22 & 1.5 & 0.37 & 0.26 & 3811 & 4 & -1 \\
\hline G97-18R-2.3 & $\mathrm{p}, \mathrm{m}, \mathrm{os}, \mathrm{d}$ & 2 & 36 & 4571 & 1.1 & 9.4 & 0.5 & 735 & 14 & & & & & & & & & & & \\
\hline G97-18R-2.4 & $\mathrm{p}, \mathrm{e}, \mathrm{os}, \mathrm{mt}$ & 2 & 37 & 17368 & 1.1 & 2.5 & 0.1 & 631 & 12 & 128 & 75 & 0.61 & 0.09 & 1.76 & 1.8 & 0.38 & 0.84 & 3825 & 13 & 32 \\
\hline G97-18R-7.2 & $\mathrm{p}, \mathrm{e}, \mathrm{os}, \mathrm{mt}$ & 2 & 39 & 10892 & 0.8 & 3.9 & 0.2 & 665 & 12 & 167 & 54 & 0.34 & 0.05 & 1.21 & 1.7 & 0.38 & 0.47 & 3819 & 7 & -2 \\
\hline G97-18R-7.3 & $\mathrm{p}, \mathrm{c}, \mathrm{rx}, \mathrm{mt}$ & 2 & 40 & 8352 & 1.0 & 5.1 & 0.3 & 686 & 13 & 55 & 19 & 0.35 & 0.08 & 1.29 & 2.0 & 0.36 & 0.65 & 3741 & 10 & 1 \\
\hline G97-18R-6.3 & $\mathrm{p}, \mathrm{c}, \mathrm{os}, \mathrm{mt}$ & 2 & 41 & 5111 & 0.4 & 8.4 & 0.4 & 726 & 13 & 179 & 78 & 0.45 & 0.04 & 1.26 & 1.6 & 0.37 & 0.45 & 3788 & 7 & 1 \\
\hline G97-18-11.1 & $\mathrm{p}, \mathrm{e}, \mathrm{os}, \mathrm{mt}$ & 3 & 28 & 13704 & 1.0 & 3.5 & 0.2 & 656 & 12 & 204 & 135 & 0.68 & 0.08 & 1.24 & 1.7 & 0.36 & 2.04 & 3763 & 31 & -1 \\
\hline G97-18-11.2 & $\mathrm{p}, \mathrm{m}, \mathrm{os}, \mathrm{mt}$ & 3 & 29 & 3528 & 0.5 & 13.6 & 0.7 & 768 & 14 & & & & & & & & & & & \\
\hline G97-18-11.3 & $\mathrm{p}, \mathrm{m}, \mathrm{os}, \mathrm{mt}$ & 3 & 30 & 12542 & 1.3 & 3.8 & 0.2 & 663 & 13 & & & & & & & & & & & \\
\hline G97-18-11.4 & $\mathrm{p}, \mathrm{c}, \mathrm{rx}, \mathrm{l}$ & 3 & 31 & 10799 & 1.1 & 4.4 & 0.3 & 674 & 13 & 68 & 22 & 0.34 & -0.09 & 1.28 & 2.0 & 0.36 & 0.61 & 3749 & 9 & 1 \\
\hline G97-18-11.5 & $\mathrm{p}, \mathrm{m}, \mathrm{os}, \mathrm{mt}$ & 3 & 32 & 13291 & 0.7 & 3.6 & 0.2 & 658 & 12 & & & & & & & & & & & \\
\hline G97-18-11.6 & $\mathrm{p}, \mathrm{e}, \mathrm{os}, \mathrm{mt}$ & 3 & 33 & 9032 & 1.1 & 5.3 & 0.3 & 688 & 13 & 136 & 100 & 0.76 & 0.26 & 1.26 & 1.7 & 0.37 & 0.42 & 3805 & 6 & 1 \\
\hline G97/18.12.1 & $\mathrm{p}, \mathrm{m}, \mathrm{os}, \mathrm{mt}$ & 3 & 36 & 7301 & 0.9 & 6.6 & 0.4 & 705 & 13 & & & & & & & & & & & \\
\hline G97/18.13.1 & $\mathrm{p}, \mathrm{c}, \mathrm{rx}, \mathrm{mt}$ & 3 & 37 & 19291 & 1.0 & 2.5 & 0.2 & 632 & 12 & & & & & & & & & & & \\
\hline G97/18.13.2 & $\mathrm{p}, \mathrm{m}, \mathrm{os}, \mathrm{mt}$ & 3 & 38 & 14503 & 1.2 & 3.3 & 0.2 & 652 & 12 & & & & & & & & & & & \\
\hline
\end{tabular}




\begin{tabular}{|c|c|c|c|c|c|c|c|c|c|c|c|c|c|c|c|c|c|c|c|c|}
\hline G97/18-14.1 & $\mathrm{p}, \mathrm{m}, \mathrm{os}, \mathrm{mt}$ & 3 & 40 & 10910 & 0.9 & 4.4 & 0.2 & 673 & 12 & & & & & & & & & & & \\
\hline G97/18-14.2 & $\mathrm{p}, \mathrm{m}, \mathrm{os}, \mathrm{mt}$ & 3 & 41 & 11910 & 1.0 & 4.0 & 0.2 & 667 & 12 & & & & & & & & & & & \\
\hline G97/18-15.1 & $\mathrm{p}, \mathrm{m}, \mathrm{os}, \mathrm{mt}$ & 3 & 42 & 9046 & 0.6 & 5.3 & 0.3 & 688 & 12 & & & & & & & & & & & \\
\hline G97-18R-3.5 & $\mathrm{p}, \mathrm{m}, \mathrm{os}, \mathrm{mt}$ & & & & & & & & & 137 & 81 & 0.61 & 0.04 & 1.21 & 1.7 & 0.38 & 0.40 & 3832 & 6 & -1 \\
\hline G97-18R-4.4 & $\mathrm{p}, \mathrm{m}, \mathrm{os}, \mathrm{mt}$ & & & & & & & & & 249 & 166 & 0.69 & 0.04 & 1.19 & 1.6 & 0.38 & 0.45 & 3830 & 7 & -2 \\
\hline G03-38.1 & an, $\mathrm{m}, \mathrm{t}, \mathrm{mt}$ & 3 & 6 & 8600 & 0.8 & 5.6 & 0.3 & 692 & 13 & 79 & 15 & 0.19 & 0.00 & 1.90 & 1.9 & 0.18 & 0.80 & 2691 & 13 & -1 \\
\hline G03-38.2 & ov, m, os, mt & 3 & 7 & 9465 & 0.7 & 5.1 & 0.3 & 684 & 12 & 57 & 10 & 0.18 & 0.18 & 1.91 & 2.0 & 0.19 & 1.03 & 2716 & 17 & 0 \\
\hline G03-38.3 & ov, m, h, 1 & 3 & 8 & 10924 & 0.7 & 4.4 & 0.2 & 673 & 12 & 24 & 7 & 0.31 & 0.30 & 1.87 & 2.7 & 0.19 & 1.52 & 2736 & 25 & -1 \\
\hline G03-38.4 & ov, m, os, 1 & 3 & 10 & 13006 & 1.0 & 3.7 & 0.2 & 660 & 12 & 38 & 9 & 0.23 & 0.12 & 1.74 & 2.0 & 0.19 & 1.68 & 2705 & 28 & -8 \\
\hline G03-38.5 & $\mathrm{ov}, \mathrm{m}, \mathrm{os}, \mathrm{mt}$ & 3 & 11 & 8456 & 0.5 & 5.7 & 0.3 & 693 & 12 & 94 & 26 & 0.29 & 0.15 & 1.84 & 1.7 & 0.19 & 0.53 & 2711 & 9 & -3 \\
\hline G03-38.6 & ov, e, t, mt & 3 & 12 & 10459 & 0.7 & 4.6 & 0.2 & 677 & 12 & 153 & 49 & 0.33 & 0.09 & 1.93 & 1.7 & 0.19 & 0.59 & 2746 & 10 & 2 \\
\hline G03-38.7 & $\mathrm{ov}, \mathrm{m}, \mathrm{t}, \mathrm{l}$ & 3 & 13 & 9351 & 0.9 & 5.1 & 0.3 & 685 & 13 & 47 & 10 & 0.22 & 0.20 & 1.83 & 1.9 & 0.19 & 0.83 & 2730 & 14 & -3 \\
\hline G03-38.8 & $\mathrm{ov}, \mathrm{m}, \mathrm{t}, \mathrm{mt}$ & 3 & 15 & 10136 & 0.9 & 4.7 & 0.3 & 679 & 13 & 71 & 9 & 0.14 & 0.91 & 1.88 & 1.9 & 0.18 & 2.19 & 2667 & 36 & -3 \\
\hline G03-38.9 & $\mathrm{ov}, \mathrm{m}, \mathrm{t}, \mathrm{mt}$ & 3 & 16 & 11676 & 0.7 & 4.1 & 0.2 & 668 & 12 & & & & & & & & & & & \\
\hline G03-38.10 & eq, m, h, 1 & 3 & 17 & 12639 & 0.7 & 3.8 & 0.2 & 662 & 12 & 36 & 13 & 0.37 & 0.16 & 1.71 & 2.3 & 0.19 & 0.93 & 2756 & 15 & -7 \\
\hline G03-38.11 & an, $\mathrm{f}, \mathrm{h}, \mathrm{d}$ & 3 & 18 & 10653 & 0.7 & 4.5 & 0.2 & 675 & 12 & 119 & 16 & 0.14 & 0.02 & 1.85 & 2.3 & 0.19 & 0.57 & 2713 & 9 & -3 \\
\hline G03-38.12 & $\mathrm{ov}, \mathrm{m}, \mathrm{t}, \mathrm{mt}$ & 3 & 20 & 9415 & 0.7 & 5.1 & 0.3 & 685 & 12 & & & & & & & & & & & \\
\hline G03-38.14 & ov, m, os, mt & 3 & 21 & 10161 & 0.8 & 4.7 & 0.3 & 679 & 12 & & & & & & & & & & & \\
\hline G03-38.15 & $\mathrm{ov}, \mathrm{m}, \mathrm{t}, \mathrm{mt}$ & 3 & 22 & 8029 & 0.7 & 6.0 & 0.3 & 697 & 13 & 72 & 23 & 0.33 & 0.07 & 1.84 & 2.7 & 0.18 & 2.91 & 2666 & 48 & -5 \\
\hline
\end{tabular}




\section{Click here to download Table: Table_2.xls}

$\begin{array}{lcccccccc} & \text { cpx-A } & \text { gnt-A } & \text { cpx-B } & \text { gnt-B } & \text { cpx-C } & \text { gnt-C } & \text { cpx-D } & \text { gnt-D } \\ \mathrm{SiO} 2 & 51.01 & 37.30 & 51.27 & 37.54 & 50.33 & 37.37 & 49.47 & 37.85 \\ \mathrm{TiO} 2 & 0.29 & 0.07 & 0.29 & 0.10 & 0.38 & 0.08 & 0.39 & 0.11 \\ \mathrm{~A} 2 \mathrm{O} 3 & 2.30 & 20.69 & 1.97 & 20.74 & 3.06 & 20.84 & 3.46 & 20.44 \\ \mathrm{FeO} & 10.72 & 28.95 & 12.60 & 29.93 & 13.27 & 29.28 & 13.41 & 27.94 \\ \mathrm{MnO} & 0.16 & 1.01 & 0.24 & 1.34 & 0.26 & 1.03 & 0.25 & 1.04 \\ \mathrm{MgO} & 12.26 & 3.80 & 10.47 & 2.91 & 10.23 & 3.72 & 10.50 & 4.00 \\ \mathrm{CaO} & 22.30 & 8.38 & 22.96 & 8.45 & 21.78 & 8.49 & 21.10 & 8.79 \\ \mathrm{Na} 2 \mathrm{O} & 0.50 & 0.03 & 0.02 & 0.01 & 0.51 & 0.02 & 0.50 & 0.00 \\ \mathrm{~K} 2 \mathrm{O} & 0.01 & 0.00 & 0.02 & 0.02 & 0.03 & 0.03 & 0.01 & 0.01 \\ \mathrm{Cr} 2 \mathrm{O} 3 & 0.03 & 0.06 & 0.07 & 0.08 & 0.04 & 0.02 & 0.07 & 0.00 \\ \text { total } & 99.58 & 100.27 & 99.89 & 101.12 & 99.89 & 100.88 & 99.17 & 100.17\end{array}$


Sample

\author{
Grain Treatment
}

G97-18

G03-38

SL13

FC1

Temora-2

Temora-2

Temora-2

Temora-2

Temora-2

Glass

Epoxy

Tape

Untreated grain
Untreated grain
Untreated grain
Untreated grain
Untreated grain
Air abraded grain
ially HF dissolved grain
Acetone rinced grain
Ethanol rinsed grain

Analyses Ti on Profiles reaching

top rim bottom rim

Ti on

Total rims

Total Ti

Total Ti

26
5
17
21
10
4
6
3
3


Background Dataset 1.

Results from analysis on zircon and glass reference materials with operating conditions for each analytical session. SHRIMP SiO/Ti ratios, TiZer and LABRAT Ti concentrations used in zircon calibration.

\begin{tabular}{|c|c|c|c|c|c|c|c|c|c|c|c|c|}
\hline $\begin{array}{r}\text { Reference } \\
\text { Material }\end{array}$ & $\begin{array}{c}\text { Spot } \\
\text { (SHRIMP) }\end{array}$ & Session & Order & $\mathrm{SiO} / \mathrm{Ti}$ & $\operatorname{err}(\%)$ & $\mathrm{Ti} / \mathrm{SiO}$ & err (abs) & $\begin{array}{c}\text { Ti (ppm) } \\
\text { (TiZer) }\end{array}$ & err (ppm) & $\begin{array}{c}\text { Spot } \\
\text { (LA-ICPMS) }\end{array}$ & $\begin{array}{c}\mathrm{Ti}(\mathrm{ppm}) \\
\text { (LABRAT) }\end{array}$ & err (ppm) \\
\hline SL13 & SL13-1.1 & 1 & 47 & 7391 & 0.3 & 0.0001353 & 0.0000004 & 6.1 & 0.4 & & & \\
\hline SL13 & SL13-1.2 & 1 & 48 & 7334 & 0.6 & 0.0001364 & 0.0000008 & 6.2 & 0.4 & & & \\
\hline SL13 & SL13-2.1 & 1 & 49 & 7892 & 0.5 & 0.0001267 & 0.0000006 & 5.7 & 0.3 & & & \\
\hline SL13 & SL13-2.2 & 1 & 50 & 7523 & 0.5 & 0.0001329 & 0.0000007 & 6.0 & 0.4 & & & \\
\hline SL13 & SL13-3.1 & 1 & 51 & 7186 & 0.4 & 0.0001392 & 0.0000006 & 6.3 & 0.4 & & & \\
\hline SL13 & SL13-3.2 & 1 & 52 & 7053 & 0.4 & 0.0001418 & 0.0000006 & 6.4 & 0.4 & & & \\
\hline SL13 & SL13-4.1 & 1 & 53 & 7592 & 0.4 & 0.0001317 & 0.0000005 & 6.0 & 0.3 & & & \\
\hline SL13 & SL13-4.2 & 1 & 54 & 7391 & 0.3 & 0.0001353 & 0.0000004 & 6.1 & 0.4 & & & \\
\hline SL13 & SL13-5.1 & 1 & 55 & 6654 & 0.5 & 0.0001503 & 0.0000008 & 6.8 & 0.4 & & & \\
\hline SL13 & SL13-5.2 & 1 & 56 & 6892 & 0.3 & 0.0001451 & 0.0000004 & 6.6 & 0.4 & & & \\
\hline SL13 & SL13-6.1 & 1 & 57 & 7653 & 0.5 & 0.0001307 & 0.0000007 & 5.9 & 0.3 & & & \\
\hline SL13 & SL13-6.2 & 1 & 58 & 7466 & 0.5 & 0.0001339 & 0.0000007 & 6.1 & 0.4 & & & \\
\hline SL13 & SL13-1.1 & 2 & 1 & 6919 & 0.6 & 0.0001445 & 0.0000009 & 6.2 & 0.3 & J07-SL13-1.0 & 6.3 & 0.5 \\
\hline SL13 & SL13-1.2 & 2 & 2 & 7071 & 0.7 & 0.0001414 & 0.0000010 & 6.1 & 0.3 & & & \\
\hline SL13 & SL13-1.3 & 2 & 7 & 7013 & 0.4 & 0.0001426 & 0.0000006 & 6.1 & 0.3 & & & \\
\hline SL13 & SL13-2.1 & 2 & 14 & 7043 & 0.6 & 0.0001420 & 0.0000009 & 6.1 & 0.3 & J10-SL13-2.6 & 6.4 & 0.5 \\
\hline SL13 & SL13-2.2 & 2 & 19 & 7080 & 0.7 & 0.0001412 & 0.0000010 & 6.1 & 0.3 & & & \\
\hline SL13 & SL13-2.2 & 2 & 20 & 7021 & 0.4 & 0.0001424 & 0.0000006 & 6.1 & 0.3 & & & \\
\hline SL13 & SL13-1.4 & 2 & 25 & 6999 & 0.6 & 0.0001429 & 0.0000009 & 6.1 & 0.3 & J05-SL13-1.4 & 6.5 & 0.6 \\
\hline SL13 & SL13-1.5 & 2 & 29 & 7079 & 0.6 & 0.0001413 & 0.0000008 & 6.1 & 0.3 & & & \\
\hline SL13 & SL13-1.6 & 2 & 34 & 6996 & 0.6 & 0.0001429 & 0.0000009 & 6.1 & 0.3 & & & \\
\hline SL13 & SL13-1.7 & 2 & 38 & 7032 & 0.5 & 0.0001422 & 0.0000007 & 6.1 & 0.3 & J06-SL13-1.7 & 6.3 & 0.5 \\
\hline SL13 & SL13-1.8 & 2 & 42 & 7067 & 0.6 & 0.0001415 & 0.0000008 & 6.1 & 0.3 & & & \\
\hline
\end{tabular}




\begin{tabular}{|c|c|c|c|c|c|c|c|c|c|c|c|c|}
\hline SL13 & SL13-1.9 & 2 & 46 & 6966 & 0.4 & 0.0001436 & 0.0000006 & 6.2 & 0.3 & & & \\
\hline SL13 & SL13-2.3 & 2 & 51 & 6944 & 0.5 & 0.0001440 & 0.0000007 & 6.2 & 0.3 & & & \\
\hline SL13 & SL13-2.4 & 2 & 56 & 6934 & 0.4 & 0.0001442 & 0.0000006 & 6.2 & 0.3 & J14-SL13-2.4 & 6.4 & 0.5 \\
\hline SL13 & SL13-2.5 & 2 & 61 & 6858 & 0.7 & 0.0001458 & 0.0000010 & 6.3 & 0.3 & J13-SL13-2.5 & 6.5 & 0.5 \\
\hline SL13 & SL13-1.9 & 2 & 66 & 6812 & 0.8 & 0.0001468 & 0.0000012 & 6.3 & 0.3 & J04-SL13-1.9 & 6.4 & 0.6 \\
\hline SL13 & SL13-1.9 & 2 & 67 & 6810 & 0.4 & 0.0001468 & 0.0000006 & 6.3 & 0.3 & & & \\
\hline SL13 & SL13-2.6 & 2 & 72 & 6823 & 0.5 & 0.0001466 & 0.0000007 & 6.3 & 0.3 & & & \\
\hline SL13 & SL13-3.1 & 2 & 80 & 7096 & 0.7 & 0.0001409 & 0.0000010 & 6.0 & 0.3 & & & \\
\hline SL13 & SL13-3.2 & 2 & 81 & 7119 & 0.7 & 0.0001405 & 0.0000010 & 6.0 & 0.3 & & & \\
\hline SL13 & SL13-3.3 & 2 & 86 & 7177 & 0.5 & 0.0001393 & 0.0000007 & 6.0 & 0.3 & & & \\
\hline SL13 & SL13-2.7 & 2 & 90 & 7058 & 0.5 & 0.0001417 & 0.0000007 & 6.1 & 0.3 & & & \\
\hline SL13 & SL13-2.8 & 2 & 95 & 7013 & 0.7 & 0.0001426 & 0.0000010 & 6.1 & 0.3 & J11-SL13-2.8 & 6.4 & 0.5 \\
\hline SL13 & SL13-3.4 & 2 & 99 & 7152 & 0.3 & 0.0001398 & 0.0000004 & 6.0 & 0.3 & & & \\
\hline SL13 & SL13-2.9 & 2 & 100 & 6889 & 0.6 & 0.0001452 & 0.0000009 & 6.2 & 0.3 & & & \\
\hline SL13 & SL13-2.10 & 2 & 105 & 6794 & 0.5 & 0.0001472 & 0.0000007 & 6.3 & 0.3 & & & \\
\hline SL13 & SL13-1.10 & 3 & 1 & 7033 & 0.6 & 0.0001422 & 0.0000009 & 6.1 & 0.3 & J03-SL13-1.1 & 6.4 & 0.6 \\
\hline SL13 & SL13-1.11 & 3 & 2 & 6964 & 0.4 & 0.0001436 & 0.0000006 & 6.2 & 0.3 & & & \\
\hline SL13 & SL13-2.10 & 3 & 6 & 7033 & 0.8 & 0.0001422 & 0.0000011 & 6.1 & 0.3 & J12-SL13-2.0 & 6.4 & 0.5 \\
\hline SL13 & SL13.1 & 4 & 5 & 7824 & 0.6 & 0.0001278 & 0.0000008 & 6.1 & 0.3 & & & \\
\hline SL13 & SL13.2 & 4 & 9 & 7709 & 0.6 & 0.0001297 & 0.0000008 & 6.2 & 0.3 & & & \\
\hline SL13 & SL13.3 & 4 & 14 & 7721 & 0.6 & 0.0001295 & 0.0000008 & 6.2 & 0.3 & & & \\
\hline SL13 & SL13.4 & 4 & 19 & 7637 & 0.9 & 0.0001309 & 0.0000012 & 6.3 & 0.3 & & & \\
\hline SL13 & SL13.5 & 4 & 23 & 8040 & 0.7 & 0.0001244 & 0.0000009 & 6.0 & 0.3 & & & \\
\hline SL13 & SL13.7 & 4 & 24 & 7830 & 1.0 & 0.0001277 & 0.0000013 & 6.1 & 0.3 & & & \\
\hline SL13 & SL13.9 & 4 & 25 & 7835 & 0.8 & 0.0001276 & 0.0000010 & 6.1 & 0.3 & & & \\
\hline SL13 & SL13.9B & 4 & 26 & 8048 & 0.6 & 0.0001243 & 0.0000007 & 5.9 & 0.3 & & & \\
\hline SL13 & SL13.9C & 4 & 27 & 7747 & 0.9 & 0.0001291 & 0.0000012 & 6.2 & 0.3 & & & \\
\hline SL13 & SL13.10 & 4 & 35 & 7940 & 0.8 & 0.0001259 & 0.0000010 & 6.0 & 0.3 & & & \\
\hline SL13 & SL13.11 & 4 & 39 & 7825 & 0.5 & 0.0001278 & 0.0000006 & 6.1 & 0.3 & & & \\
\hline SL13 & SL13.12 & 4 & 43 & 7636 & 0.6 & 0.0001310 & 0.0000008 & 6.3 & 0.3 & & & \\
\hline
\end{tabular}




\begin{tabular}{|c|c|c|c|c|c|c|c|c|c|c|c|c|}
\hline SL13 & SL13-3.1 & 5 & 275 & 6873 & 1.6 & 0.0001455 & 0.0000023 & 6.0 & 0.4 & & & \\
\hline SL13 & SL13-3.2 & 5 & 276 & 6795 & 1.2 & 0.0001472 & 0.0000018 & 6.1 & 0.4 & & & \\
\hline SL13 & SL13-3.3 & 5 & 277 & 7011 & 1.0 & 0.0001426 & 0.0000014 & 5.9 & 0.4 & & & \\
\hline SL13 & SL13-3.4 & 5 & 437 & 6702 & 1.6 & 0.0001492 & 0.0000024 & 6.2 & 0.4 & & & \\
\hline SL13 & SL13-3.5 & 5 & 469 & 6453 & 2.3 & 0.0001550 & 0.0000036 & 6.4 & 0.5 & & & \\
\hline SL13 & SL13-3.6 & 5 & 1073 & 7200 & 1.2 & 0.0001389 & 0.0000017 & 5.8 & 0.4 & & & \\
\hline SL13 & SL13-3.7 & 5 & 1074 & 6796 & 1.3 & 0.0001471 & 0.0000019 & 6.1 & 0.4 & & & \\
\hline SL13 & SL13-3.8 & 5 & 1075 & 6470 & 1.3 & 0.0001546 & 0.0000020 & 6.4 & 0.4 & & & \\
\hline SL13 & SL13-3.9 & 5 & 1076 & 7098 & 0.8 & 0.0001409 & 0.0000011 & 5.9 & 0.4 & & & \\
\hline SL13 & SL13-3.10 & 5 & 1077 & 6890 & 0.4 & 0.0001451 & 0.0000006 & 6.0 & 0.4 & & & \\
\hline SL13 & SL13-2.1 & 5 & 1515 & 6005 & 2.1 & 0.0001665 & 0.0000035 & 6.9 & 0.5 & & & \\
\hline Temora-2 & TEM-1.1 & 1 & 31 & 6797 & 0.4 & 0.0001471 & 0.0000006 & 6.6 & 0.4 & & & \\
\hline Temora-2 & TEM-1.2 & 1 & 32 & 6550 & 0.5 & 0.0001527 & 0.0000008 & 6.9 & 0.4 & & & \\
\hline Temora-2 & TEM-1.3 & 1 & 33 & 6453 & 0.5 & 0.0001550 & 0.0000008 & 7.0 & 0.4 & & & \\
\hline Temora-2 & TEM-2.1 & 1 & 34 & 6221 & 0.3 & 0.0001607 & 0.0000005 & 7.3 & 0.4 & & & \\
\hline Temora-2 & TEM-2.2 & 1 & 35 & 6592 & 0.4 & 0.0001517 & 0.0000006 & 6.9 & 0.4 & & & \\
\hline Temora-2 & TEM-2.3 & 1 & 36 & 6589 & 0.4 & 0.0001518 & 0.0000006 & 6.9 & 0.4 & & & \\
\hline Temora-2 & TEM-2.4 & 1 & 37 & 5803 & 0.4 & 0.0001723 & 0.0000007 & 7.8 & 0.4 & & & \\
\hline Temora-2 & TEM-3.1 & 1 & 39 & 5029 & 0.4 & 0.0001988 & 0.0000008 & 9.0 & 0.5 & & & \\
\hline Temora-2 & TEM-3.2 & 1 & 40 & 3906 & 0.8 & 0.0002560 & 0.0000020 & 11.6 & 0.7 & & & \\
\hline Temora-2 & TEM-4.1 & 1 & 41 & 4763 & 0.2 & 0.0002100 & 0.0000004 & 9.5 & 0.5 & & & \\
\hline Temora-2 & TEM-2.1 & 2 & 4 & 4923 & 0.7 & 0.0002031 & 0.0000014 & 8.7 & 0.5 & J17-TEM-2.1 & 8.9 & 0.7 \\
\hline Temora-2 & TEM-1.2 & 2 & 5 & 4552 & 0.3 & 0.0002197 & 0.0000007 & 9.4 & 0.5 & J18-TEM-1.2 & 9.3 & 0.8 \\
\hline Temora-2 & TEM-3.1 & 2 & 6 & 5478 & 0.3 & 0.0001825 & 0.0000005 & 7.8 & 0.4 & J21-TEM-3.2 & 8.4 & 0.7 \\
\hline Temora-2 & TEM-4.1 & 2 & 77 & 4610 & 0.6 & 0.0002169 & 0.0000013 & 9.3 & 0.5 & J22-TEM-4.1 & 9.2 & 0.8 \\
\hline Temora-2 & TEM-5.1 & 2 & 78 & 4438 & 0.5 & 0.0002253 & 0.0000011 & 9.7 & 0.5 & J23-TEM-5.1 & 10.2 & 0.9 \\
\hline Temora-2 & TEM-6.1 & 2 & 79 & 5414 & 0.3 & 0.0001847 & 0.0000006 & 7.9 & 0.4 & J24-TEM-6.1 & 8.2 & 0.7 \\
\hline $\mathrm{FC} 1$ & FC1-1.1 & 1 & 22 & 3524 & 0.2 & 0.0002838 & 0.0000006 & 12.8 & 0.7 & & & \\
\hline
\end{tabular}




\begin{tabular}{|c|c|c|c|c|c|c|c|c|c|c|c|c|}
\hline $\mathrm{FC} 1$ & FC1-2.1 & 1 & 24 & 3841 & 0.3 & 0.0002603 & 0.0000008 & 11.8 & 0.7 & & & \\
\hline $\mathrm{FC} 1$ & FC1-2.2 & 1 & 25 & 3828 & 0.2 & 0.0002612 & 0.0000005 & 11.8 & 0.7 & & & \\
\hline $\mathrm{FC} 1$ & FC1-2.3 & 1 & 26 & 4124 & 0.5 & 0.0002425 & 0.0000012 & 11.0 & 0.6 & & & \\
\hline $\mathrm{FC} 1$ & FC1-3.1 & 1 & 28 & 4021 & 0.3 & 0.0002487 & 0.0000007 & 11.2 & 0.6 & & & \\
\hline $\mathrm{FC} 1$ & FC1-3.2 & 1 & 29 & 3608 & 0.3 & 0.0002772 & 0.0000008 & 12.5 & 0.7 & & & \\
\hline $\mathrm{FC} 1$ & FC1-1.1 & 2 & 8 & 1942 & 0.4 & 0.0005149 & 0.0000021 & 22.1 & 1.1 & J28-FC1-1.1 & 24.0 & 1.9 \\
\hline $\mathrm{FC} 1$ & $\mathrm{FC} 1-1.2$ & 2 & 9 & 2044 & 0.3 & 0.0004892 & 0.0000015 & 21.0 & 1.1 & $\mathrm{~J} 27-\mathrm{FC} 1-1.2$ & 22.3 & 1.9 \\
\hline $\mathrm{FC} 1$ & $\mathrm{FC} 1-2.1$ & 2 & 10 & 1763 & 0.4 & 0.0005672 & 0.0000023 & 24.3 & 1.2 & J30-FC1-2.1 & 25.3 & 2.0 \\
\hline $\mathrm{FC} 1$ & FC1-3.1 & 2 & 73 & 1823 & 0.4 & 0.0005485 & 0.0000022 & 23.5 & 1.2 & J29-FC1-3.1 & 21.4 & 1.8 \\
\hline $\mathrm{FC} 1$ & FC1-4.1 & 2 & 74 & 2266 & 0.2 & 0.0004413 & 0.0000009 & 18.9 & 1.0 & J31-FC1-4.1 & 18.5 & 1.5 \\
\hline $\mathrm{FC} 1$ & FC1-5.1 & 2 & 75 & 1822 & 0.3 & 0.0005488 & 0.0000016 & 23.5 & 1.2 & J32-FC1-5.1 & 20.4 & 1.7 \\
\hline $\mathrm{FC} 1$ & FC1-6.1 & 2 & 76 & 2156 & 0.3 & 0.0004638 & 0.0000014 & 19.9 & 1.0 & J33-FC1-6.1 & 22.0 & 1.8 \\
\hline NIST 610 & NIST 610-1.1 & 1 & 13 & 2663 & 0.0 & 0.0003755 & 0.0000000 & & & & & \\
\hline NIST 610 & NIST 610-2.1 & 1 & 14 & 2601 & 0.1 & 0.0003845 & 0.0000004 & & & & & \\
\hline NIST 610 & NIST $610-2.2$ & 1 & 15 & 2535 & 0.1 & 0.0003945 & 0.0000004 & & & & & \\
\hline NIST 610 & NIST 610-3.1 & 1 & 16 & 2471 & 0.1 & 0.0004047 & 0.0000004 & & & & & \\
\hline NIST 610 & NIST 610-3.2 & 1 & 17 & 2408 & 0.1 & 0.0004153 & 0.0000004 & & & & & \\
\hline NIST 610 & NIST 610-3.3 & 1 & 18 & 2344 & 0.1 & 0.0004266 & 0.0000004 & & & & & \\
\hline NIST 610 & NIST 610-3.3 & 1 & 19 & 2275 & 0.1 & 0.0004396 & 0.0000004 & & & & & \\
\hline NIST 610 & NIST 610-3.3 & 1 & 20 & 2206 & 0.1 & 0.0004533 & 0.0000005 & & & & & \\
\hline NIST 610 & NIST 610-3.3 & 1 & 21 & 2138 & 0.2 & 0.0004677 & 0.0000009 & & & & & \\
\hline NIST 610 & NIST 610-3.4 & 1 & 23 & 2025 & 0.1 & 0.0004938 & 0.0000005 & & & & & \\
\hline NIST 612 & NIST 612-1.1 & 1 & 7 & 5313 & 0.2 & 0.0001882 & 0.0000004 & & & & & \\
\hline NIST 612 & NIST 612-1.2 & 1 & 8 & 5251 & 0.2 & 0.0001904 & 0.0000004 & & & & & \\
\hline NIST 612 & NIST 612-1.3 & 1 & 9 & 5216 & 0.3 & 0.0001917 & 0.0000006 & & & & & \\
\hline NIST 612 & NIST 612-2.1 & 1 & 10 & 5122 & 0.2 & 0.0001952 & 0.0000004 & & & & & \\
\hline NIST 612 & NIST 612-2.2 & 1 & 11 & 5053 & 0.2 & 0.0001979 & 0.0000004 & & & & & \\
\hline NIST 612 & NIST 612-2.3 & 1 & 12 & 5010 & 0.3 & 0.0001996 & 0.0000006 & & & & & \\
\hline
\end{tabular}




$\begin{array}{llllllll}\text { NIST 615 } & \text { NIST 615-1.1 } & 1 & 1 & 39611 & 1.0 & 0.0000252 & 0.0000003 \\ \text { NIST 615 } & \text { NIST 615-1.2 } & 1 & 2 & 39192 & 0.7 & 0.0000255 & 0.0000002 \\ \text { NIST 615 } & \text { NIST 615-2.1 } & 1 & 3 & 39198 & 0.7 & 0.0000255 & 0.0000002 \\ \text { NIST 615 } & \text { NIST 615-2.2 } & 1 & 4 & 40161 & 1.3 & 0.0000249 & 0.0000003 \\ \text { NIST 615 } & \text { NIST 615-2.3 } & 1 & 5 & 39294 & 0.6 & 0.0000254 & 0.0000002 \\ \text { NIST 615 } & \text { NIST 615-2.4 } & 1 & 6 & 39207 & 0.8 & 0.0000255 & 0.0000002 \\ \text { NIST 615 } & \text { NIST 615-1.3 } & 1 & 44 & 36317 & 0.8 & 0.0000275 & 0.0000002 \\ \text { NIST 615 } & \text { NIST 615-1.3 } & 1 & 45 & 36255 & 0.9 & 0.0000276 & 0.0000002 \\ \text { NIST 615 } & \text { NIST 615-1.4 } & 1 & 46 & 36898 & 0.7 & 0.0000271 & 0.0000002 \\ \text { NIST 615 } & \text { NIST 615-1.5 } & 1 & 59 & 35523 & 1.0 & 0.0000282 & 0.0000003\end{array}$


Background Dataset 2.

SHRIMP SiO/Ti ratios, TiZer Ti concentrations and temperatures from matrix mapping of grains G97/18-2, G97/18-11 and FC1-7 during session 5.

Grain Block Spot Order $\mathrm{SiO} / \mathrm{Ti} \quad \operatorname{err}(\%) \quad \mathrm{Ti}(\mathrm{ppm}) \quad \operatorname{err}(\mathrm{ppm}) \quad \mathrm{Temp}\left({ }^{\circ} \mathrm{C}\right) \quad \operatorname{err}\left({ }^{\circ} \mathrm{C}\right)$

\begin{tabular}{|c|c|c|c|c|c|c|c|c|}
\hline G97-18-2 & A & $1 \_8$ & 1078 & 6071 & 2.5 & 6.8 & 0.5 & 709 \\
\hline G97-18-2 & A & $1 \_9$ & 1079 & 133 & 4.6 & 311.3 & 70.6 & 1171 \\
\hline G97-18-2 & A & $1 \_10$ & 1080 & 961 & 11.8 & 43.2 & 12.5 & 888 \\
\hline G97-18-2 & A & $2 \_5$ & 1081 & 4639 & 13.7 & 9.0 & 2.6 & 731 \\
\hline G97-18-2 & A & $2 \_6$ & 1082 & 9691 & 4.1 & 4.3 & 0.5 & 672 \\
\hline G97-18-2 & A & $2-7$ & 1083 & 11023 & 2.4 & 3.8 & 0.3 & 662 \\
\hline G97-18-2 & A & $2 \_8$ & 1084 & 9627 & 1.7 & 4.3 & 0.3 & 672 \\
\hline G97-18-2 & A & $2-9$ & 1085 & 7012 & 1.7 & 5.9 & 0.4 & 697 \\
\hline G97-18-2 & A & $2 \_10$ & 1086 & 3218 & 2.3 & 12.9 & 1.0 & 764 \\
\hline G97-18-2 & A & $2-11$ & 1087 & 677 & 5.5 & 61.3 & 9.4 & 930 \\
\hline G97-18-2 & A & $2 \_12$ & 1088 & 357 & 1.0 & 116.4 & 7.6 & 1015 \\
\hline G97-18-2 & A & $3 \_4$ & 1089 & 10376 & 6.0 & 4.0 & 0.6 & 666 \\
\hline G97-18-2 & A & $3 \_5$ & 1090 & 12721 & 1.4 & 3.3 & 0.3 & 651 \\
\hline G97-18-2 & A & $3 \_6$ & 1091 & 11301 & 2.2 & 3.7 & 0.3 & 660 \\
\hline G97-18-2 & A & $3-7$ & 1092 & 12048 & 1.5 & 3.5 & 0.3 & 655 \\
\hline G97-18-2 & A & 3 & 1093 & 12877 & 0.6 & 3.2 & 0.3 & 650 \\
\hline G97-18-2 & A & 3 & 1094 & 11655 & 1.1 & 3.6 & 0.3 & 658 \\
\hline G97-18-2 & A & $3 \_10$ & 1095 & 8267 & 0.4 & 5.0 & 0.3 & 684 \\
\hline G97-18-2 & A & 3 & 1096 & 2953 & 1.9 & 14.1 & 1.0 & 772 \\
\hline G97-18-2 & A & $3 \_12$ & 1097 & 872 & 6.8 & 47.6 & 8.4 & 900 \\
\hline G97-18-2 & A & $3 \_13$ & 1098 & 468 & 6.1 & 88.7 & 16.1 & 978 \\
\hline G97-18-2 & A & $4 \_3$ & 1100 & 651 & 9.1 & 63.8 & 15.6 & 935 \\
\hline G97-18-2 & A & $4 \_4$ & 1101 & 2122 & 2.2 & 19.6 & 1.5 & 804 \\
\hline G97-18-2 & A & $4 \_5$ & 1102 & 10177 & 0.9 & 4.1 & 0.3 & 668 \\
\hline G97-18-2 & A & $4 \_6$ & 1103 & 12674 & 1.4 & 3.3 & 0.3 & 652 \\
\hline G97-18-2 & A & 4_7 & 1104 & 14848 & 2.5 & 2.8 & 0.3 & 640 \\
\hline G97-18-2 & A & 4_8 & 1105 & 16061 & 1.7 & 2.6 & 0.2 & 635 \\
\hline G97-18-2 & A & $4-9$ & 1106 & 15875 & 1.7 & 2.6 & 0.2 & 635 \\
\hline G97-18-2 & A & 4_10 & 1107 & 14920 & 1.4 & 2.8 & 0.2 & 640 \\
\hline G97-18-2 & A & $4 \_11$ & 1108 & 10794 & 1.6 & 3.9 & 0.3 & 663 \\
\hline G97-18-2 & A & $4 \_12$ & 1109 & 4320 & 4.5 & 9.6 & 1.1 & 737 \\
\hline G97-18-2 & A & $4 \_13$ & 1110 & 709 & 9.3 & 58.5 & 14.3 & 924 \\
\hline G97-18-2 & A & $4 \_15$ & 1112 & 73 & 15.9 & 571.5 & 681.9 & 1289 \\
\hline G97-18-2 & A & $5 \_3$ & 1113 & 10215 & 7.4 & 4.1 & 0.7 & 668 \\
\hline G97-18-2 & A & $5 \_4$ & 1114 & 13939 & 1.2 & 3.0 & 0.3 & 645 \\
\hline G97-18-2 & A & $5 \_5$ & 1115 & 14499 & 2.6 & 2.9 & 0.3 & 642 \\
\hline G97-18-2 & A & $5-6$ & 1116 & 17806 & 1.3 & 2.3 & 0.2 & 627 \\
\hline G97-18-2 & A & $5 \_7$ & 1117 & 20508 & 2.0 & 2.0 & 0.2 & 618 \\
\hline G97-18-2 & A & $5 \_8$ & 1118 & 19085 & 2.3 & 2.2 & 0.2 & 623 \\
\hline G97-18-2 & A & $5 \_9$ & 1119 & 17103 & 2.4 & 2.4 & 0.3 & 630 \\
\hline
\end{tabular}




\begin{tabular}{|c|c|c|c|c|c|c|c|c|c|}
\hline G97-18-2 & $\mathrm{A}$ & 5_10 & 1120 & 14826 & 1.8 & 2.8 & 0.3 & 640 & 17 \\
\hline G97-18-2 & $\mathrm{A}$ & $5 \_11$ & 1121 & 13033 & 1.2 & 3.2 & 0.3 & 650 & 15 \\
\hline G97-18-2 & $\mathrm{A}$ & 5_12 & 1122 & 12063 & 1.5 & 3.4 & 0.3 & 655 & 15 \\
\hline G97-18-2 & $\mathrm{A}$ & $5 \_13$ & 1123 & 4583 & 4.1 & 9.1 & 0.9 & 732 & 22 \\
\hline G97-18-2 & A & $5 \_14$ & 1124 & 717 & 15.3 & 58.0 & 23.0 & 923 & 112 \\
\hline G97-18-2 & A & $5 \_15$ & 1125 & 1131 & 1.2 & 36.7 & 2.4 & 870 & 20 \\
\hline G97-18-2 & A & $6 \_2$ & 1126 & 9193 & 2.9 & 4.5 & 0.4 & 676 & 17 \\
\hline G97-18-2 & A & $6 \_3$ & 1127 & 13255 & 3.2 & 3.1 & 0.3 & 648 & 19 \\
\hline G97-18-2 & $\mathrm{A}$ & $6 \_4$ & 1128 & 13742 & 2.5 & 3.0 & 0.3 & 646 & 17 \\
\hline G97-18-2 & A & $6 \_5$ & 1129 & 17610 & 0.4 & 2.4 & 0.2 & 628 & 17 \\
\hline G97-18-2 & $\mathrm{A}$ & $6 \_6$ & 1130 & 20500 & 2.2 & 2.0 & 0.2 & 618 & 19 \\
\hline G97-18-2 & A & $6 \_7$ & 1131 & 19362 & 1.6 & 2.1 & 0.2 & 622 & 18 \\
\hline G97-18-2 & A & $6 \_8$ & 1132 & 15806 & 1.1 & 2.6 & 0.2 & 636 & 16 \\
\hline G97-18-2 & A & 6_9 & 1133 & 13377 & 1.8 & 3.1 & 0.3 & 648 & 16 \\
\hline G97-18-2 & A & $6 \_10$ & 1134 & 12672 & 0.6 & 3.3 & 0.3 & 652 & 15 \\
\hline G97-18-2 & A & 6_11 & 1135 & 11315 & 1.1 & 3.7 & 0.3 & 660 & 15 \\
\hline G97-18-2 & A & $6 \_12$ & 1136 & 11973 & 0.4 & 3.5 & 0.3 & 656 & 15 \\
\hline G97-18-2 & A & $6 \_13$ & 1137 & 13805 & 0.9 & 3.0 & 0.2 & 645 & 15 \\
\hline G97-18-2 & $\mathrm{A}$ & $6 \_14$ & 1138 & 9856 & 2.1 & 4.2 & 0.3 & 670 & 16 \\
\hline G97-18-2 & A & $6 \_15$ & 1139 & 4275 & 1.1 & 9.7 & 0.6 & 738 & 15 \\
\hline G97-18-2 & A & $7 \_2$ & 1140 & 5674 & 7.9 & 7.3 & 1.3 & 714 & 35 \\
\hline G97-18-2 & A & $7 \_3$ & 1141 & 10085 & 0.5 & 4.1 & 0.3 & 669 & 14 \\
\hline G97-18-2 & A & $7 \_4$ & 1142 & 13544 & 1.5 & 3.1 & 0.3 & 647 & 16 \\
\hline G97-18-2 & A & $7 \_5$ & 1143 & 17706 & 1.4 & 2.4 & 0.2 & 628 & 17 \\
\hline G97-18-2 & A & 7_6 & 1144 & 19983 & 2.1 & 2.1 & 0.2 & 619 & 19 \\
\hline G97-18-2 & A & 7_7 & 1145 & 18543 & 2.2 & 2.2 & 0.2 & 625 & 18 \\
\hline G97-18-2 & A & 7_8 & 1146 & 18691 & 0.8 & 2.2 & 0.2 & 624 & 17 \\
\hline G97-18-2 & A & 7_9 & 1147 & 13744 & 2.0 & 3.0 & 0.3 & 646 & 16 \\
\hline G97-18-2 & $\mathrm{A}$ & $7 \_10$ & 1148 & 12536 & 0.8 & 3.3 & 0.3 & 652 & 15 \\
\hline G97-18-2 & A & $7 \_11$ & 1149 & 13094 & 1.7 & 3.2 & 0.3 & 649 & 16 \\
\hline G97-18-2 & A & $7 \_12$ & 1150 & 12059 & 1.9 & 3.4 & 0.3 & 655 & 16 \\
\hline G97-18-2 & A & $7 \_13$ & 1151 & 13119 & 0.4 & 3.2 & 0.2 & 649 & 15 \\
\hline G97-18-2 & A & $7 \_14$ & 1152 & 13442 & 1.9 & 3.1 & 0.3 & 647 & 16 \\
\hline G97-18-2 & A & $7 \_15$ & 1153 & 9841 & 1.1 & 4.2 & 0.3 & 670 & 15 \\
\hline G97-18-2 & A & $8 \_2$ & 1154 & 7298 & 2.0 & 5.7 & 0.4 & 694 & 16 \\
\hline G97-18-2 & A & $8 \_3$ & 1155 & 9325 & 1.9 & 4.5 & 0.3 & 675 & 16 \\
\hline G97-18-2 & A & $8 \_4$ & 1156 & 13287 & 1.8 & 3.1 & 0.3 & 648 & 16 \\
\hline G97-18-2 & $\mathrm{A}$ & $8 \_5$ & 1157 & 18190 & 2.1 & 2.3 & 0.2 & 626 & 18 \\
\hline G97-18-2 & A & 8_6 & 1158 & 17757 & 1.5 & 2.3 & 0.2 & 628 & 17 \\
\hline G97-18-2 & A & $8 \_7$ & 1159 & 17219 & 2.5 & 2.4 & 0.3 & 630 & 18 \\
\hline G97-18-2 & A & $8 \_8$ & 1160 & 18738 & 2.3 & 2.2 & 0.2 & 624 & 18 \\
\hline G97-18-2 & A & 8_9 & 1161 & 12943 & 0.9 & 3.2 & 0.3 & 650 & 15 \\
\hline G97-18-2 & A & $8 \_10$ & 1162 & 13304 & 0.9 & 3.1 & 0.3 & 648 & 15 \\
\hline G97-18-2 & A & $8 \_11$ & 1163 & 13095 & 1.5 & 3.2 & 0.3 & 649 & 16 \\
\hline G97-18-2 & A & $8 \_12$ & 1164 & 11162 & 1.3 & 3.7 & 0.3 & 661 & 15 \\
\hline G97-18-2 & A & $8 \_13$ & 1165 & 11523 & 2.2 & 3.6 & 0.3 & 659 & 16 \\
\hline
\end{tabular}




\begin{tabular}{|c|c|c|c|c|c|c|c|c|}
\hline G97-18-2 & $\mathrm{A}$ & $8 \_14$ & 1166 & 11383 & 1.4 & 3.7 & 0.3 & 659 \\
\hline G97-18-2 & $\mathrm{A}$ & $8 \_15$ & 1167 & 10267 & 1.9 & 4.0 & 0.3 & 667 \\
\hline G97-18-2 & $\mathrm{A}$ & $9 \_2$ & 1168 & 8635 & 3.8 & 4.8 & 0.5 & 680 \\
\hline G97-18-2 & $\mathrm{A}$ & $9 \_3$ & 1169 & 10660 & 1.0 & 3.9 & 0.3 & 664 \\
\hline G97-18-2 & A & $9-4$ & 1170 & 13867 & 1.5 & 3.0 & 0.3 & 645 \\
\hline G97-18-2 & $\mathrm{A}$ & $9 \_5$ & 1171 & 18074 & 3.6 & 2.3 & 0.3 & 626 \\
\hline G97-18-2 & A & $9 \_6$ & 1172 & 19067 & 1.2 & 2.2 & 0.2 & 623 \\
\hline G97-18-2 & A & $9 \_7$ & 1173 & 18185 & 2.5 & 2.3 & 0.3 & 626 \\
\hline G97-18-2 & $\mathrm{A}$ & 9 & 1174 & 16341 & 1.5 & 2.5 & 0.2 & 633 \\
\hline G97-18-2 & A & $9-9$ & 1175 & 11613 & 1.1 & 3.6 & 0.3 & 658 \\
\hline G97-18-2 & $\mathrm{A}$ & $9 \_10$ & 1176 & 12073 & 1.2 & 3.4 & 0.3 & 655 \\
\hline G97-18-2 & $\mathrm{A}$ & $9-11$ & 1177 & 10290 & 2.1 & 4.0 & 0.3 & 667 \\
\hline G97-18-2 & $\mathrm{A}$ & $9-12$ & 1178 & 8491 & 1.5 & 4.9 & 0.3 & 682 \\
\hline G97-18-2 & A & $9 \_13$ & 1179 & 8373 & 1.0 & 5.0 & 0.3 & 683 \\
\hline G97-18-2 & $\mathrm{A}$ & $9 \_14$ & 1180 & 9056 & 0.7 & 4.6 & 0.3 & 677 \\
\hline G97-18-2 & A & $9 \_15$ & 1181 & 9449 & 1.4 & 4.4 & 0.3 & 674 \\
\hline G97-18-2 & A & $10 \_2$ & 1182 & 9428 & 5.2 & 4.4 & 0.6 & 674 \\
\hline G97-18-2 & A & $10 \_3$ & 1183 & 10613 & 2.8 & 3.9 & 0.4 & 665 \\
\hline G97-18-2 & $\mathrm{A}$ & $10 \_4$ & 1184 & 12308 & 2.2 & 3.4 & 0.3 & 654 \\
\hline G97-18-2 & A & $10 \_5$ & 1185 & 15606 & 1.8 & 2.7 & 0.3 & 637 \\
\hline G97-18-2 & A & $10 \_6$ & 1186 & 16625 & 1.3 & 2.5 & 0.2 & 632 \\
\hline G97-18-2 & $\mathrm{A}$ & $10 \_7$ & 1187 & 17879 & 0.5 & 2.3 & 0.2 & 627 \\
\hline G97-18-2 & $\mathrm{A}$ & $10 \_8$ & 1188 & 14603 & 1.8 & 2.8 & 0.3 & 641 \\
\hline G97-18-2 & A & 10_9 & 1189 & 10685 & 0.8 & 3.9 & 0.3 & 664 \\
\hline G97-18-2 & A & 10_10 & 1190 & 9772 & 2.2 & 4.3 & 0.3 & 671 \\
\hline G97-18-2 & A & 10_11 & 1191 & 5664 & 1.6 & 7.3 & 0.5 & 714 \\
\hline G97-18-2 & A & $10 \_12$ & 1192 & 6405 & 2.2 & 6.5 & 0.5 & 704 \\
\hline G97-18-2 & A & $10 \_13$ & 1193 & 6230 & 0.4 & 6.7 & 0.4 & 707 \\
\hline G97-18-2 & $\mathrm{A}$ & $10 \_14$ & 1194 & 5687 & 0.8 & 7.3 & 0.4 & 714 \\
\hline G97-18-2 & $\mathrm{A}$ & $10 \_15$ & 1195 & 6248 & 0.8 & 6.7 & 0.4 & 706 \\
\hline G97-18-2 & $\mathrm{A}$ & $11 \_2$ & 1196 & 2549 & 5.2 & 16.3 & 2.1 & 786 \\
\hline G97-18-2 & A & $11 \_3$ & 1197 & 5930 & 1.7 & 7.0 & 0.5 & 711 \\
\hline G97-18-2 & $\mathrm{A}$ & $11 \_4$ & 1198 & 10039 & 1.0 & 4.1 & 0.3 & 669 \\
\hline G97-18-2 & A & $11 \_5$ & 1199 & 13724 & 1.4 & 3.0 & 0.3 & 646 \\
\hline G97-18-2 & A & $11 \_6$ & 1200 & 14607 & 0.5 & 2.8 & 0.2 & 641 \\
\hline G97-18-2 & A & $11 \_7$ & 1201 & 16706 & 2.0 & 2.5 & 0.2 & 632 \\
\hline G97-18-2 & A & $11 \_8$ & 1202 & 14640 & 2.7 & 2.8 & 0.3 & 641 \\
\hline G97-18-2 & $\mathrm{A}$ & 11_9 & 1203 & 10299 & 1.1 & 4.0 & 0.3 & 667 \\
\hline G97-18-2 & $\mathrm{A}$ & $11 \_10$ & 1204 & 5173 & 4.6 & 8.0 & 0.9 & 722 \\
\hline G97-18-2 & A & $11 \_11$ & 1205 & 6247 & 2.1 & 6.7 & 0.5 & 706 \\
\hline G97-18-2 & $\mathrm{A}$ & $11 \_12$ & 1206 & 6490 & 1.2 & 6.4 & 0.4 & 703 \\
\hline G97-18-2 & $\mathrm{A}$ & $11 \_13$ & 1207 & 4277 & 1.1 & 9.7 & 0.6 & 738 \\
\hline G97-18-2 & A & $11 \_14$ & 1208 & 3313 & 0.3 & 12.5 & 0.7 & 761 \\
\hline G97-18-2 & $\mathrm{A}$ & $11 \_15$ & 1209 & 4349 & 0.7 & 9.6 & 0.6 & 737 \\
\hline G97-18-2 & A & $12 \_3$ & 1210 & 5200 & 1.1 & 8.0 & 0.5 & 722 \\
\hline G97-18-2 & A & $12 \_4$ & 1211 & 9468 & 1.0 & 4.4 & 0.3 & 673 \\
\hline
\end{tabular}




\begin{tabular}{|c|c|c|c|c|c|c|c|c|}
\hline G97-18-2 & A & 125 & 1212 & 11148 & 1.7 & 3.7 & 0.3 & 661 \\
\hline G97-18-2 & $\mathrm{A}$ & $12 \_6$ & 1213 & 12806 & 1.5 & 3.2 & 0.3 & 651 \\
\hline G97-18-2 & $\mathrm{A}$ & $12-7$ & 1214 & 13120 & 1.4 & 3.2 & 0.3 & 649 \\
\hline G97-18-2 & $\mathrm{A}$ & $12 \_8$ & 1215 & 11356 & 1.1 & 3.7 & 0.3 & 660 \\
\hline G97-18-2 & A & $12 \_9$ & 1216 & 9966 & 0.4 & 4.2 & 0.3 & 669 \\
\hline G97-18-2 & A & $12 \_10$ & 1217 & 8957 & 1.0 & 4.6 & 0.3 & 678 \\
\hline G97-18-2 & A & $12 \_11$ & 1218 & 7680 & 0.9 & 5.4 & 0.3 & 690 \\
\hline G97-18-2 & A & $12 \_12$ & 1219 & 5741 & 1.9 & 7.2 & 0.5 & 713 \\
\hline G97-18-2 & $\mathrm{A}$ & $12 \_13$ & 1220 & 3094 & 0.7 & 13.4 & 0.8 & 768 \\
\hline G97-18-2 & A & $12 \_14$ & 1221 & 2795 & 3.1 & 14.9 & 1.3 & 777 \\
\hline G97-18-2 & $\mathrm{A}$ & $12 \_15$ & 1222 & 3227 & 1.6 & 12.9 & 0.9 & 764 \\
\hline G97-18-2 & $\mathrm{A}$ & 13 & 1223 & 3987 & 2.4 & 10.4 & 0.8 & 745 \\
\hline G97-18-2 & $\mathrm{A}$ & $13{ }^{-} 4$ & 1224 & 6356 & 1.7 & 6.5 & 0.5 & 705 \\
\hline G97-18-2 & A & $13 \_5$ & 1225 & 9552 & 0.6 & 4.4 & 0.3 & 673 \\
\hline G97-18-2 & $\mathrm{A}$ & $13 \_6$ & 1226 & 12941 & 1.1 & 3.2 & 0.3 & 650 \\
\hline G97-18-2 & A & $13 \_7$ & 1227 & 13773 & 1.8 & 3.0 & 0.3 & 646 \\
\hline G97-18-2 & $\mathrm{A}$ & $13 \_8$ & 1228 & 11127 & 1.2 & 3.7 & 0.3 & 661 \\
\hline G97-18-2 & A & 13_9 & 1229 & 9767 & 1.7 & 4.3 & 0.3 & 671 \\
\hline G97-18-2 & $\mathrm{A}$ & $13 \_10$ & 1230 & 9347 & 0.5 & 4.4 & 0.3 & 674 \\
\hline G97-18-2 & A & $13 \_11$ & 1231 & 8865 & 0.9 & 4.7 & 0.3 & 678 \\
\hline G97-18-2 & $\mathrm{A}$ & $13 \_12$ & 1232 & 7743 & 0.7 & 5.4 & 0.3 & 689 \\
\hline G97-18-2 & $\mathrm{A}$ & $13-13$ & 1233 & 3631 & 0.5 & 11.4 & 0.7 & 753 \\
\hline G97-18-2 & $\mathrm{A}$ & $13 \_14$ & 1234 & 3164 & 0.8 & 13.1 & 0.8 & 765 \\
\hline G97-18-2 & A & $13_{-}^{-} 15$ & 1235 & 2919 & 0.6 & 14.2 & 0.9 & 773 \\
\hline G97-18-2 & A & $14 \_4$ & 1236 & 2646 & 8.3 & 15.7 & 3.0 & 782 \\
\hline G97-18-2 & $\mathrm{A}$ & $14 \_5$ & 1237 & 7438 & 1.0 & 5.6 & 0.4 & 692 \\
\hline G97-18-2 & A & $14 \_6$ & 1238 & 9918 & 1.4 & 4.2 & 0.3 & 670 \\
\hline G97-18-2 & A & $14 \_7$ & 1239 & 13240 & 1.5 & 3.1 & 0.3 & 648 \\
\hline G97-18-2 & $\mathrm{A}$ & $14 \_8$ & 1240 & 13383 & 2.1 & 3.1 & 0.3 & 648 \\
\hline G97-18-2 & $\mathrm{A}$ & 14_9 & 1241 & 12266 & 1.6 & 3.4 & 0.3 & 654 \\
\hline G97-18-2 & $\mathrm{A}$ & 14_10 & 1242 & 12563 & 1.0 & 3.3 & 0.3 & 652 \\
\hline G97-18-2 & A & $14 \_11$ & 1243 & 12091 & 1.4 & 3.4 & 0.3 & 655 \\
\hline G97-18-2 & $\mathrm{A}$ & $14 \_12$ & 1244 & 10448 & 2.0 & 4.0 & 0.3 & 666 \\
\hline G97-18-2 & A & 14_13 & 1245 & 6692 & 1.5 & 6.2 & 0.4 & 701 \\
\hline G97-18-2 & $\mathrm{A}$ & 14_14 & 1246 & 4456 & 0.2 & 9.3 & 0.6 & 735 \\
\hline G97-18-2 & A & $14 \_15$ & 1247 & 4139 & 0.4 & 10.0 & 0.6 & 741 \\
\hline G97-18-2 & A & $15 \_5$ & 1248 & 3246 & 1.0 & 12.8 & 0.8 & 763 \\
\hline G97-18-2 & $\mathrm{A}$ & 15 & 1249 & 5506 & 1.5 & 7.5 & 0.5 & 717 \\
\hline G97-18-2 & $\mathrm{A}$ & 15 & 1250 & 8027 & 2.3 & 5.2 & 0.4 & 686 \\
\hline G97-18-2 & A & 15 & 1251 & 11088 & 1.7 & 3.7 & 0.3 & 661 \\
\hline G97-18-2 & $\mathrm{A}$ & 15 & 1252 & 14093 & 0.9 & 3.0 & 0.2 & 644 \\
\hline G97-18-2 & $\mathrm{A}$ & $15 \_10$ & 1253 & 15145 & 0.4 & 2.7 & 0.2 & 639 \\
\hline G97-18-2 & A & $15 \_11$ & 1254 & 14124 & 0.7 & 2.9 & 0.2 & 644 \\
\hline G97-18-2 & $\mathrm{A}$ & 15_12 & 1255 & 12307 & 1.2 & 3.4 & 0.3 & 654 \\
\hline G97-18-2 & A & $15 \_13$ & 1256 & 10317 & 1.1 & 4.0 & 0.3 & 667 \\
\hline G97-18-2 & A & $15 \_14$ & 1257 & 8191 & 0.9 & 5.1 & 0.3 & 685 \\
\hline
\end{tabular}




\begin{tabular}{|c|c|c|c|c|c|c|c|c|}
\hline G97-18-2 & A & 1515 & 1258 & 6025 & 0.6 & 6.9 & 0.4 & 709 \\
\hline G97-18-2 & A & $1 \overline{6} \_7$ & 1259 & 3819 & 3.3 & 10.9 & 1.0 & 748 \\
\hline G97-18-2 & A & $16 \_8$ & 1260 & 6100 & 2.0 & 6.8 & 0.5 & 708 \\
\hline G97-18-2 & A & $16 \_9$ & 1261 & 5676 & 3.5 & 7.3 & 0.7 & 714 \\
\hline G97-18-2 & A & $16 \_10$ & 1262 & 8196 & 2.7 & 5.1 & 0.4 & 685 \\
\hline G97-18-2 & A & $16 \_11$ & 1263 & 13233 & 0.6 & 3.1 & 0.3 & 648 \\
\hline G97-18-2 & A & $16 \_12$ & 1264 & 11991 & 2.3 & 3.5 & 0.3 & 656 \\
\hline G97-18-2 & A & $16 \_13$ & 1265 & 11749 & 0.8 & 3.5 & 0.3 & 657 \\
\hline G97-18-2 & A & $16 \_14$ & 1266 & 11246 & 1.0 & 3.7 & 0.3 & 660 \\
\hline G97-18-2 & A & $16 \_15$ & 1267 & 9249 & 0.7 & 4.5 & 0.3 & 675 \\
\hline G97-18-2 & A & 178 & 1268 & 986 & 4.3 & 42.1 & 5.3 & 885 \\
\hline G97-18-2 & A & $17^{-}$ & 1269 & 3568 & 3.0 & 11.6 & 1.0 & 754 \\
\hline G97-18-2 & $\mathrm{A}$ & 17_-10 & 1270 & 6481 & 2.8 & 6.4 & 0.5 & 703 \\
\hline G97-18-2 & A & 17_11 & 1271 & 8722 & 1.4 & 4.8 & 0.3 & 680 \\
\hline G97-18-2 & A & 17_12 & 1272 & 11913 & 0.6 & 3.5 & 0.3 & 656 \\
\hline G97-18-2 & A & 17_13 & 1273 & 14350 & 1.2 & 2.9 & 0.2 & 643 \\
\hline G97-18-2 & A & 17_14 & 1274 & 13110 & 0.8 & 3.2 & 0.3 & 649 \\
\hline G97-18-2 & A & $17 \_15$ & 1275 & 11617 & 0.6 & 3.6 & 0.3 & 658 \\
\hline G97-18-2 & A & $18 \_10$ & 1276 & 2439 & 3.0 & 17.0 & 1.5 & 790 \\
\hline G97-18-2 & A & 18_11 & 1277 & 5350 & 0.9 & 7.8 & 0.5 & 719 \\
\hline G97-18-2 & A & $18 \_12$ & 1278 & 8589 & 0.7 & 4.8 & 0.3 & 681 \\
\hline G97-18-2 & A & $18 \_13$ & 1279 & 9755 & 2.2 & 4.3 & 0.3 & 671 \\
\hline G97-18-2 & A & $18 \_14$ & 1280 & 13655 & 1.3 & 3.0 & 0.3 & 646 \\
\hline G97-18-2 & A & $18 \_15$ & 1281 & 13236 & 1.1 & 3.1 & 0.3 & 648 \\
\hline G97-18-2 & A & $19 \_12$ & 1282 & 4352 & 0.6 & 9.5 & 0.6 & 737 \\
\hline G97-18-2 & A & $19 \_13$ & 1283 & 7176 & 2.0 & 5.8 & 0.4 & 695 \\
\hline G97-18-2 & A & $19 \_14$ & 1284 & 10178 & 1.1 & 4.1 & 0.3 & 668 \\
\hline G97-18-2 & A & $19 \_15$ & 1285 & 12059 & 1.5 & 3.4 & 0.3 & 655 \\
\hline G97-18-2 & A & $20 \_13$ & 1286 & 3050 & 5.2 & 13.6 & 1.7 & 769 \\
\hline G97-18-2 & A & $20 \_14$ & 1287 & 7514 & 1.3 & 5.5 & 0.4 & 691 \\
\hline G97-18-2 & A & $20 \_15$ & 1288 & 10698 & 1.3 & 3.9 & 0.3 & 664 \\
\hline G97-18-2 & B & $1 \_1$ & 1289 & 1505 & 3.8 & 27.6 & 3.0 & 839 \\
\hline G97-18-2 & B & $1 \_2$ & 1290 & 628 & 2.2 & 66.1 & 5.7 & 940 \\
\hline G97-18-2 & B & $1 \_3$ & 1291 & 385 & 4.3 & 107.8 & 17.4 & 1004 \\
\hline G97-18-2 & B & $2-1$ & 1292 & 4079 & 0.6 & 10.2 & 0.6 & 743 \\
\hline G97-18-2 & B & $2 \_2$ & 1293 & 2393 & 0.2 & 17.4 & 1.0 & 792 \\
\hline G97-18-2 & B & $2 \_3$ & 1294 & 1180 & 3.2 & 35.2 & 3.5 & 865 \\
\hline G97-18-2 & B & $2 \_4$ & 1295 & 208 & 3.0 & 200.1 & 31.3 & 1097 \\
\hline G97-18-2 & B & 3 & 1296 & 8625 & 1.4 & 4.8 & 0.3 & 681 \\
\hline G97-18-2 & B & 32 & 1297 & 6041 & 1.8 & 6.9 & 0.5 & 709 \\
\hline G97-18-2 & B & $3 \_3$ & 1298 & 2772 & 2.2 & 15.0 & 1.1 & 778 \\
\hline G97-18-2 & B & $3-4$ & 1299 & 1030 & 8.6 & 40.3 & 9.2 & 880 \\
\hline G97-18-2 & B & $3 \_5$ & 1300 & 862 & 1.8 & 48.2 & 3.7 & 901 \\
\hline G97-18-2 & B & $3 \_6$ & 1301 & 672 & 5.1 & 61.8 & 9.7 & 931 \\
\hline G97-18-2 & B & 4_1 & 1302 & 8752 & 1.4 & 4.7 & 0.3 & 679 \\
\hline G97-18-2 & B & $4 \_2$ & 1303 & 10189 & 1.7 & 4.1 & 0.3 & 668 \\
\hline
\end{tabular}




\begin{tabular}{|c|c|c|c|c|c|c|c|c|c|}
\hline G97-18-2 & $\mathrm{B}$ & 4_3 & 1304 & 7529 & 1.5 & 5.5 & 0.4 & 691 & 15 \\
\hline G97-18-2 & $\mathrm{B}$ & 44 & 1305 & 3451 & 1.0 & 12.0 & 0.8 & 757 & 16 \\
\hline G97-18-2 & $\mathrm{B}$ & $4 \_5$ & 1306 & 2204 & 0.7 & 18.8 & 1.1 & 800 & 17 \\
\hline G97-18-2 & $\mathrm{B}$ & $4-6$ & 1307 & 1250 & 1.4 & 33.2 & 2.3 & 859 & 20 \\
\hline G97-18-2 & $\mathrm{B}$ & $4 \_7$ & 1308 & 312 & 13.6 & 133.2 & 70.6 & 1034 & 179 \\
\hline G97-18-2 & B & $5 \_1$ & 1309 & 8209 & 1.3 & 5.1 & 0.3 & 684 & 15 \\
\hline G97-18-2 & B & $5 \_2$ & 1310 & 9496 & 1.8 & 4.4 & 0.3 & 673 & 15 \\
\hline G97-18-2 & $\mathrm{B}$ & $5 \_3$ & 1311 & 10409 & 1.7 & 4.0 & 0.3 & 666 & 15 \\
\hline G97-18-2 & $\mathrm{B}$ & $5 \_4$ & 1312 & 10458 & 1.7 & 4.0 & 0.3 & 666 & 15 \\
\hline G97-18-2 & $\mathrm{B}$ & $5 \_5$ & 1313 & 5388 & 0.9 & 7.7 & 0.5 & 719 & 15 \\
\hline G97-18-2 & $\mathrm{B}$ & $5 \_6$ & 1314 & 2126 & 2.0 & 19.5 & 1.4 & 803 & 19 \\
\hline G97-18-2 & $\mathrm{B}$ & $5-7$ & 1315 & 203 & 4.2 & 204.1 & 44.1 & 1100 & 81 \\
\hline G97-18-2 & $\mathrm{B}$ & 599 & 1317 & 144 & 2.7 & 288.4 & 51.0 & 1158 & 73 \\
\hline G97-18-2 & $\mathrm{B}$ & $6 \_1$ & 1318 & 5168 & 1.1 & 8.0 & 0.5 & 722 & 15 \\
\hline G97-18-2 & B & $6 \_2$ & 1319 & 6848 & 0.7 & 6.1 & 0.4 & 699 & 14 \\
\hline G97-18-2 & B & $6 \_3$ & 1320 & 9432 & 0.6 & 4.4 & 0.3 & 674 & 14 \\
\hline G97-18-2 & $\mathrm{B}$ & $6 \_4$ & 1321 & 10395 & 1.3 & 4.0 & 0.3 & 666 & 15 \\
\hline G97-18-2 & $\mathrm{B}$ & $6 \_5$ & 1322 & 11718 & 1.4 & 3.5 & 0.3 & 657 & 15 \\
\hline G97-18-2 & $\mathrm{B}$ & $6 \_6$ & 1323 & 9929 & 1.7 & 4.2 & 0.3 & 670 & 15 \\
\hline G97-18-2 & $\mathrm{B}$ & $6 \_7$ & 1324 & 2966 & 0.9 & 14.0 & 0.9 & 771 & 16 \\
\hline G97-18-2 & $\mathrm{B}$ & $6 \_8$ & 1325 & 2206 & 1.5 & 18.8 & 1.3 & 800 & 18 \\
\hline G97-18-2 & $\mathrm{B}$ & $6 \_9$ & 1326 & 460 & 0.7 & 90.3 & 5.6 & 980 & 23 \\
\hline G97-18-2 & $\mathrm{B}$ & $6 \_10$ & 1327 & 300 & 14.5 & 138.2 & 80.9 & 1040 & 199 \\
\hline G97-18-2 & $\mathrm{B}$ & $\overline{7} 1$ & 1328 & 2810 & 0.7 & 14.8 & 0.9 & 776 & 16 \\
\hline G97-18-2 & $\mathrm{B}$ & $7 \_2$ & 1329 & 3840 & 0.3 & 10.8 & 0.6 & 748 & 15 \\
\hline G97-18-2 & $\mathrm{B}$ & $7 \_3$ & 1330 & 6573 & 1.6 & 6.3 & 0.4 & 702 & 15 \\
\hline G97-18-2 & $\mathrm{B}$ & $7 \_4$ & 1331 & 9344 & 1.7 & 4.4 & 0.3 & 674 & 15 \\
\hline G97-18-2 & $\mathrm{B}$ & $7 \_5$ & 1332 & 11504 & 1.7 & 3.6 & 0.3 & 659 & 16 \\
\hline G97-18-2 & $\mathrm{B}$ & $7 \_6$ & 1333 & 13759 & 0.8 & 3.0 & 0.2 & 646 & 15 \\
\hline G97-18-2 & $\mathrm{B}$ & $7 \_7$ & 1334 & 16529 & 2.0 & 2.5 & 0.3 & 633 & 17 \\
\hline G97-18-2 & $\mathrm{B}$ & $7 \_8$ & 1335 & 9630 & 1.9 & 4.3 & 0.3 & 672 & 15 \\
\hline G97-18-2 & $\mathrm{B}$ & 7_9 & 1336 & 4221 & 1.3 & 9.8 & 0.6 & 740 & 16 \\
\hline G97-18-2 & $\mathrm{B}$ & $7-10$ & 1337 & 2412 & 0.5 & 17.2 & 1.0 & 791 & 16 \\
\hline G97-18-2 & B & $7 \_11$ & 1338 & 1244 & 2.6 & 33.4 & 2.9 & 859 & 24 \\
\hline G97-18-2 & $\mathrm{B}$ & $7 \_12$ & 1339 & 707 & 5.4 & 58.7 & 9.7 & 925 & 48 \\
\hline G97-18-2 & B & $8 \_1$ & 1340 & 2233 & 1.0 & 18.6 & 1.2 & 799 & 17 \\
\hline G97-18-2 & $\mathrm{B}$ & $8 \_2$ & 1341 & 2982 & 0.6 & 13.9 & 0.8 & 771 & 16 \\
\hline G97-18-2 & $\mathrm{B}$ & $8 \_3$ & 1342 & 5734 & 0.9 & 7.2 & 0.4 & 713 & 14 \\
\hline G97-18-2 & $\mathrm{B}$ & $8 \_4$ & 1343 & 8568 & 0.6 & 4.9 & 0.3 & 681 & 14 \\
\hline G97-18-2 & $\mathrm{B}$ & $8 \_5$ & 1344 & 10755 & 1.0 & 3.9 & 0.3 & 664 & 15 \\
\hline G97-18-2 & $\mathrm{B}$ & $8 \_6$ & 1345 & 13215 & 1.2 & 3.1 & 0.3 & 648 & 15 \\
\hline G97-18-2 & $\mathrm{B}$ & $8-7$ & 1346 & 16001 & 2.0 & 2.6 & 0.3 & 635 & 17 \\
\hline G97-18-2 & B & 8_8 & 1347 & 18038 & 1.4 & 2.3 & 0.2 & 626 & 17 \\
\hline G97-18-2 & B & $8 \_9$ & 1348 & 13253 & 2.4 & 3.1 & 0.3 & 648 & 17 \\
\hline G97-18-2 & $\mathrm{B}$ & $8 \_10$ & 1349 & 6302 & 1.2 & 6.6 & 0.4 & 706 & 14 \\
\hline G97-18-2 & B & $8 \_11$ & 1350 & 3233 & 1.7 & 12.8 & 0.9 & 763 & 17 \\
\hline
\end{tabular}




\begin{tabular}{|c|c|c|c|c|c|c|c|c|c|}
\hline G97-18-2 & $\mathrm{B}$ & 8_12 & 1351 & 431 & 34.0 & 96.3 & 113.5 & 989 & 369 \\
\hline G97-18-2 & $\mathrm{B}$ & $9 \_1$ & 1353 & 3321 & 1.4 & 12.5 & 0.8 & 761 & 16 \\
\hline G97-18-2 & $\mathrm{B}$ & 9_2 & 1354 & 4398 & 0.4 & 9.4 & 0.6 & 736 & 15 \\
\hline G97-18-2 & $\mathrm{B}$ & $9 \_3$ & 1355 & 6463 & 0.6 & 6.4 & 0.4 & 704 & 14 \\
\hline G97-18-2 & B & 9_4 & 1356 & 7327 & 1.2 & 5.7 & 0.4 & 693 & 14 \\
\hline G97-18-2 & B & $9 \_5$ & 1357 & 8816 & 0.9 & 4.7 & 0.3 & 679 & 14 \\
\hline G97-18-2 & B & 9_6 & 1358 & 10434 & 1.4 & 4.0 & 0.3 & 666 & 15 \\
\hline G97-18-2 & B & 9_7 & 1359 & 13562 & 0.9 & 3.1 & 0.3 & 647 & 15 \\
\hline G97-18-2 & B & $9 \_8$ & 1360 & 15746 & 2.0 & 2.6 & 0.3 & 636 & 17 \\
\hline G97-18-2 & B & 9 & 1361 & 14518 & 1.9 & 2.9 & 0.3 & 642 & 17 \\
\hline G97-18-2 & $\mathrm{B}$ & $9 \_10$ & 1362 & 14300 & 1.3 & 2.9 & 0.3 & 643 & 16 \\
\hline G97-18-2 & $\mathrm{B}$ & $9-11$ & 1363 & 9087 & 1.7 & 4.6 & 0.3 & 677 & 15 \\
\hline G97-18-2 & $\mathrm{B}$ & $9-12$ & 1364 & 4108 & 3.3 & 10.1 & 0.9 & 742 & 21 \\
\hline G97-18-2 & B & $9 \_13$ & 1365 & 404 & 32.4 & 102.8 & 119.8 & 998 & 371 \\
\hline G97-18-2 & B & $10 \_1$ & 1367 & 5153 & 0.1 & 8.1 & 0.5 & 722 & 14 \\
\hline G97-18-2 & B & $10 \_2$ & 1368 & 4585 & 1.4 & 9.1 & 0.6 & 732 & 16 \\
\hline G97-18-2 & B & $10 \_3$ & 1369 & 5186 & 1.7 & 8.0 & 0.6 & 722 & 16 \\
\hline G97-18-2 & $\mathrm{B}$ & $10 \_4$ & 1370 & 5705 & 1.2 & 7.3 & 0.5 & 714 & 15 \\
\hline G97-18-2 & B & $10 \_5$ & 1371 & 6354 & 1.0 & 6.5 & 0.4 & 705 & 14 \\
\hline G97-18-2 & B & $10 \_6$ & 1372 & 2815 & 0.7 & 14.8 & 0.9 & 776 & 16 \\
\hline G97-18-2 & $\mathrm{B}$ & $10 \_7$ & 1373 & 4969 & 1.7 & 8.4 & 0.6 & 725 & 16 \\
\hline G97-18-2 & $\mathrm{B}$ & $10-8$ & 1374 & 14393 & 2.0 & 2.9 & 0.3 & 642 & 17 \\
\hline G97-18-2 & $\mathrm{B}$ & $10 \_9$ & 1375 & 13647 & 1.3 & 3.0 & 0.3 & 646 & 16 \\
\hline G97-18-2 & B & $10 \_10$ & 1376 & 15192 & 0.4 & 2.7 & 0.2 & 638 & 16 \\
\hline G97-18-2 & B & 10_11 & 1377 & 16569 & 1.4 & 2.5 & 0.2 & 632 & 17 \\
\hline G97-18-2 & $\mathrm{B}$ & $10 \_12$ & 1378 & 13047 & 2.3 & 3.2 & 0.3 & 649 & 17 \\
\hline G97-18-2 & $\mathrm{B}$ & $10 \_13$ & 1379 & 3394 & 6.7 & 12.2 & 1.9 & 759 & 34 \\
\hline G97-18-2 & B & $10 \_14$ & 1380 & 414 & 9.4 & 100.4 & 34.5 & 994 & 109 \\
\hline G97-18-2 & B & $11 \_1$ & 1381 & 7254 & 1.1 & 5.7 & 0.4 & 694 & 14 \\
\hline G97-18-2 & $\mathrm{B}$ & $11 \_2$ & 1382 & 5288 & 1.1 & 7.9 & 0.5 & 720 & 15 \\
\hline G97-18-2 & $\mathrm{B}$ & $11 \_3$ & 1383 & 4262 & 0.5 & 9.7 & 0.6 & 739 & 15 \\
\hline G97-18-2 & $\mathrm{B}$ & $11 \_4$ & 1384 & 5539 & 0.7 & 7.5 & 0.5 & 716 & 14 \\
\hline G97-18-2 & B & $11 \_5$ & 1385 & 2126 & 9.4 & 19.5 & 4.4 & 803 & 52 \\
\hline G97-18-2 & B & $11 \_6$ & 1386 & 3703 & 1.5 & 11.2 & 0.8 & 751 & 16 \\
\hline G97-18-2 & B & $11 \_7$ & 1387 & 8276 & 0.7 & 5.0 & 0.3 & 684 & 14 \\
\hline G97-18-2 & B & $11 \_8$ & 1388 & 15434 & 1.5 & 2.7 & 0.2 & 637 & 16 \\
\hline G97-18-2 & B & $11 \_9$ & 1389 & 14317 & 1.4 & 2.9 & 0.3 & 643 & 16 \\
\hline G97-18-2 & $\mathrm{B}$ & $11 \_10$ & 1390 & 16413 & 2.3 & 2.5 & 0.3 & 633 & 18 \\
\hline G97-18-2 & B & $11 \_11$ & 1391 & 15391 & 1.3 & 2.7 & 0.2 & 638 & 16 \\
\hline G97-18-2 & B & $11 \_12$ & 1392 & 17142 & 2.0 & 2.4 & 0.2 & 630 & 18 \\
\hline G97-18-2 & $\mathrm{B}$ & $11 \_13$ & 1393 & 8423 & 1.8 & 4.9 & 0.4 & 682 & 15 \\
\hline G97-18-2 & $\mathrm{B}$ & $11 \_14$ & 1394 & 1649 & 4.9 & 25.2 & 3.3 & 829 & 33 \\
\hline G97-18-2 & B & $11 \_15$ & 1395 & 158 & 1.1 & 263.3 & 23.3 & 1142 & 38 \\
\hline G97-18-2 & B & $12 \_1$ & 1396 & 10216 & 2.8 & 4.1 & 0.4 & 668 & 17 \\
\hline G97-18-2 & B & $12 \_2$ & 1397 & 8522 & 0.6 & 4.9 & 0.3 & 681 & 14 \\
\hline G97-18-2 & B & $12 \_3$ & 1398 & 5824 & 0.5 & 7.1 & 0.4 & 712 & 14 \\
\hline
\end{tabular}




\begin{tabular}{|c|c|c|c|c|c|c|c|c|c|}
\hline G97-18-2 & B & $12 \_4$ & 1399 & 4783 & 1.6 & 8.7 & 0.6 & 729 & 16 \\
\hline G97-18-2 & B & $12 \_5$ & 1400 & 3946 & 0.7 & 10.5 & 0.6 & 745 & 15 \\
\hline G97-18-2 & B & $12 \_6$ & 1401 & 5168 & 1.5 & 8.0 & 0.5 & 722 & 15 \\
\hline G97-18-2 & B & $12-7$ & 1402 & 11793 & 1.2 & 3.5 & 0.3 & 657 & 15 \\
\hline G97-18-2 & B & $12-8$ & 1403 & 16446 & 2.7 & 2.5 & 0.3 & 633 & 18 \\
\hline G97-18-2 & B & 12_9 & 1404 & 16482 & 0.5 & 2.5 & 0.2 & 633 & 16 \\
\hline G97-18-2 & B & $12 \_10$ & 1405 & 18479 & 1.5 & 2.3 & 0.2 & 625 & 18 \\
\hline G97-18-2 & B & $12 \_11$ & 1406 & 18738 & 2.2 & 2.2 & 0.2 & 624 & 18 \\
\hline G97-18-2 & B & $12 \_12$ & 1407 & 19944 & 2.8 & 2.1 & 0.2 & 620 & 20 \\
\hline G97-18-2 & B & $12 \_13$ & 1408 & 10100 & 3.1 & 4.1 & 0.4 & 668 & 18 \\
\hline G97-18-2 & B & $12 \_14$ & 1409 & 2678 & 1.1 & 15.5 & 1.0 & 781 & 17 \\
\hline G97-18-2 & B & $12 \_15$ & 1410 & 394 & 1.1 & 105.5 & 7.5 & 1001 & 26 \\
\hline G97-18-2 & B & $13_{-}^{-} 1$ & 1411 & 10977 & 0.3 & 3.8 & 0.3 & 662 & 14 \\
\hline G97-18-2 & B & $13 \_2$ & 1412 & 10283 & 1.6 & 4.0 & 0.3 & 667 & 15 \\
\hline G97-18-2 & B & $13 \_3$ & 1413 & 8943 & 0.9 & 4.6 & 0.3 & 678 & 14 \\
\hline G97-18-2 & B & $13 \_4$ & 1414 & 5832 & 0.7 & 7.1 & 0.4 & 712 & 14 \\
\hline G97-18-2 & B & $13 \_5$ & 1415 & 5186 & 1.2 & 8.0 & 0.5 & 722 & 15 \\
\hline G97-18-2 & B & $13 \_6$ & 1416 & 8322 & 1.0 & 5.0 & 0.3 & 683 & 14 \\
\hline G97-18-2 & B & $13 \_7$ & 1417 & 12327 & 1.5 & 3.4 & 0.3 & 654 & 15 \\
\hline G97-18-2 & B & $13 \_8$ & 1418 & 14163 & 4.1 & 2.9 & 0.3 & 643 & 21 \\
\hline G97-18-2 & B & 13_9 & 1419 & 16576 & 1.1 & 2.5 & 0.2 & 632 & 17 \\
\hline G97-18-2 & B & $13 \_10$ & 1420 & 19364 & 2.0 & 2.1 & 0.2 & 622 & 18 \\
\hline G97-18-2 & B & 13_11 & 1421 & 18612 & 1.3 & 2.2 & 0.2 & 624 & 17 \\
\hline G97-18-2 & B & $13 \_12$ & 1422 & 18206 & 0.5 & 2.3 & 0.2 & 626 & 17 \\
\hline G97-18-2 & B & $13 \_13$ & 1423 & 10134 & 5.5 & 4.1 & 0.5 & 668 & 24 \\
\hline G97-18-2 & B & $13 \_14$ & 1424 & 2066 & 2.7 & 20.1 & 1.7 & 806 & 22 \\
\hline G97-18-2 & B & $14 \_1$ & 1426 & 10228 & 2.2 & 4.1 & 0.3 & 667 & 16 \\
\hline G97-18-2 & B & $14 \_2$ & 1427 & 9740 & 0.7 & 4.3 & 0.3 & 671 & 14 \\
\hline G97-18-2 & B & $14 \_3$ & 1428 & 11228 & 0.4 & 3.7 & 0.3 & 660 & 14 \\
\hline G97-18-2 & B & $14 \_4$ & 1429 & 12157 & 1.2 & 3.4 & 0.3 & 655 & 15 \\
\hline G97-18-2 & B & $14 \_5$ & 1430 & 10652 & 3.3 & 3.9 & 0.4 & 664 & 18 \\
\hline G97-18-2 & B & $14 \_6$ & 1431 & 11004 & 0.5 & 3.8 & 0.3 & 662 & 14 \\
\hline G97-18-2 & B & $14 \_7$ & 1432 & 14385 & 2.0 & 2.9 & 0.3 & 642 & 17 \\
\hline G97-18-2 & B & $14 \_8$ & 1433 & 20677 & 2.8 & 2.0 & 0.2 & 617 & 20 \\
\hline G97-18-2 & B & 14_9 & 1434 & 16673 & 1.6 & 2.5 & 0.2 & 632 & 17 \\
\hline G97-18-2 & B & $14 \_10$ & 1435 & 9852 & 4.8 & 4.2 & 0.5 & 670 & 22 \\
\hline G97-18-2 & B & $14 \_11$ & 1436 & 12077 & 1.9 & 3.4 & 0.3 & 655 & 16 \\
\hline G97-18-2 & B & $14 \_12$ & 1437 & 17023 & 2.0 & 2.4 & 0.2 & 630 & 18 \\
\hline G97-18-2 & B & $14 \_13$ & 1438 & 10816 & 2.1 & 3.8 & 0.3 & 663 & 16 \\
\hline G97-18-2 & B & $14 \_14$ & 1439 & 3840 & 2.2 & 10.8 & 0.8 & 748 & 18 \\
\hline G97-18-2 & B & $14 \_15$ & 1440 & 316 & 1.4 & 131.3 & 10.9 & 1032 & 31 \\
\hline G97-18-2 & B & $15 \_1$ & 1441 & 10760 & 2.9 & 3.9 & 0.4 & 664 & 18 \\
\hline G97-18-2 & B & $15 \_2$ & 1442 & 10640 & 2.4 & 3.9 & 0.3 & 665 & 17 \\
\hline G97-18-2 & B & $15 \_3$ & 1443 & 11598 & 1.1 & 3.6 & 0.3 & 658 & 15 \\
\hline G97-18-2 & B & $15 \_4$ & 1444 & 12413 & 0.7 & 3.4 & 0.3 & 653 & 15 \\
\hline G97-18-2 & B & $15 \_5$ & 1445 & 12519 & 1.8 & 3.3 & 0.3 & 652 & 16 \\
\hline
\end{tabular}




\begin{tabular}{|c|c|c|c|c|c|c|c|c|}
\hline G97-18-2 & B & 156 & 1446 & 11377 & 0.8 & 3.7 & 0.3 & 659 \\
\hline G97-18-2 & B & 15 & 1447 & 11993 & 1.4 & 3.5 & 0.3 & 656 \\
\hline G97-18-2 & B & $15 \_8$ & 1448 & 14491 & 0.3 & 2.9 & 0.2 & 642 \\
\hline G97-18-2 & B & $15-9$ & 1449 & 6227 & 18.7 & 6.7 & 2.7 & 707 \\
\hline G97-18-2 & B & $15 \_10$ & 1450 & 13489 & 2.6 & 3.1 & 0.3 & 647 \\
\hline G97-18-2 & B & $15 \_11$ & 1451 & 13395 & 1.8 & 3.1 & 0.3 & 648 \\
\hline G97-18-2 & B & 15_12 & 1452 & 15965 & 1.9 & 2.6 & 0.3 & 635 \\
\hline G97-18-2 & B & $15 \_13$ & 1453 & 11693 & 1.9 & 3.6 & 0.3 & 657 \\
\hline G97-18-2 & B & $15 \_14$ & 1454 & 4447 & 1.5 & 9.3 & 0.6 & 735 \\
\hline G97-18-2 & B & $15-15$ & 1455 & 2073 & 3.8 & 20.0 & 2.1 & 806 \\
\hline G97-18-2 & B & $1 \overline{6} \_1$ & 1456 & 15788 & 1.7 & 2.6 & 0.2 & 636 \\
\hline G97-18-2 & B & $16 \_2$ & 1457 & 15284 & 1.7 & 2.7 & 0.3 & 638 \\
\hline G97-18-2 & B & $16 \_3$ & 1458 & 13730 & 2.2 & 3.0 & 0.3 & 646 \\
\hline G97-18-2 & B & $16 \_4$ & 1459 & 14000 & 1.0 & 3.0 & 0.2 & 644 \\
\hline G97-18-2 & B & $16 \_5$ & 1460 & 14401 & 2.1 & 2.9 & 0.3 & 642 \\
\hline G97-18-2 & B & $16 \_6$ & 1461 & 12917 & 2.3 & 3.2 & 0.3 & 650 \\
\hline G97-18-2 & B & $16 \_7$ & 1462 & 14219 & 1.4 & 2.9 & 0.3 & 643 \\
\hline G97-18-2 & B & $16 \_8$ & 1463 & 15495 & 1.4 & 2.7 & 0.2 & 637 \\
\hline G97-18-2 & B & 16_9 & 1464 & 15623 & 2.2 & 2.7 & 0.3 & 637 \\
\hline G97-18-2 & B & $16 \_10$ & 1465 & 14661 & 3.4 & 2.8 & 0.3 & 641 \\
\hline G97-18-2 & B & $16 \_11$ & 1466 & 11860 & 3.3 & 3.5 & 0.4 & 656 \\
\hline G97-18-2 & B & $16 \_12$ & 1467 & 13845 & 3.1 & 3.0 & 0.3 & 645 \\
\hline G97-18-2 & B & $16 \_13$ & 1468 & 9018 & 2.2 & 4.6 & 0.4 & 677 \\
\hline G97-18-2 & B & $16 \_14$ & 1469 & 3816 & 3.8 & 10.9 & 1.1 & 748 \\
\hline G97-18-2 & B & $16 \_15$ & 1470 & 1260 & 4.0 & 33.0 & 3.9 & 858 \\
\hline G97-18-2 & B & 17 & 1471 & 16574 & 6.2 & 2.5 & 0.4 & 632 \\
\hline G97-18-2 & B & $17 \_2$ & 1472 & 6628 & 3.2 & 6.3 & 0.6 & 701 \\
\hline G97-18-2 & B & $17 \_3$ & 1473 & 5418 & 1.4 & 7.7 & 0.5 & 718 \\
\hline G97-18-2 & B & 174 & 1474 & 9196 & 0.6 & 4.5 & 0.3 & 676 \\
\hline G97-18-2 & B & $17 \_5$ & 1475 & 14759 & 0.6 & 2.8 & 0.2 & 641 \\
\hline G97-18-2 & B & $17-6$ & 1476 & 14000 & 2.9 & 3.0 & 0.3 & 644 \\
\hline G97-18-2 & B & 17 _7 & 1477 & 14216 & 1.0 & 2.9 & 0.2 & 643 \\
\hline G97-18-2 & B & $17 \_8$ & 1478 & 15310 & 0.4 & 2.7 & 0.2 & 638 \\
\hline G97-18-2 & B & 17_9 & 1479 & 15411 & 1.3 & 2.7 & 0.2 & 637 \\
\hline G97-18-2 & B & 17_10 & 1480 & 16796 & 2.0 & 2.5 & 0.2 & 631 \\
\hline G97-18-2 & B & 17_11 & 1481 & 15808 & 2.7 & 2.6 & 0.3 & 636 \\
\hline G97-18-2 & B & $17 \_12$ & 1482 & 8752 & 2.2 & 4.7 & 0.4 & 679 \\
\hline G97-18-2 & B & $17 \_13$ & 1483 & 4375 & 3.5 & 9.5 & 0.9 & 736 \\
\hline G97-18-2 & B & $17 \_14$ & 1484 & 1188 & 2.5 & 34.9 & 3.1 & 864 \\
\hline G97-18-2 & B & $17_{-}^{-} 15$ & 1485 & 112 & 2.0 & 370.3 & 67.8 & 1203 \\
\hline G97-18-2 & B & $18 \_3$ & 1486 & 1930 & 2.0 & 21.5 & 1.6 & 813 \\
\hline G97-18-2 & B & $18 \_4$ & 1487 & 7328 & 1.5 & 5.7 & 0.4 & 693 \\
\hline G97-18-2 & B & $18 \_5$ & 1488 & 10819 & 0.6 & 3.8 & 0.3 & 663 \\
\hline G97-18-2 & B & 18_6 & 1489 & 11717 & 2.3 & 3.5 & 0.3 & 657 \\
\hline G97-18-2 & B & $18 \_7$ & 1490 & 14020 & 0.7 & 3.0 & 0.2 & 644 \\
\hline G97-18-2 & B & $18 \_8$ & 1491 & 15591 & 2.8 & 2.7 & 0.3 & 637 \\
\hline
\end{tabular}




\begin{tabular}{|c|c|c|c|c|c|c|c|c|}
\hline G97-18-2 & B & $18 \_9$ & 1492 & 7785 & 5.5 & 5.3 & 0.7 & 689 \\
\hline G97-18-2 & B & $18-10$ & 1493 & 2681 & 5.8 & 15.5 & 2.3 & 781 \\
\hline G97-18-2 & B & $18 \_11$ & 1494 & 6403 & 1.9 & 6.5 & 0.5 & 704 \\
\hline G97-18-2 & $\mathrm{B}$ & $18-12$ & 1495 & 6538 & 2.8 & 6.4 & 0.5 & 703 \\
\hline G97-18-2 & $\mathrm{B}$ & $18 \_13$ & 1496 & 2214 & 5.2 & 18.8 & 2.6 & 799 \\
\hline G97-18-2 & $\mathrm{B}$ & $18 \_14$ & 1497 & 307 & 3.2 & 135.1 & 21.3 & 1036 \\
\hline G97-18-2 & $\mathrm{B}$ & 194 & 1498 & 3149 & 6.2 & 13.2 & 2.0 & 766 \\
\hline G97-18-2 & $\mathrm{B}$ & 1955 & 1499 & 5429 & 0.9 & 7.7 & 0.5 & 718 \\
\hline G97-18-2 & $\mathrm{B}$ & $19-6$ & 1500 & 7176 & 0.8 & 5.8 & 0.4 & 695 \\
\hline G97-18-2 & $\mathrm{B}$ & 19 & 1501 & 9180 & 2.0 & 4.5 & 0.4 & 676 \\
\hline G97-18-2 & B & $19 \_8$ & 1502 & 4370 & 3.4 & 9.5 & 0.9 & 737 \\
\hline G97-18-2 & B & 19 -9 & 1503 & 4951 & 4.8 & 8.4 & 1.0 & 726 \\
\hline G97-18-2 & B & $19 \_10$ & 1504 & 6215 & 4.4 & 6.7 & 0.7 & 707 \\
\hline G97-18-2 & $\mathrm{B}$ & $19 \_11$ & 1505 & 7310 & 1.9 & 5.7 & 0.4 & 694 \\
\hline G97-18-2 & B & $19 \_12$ & 1506 & 2949 & 2.5 & 14.1 & 1.2 & 772 \\
\hline G97-18-2 & $\mathrm{B}$ & $19 \_13$ & 1507 & 795 & 6.8 & 52.2 & 11.0 & 911 \\
\hline G97-18-2 & $\mathrm{B}$ & $20-6$ & 1508 & 2492 & 4.3 & 16.7 & 1.9 & 788 \\
\hline G97-18-2 & $\mathrm{B}$ & $20-7$ & 1509 & 4684 & 2.1 & 8.9 & 0.7 & 730 \\
\hline G97-18-2 & $\mathrm{B}$ & $20 \_8$ & 1510 & 3448 & 7.5 & 12.0 & 2.1 & 758 \\
\hline G97-18-2 & $\mathrm{B}$ & $20 \_9$ & 1511 & 3461 & 4.2 & 12.0 & 1.3 & 757 \\
\hline G97-18-2 & B & $20 \_10$ & 1512 & 6726 & 1.7 & 6.2 & 0.4 & 700 \\
\hline G97-18-2 & B & $20 \_11$ & 1513 & 4412 & 4.5 & 9.4 & 1.1 & 736 \\
\hline G97-18-2 & $\mathrm{B}$ & $20 \_12$ & 1514 & 1318 & 3.6 & 31.5 & 3.5 & 853 \\
\hline G97-18-11 & A & $1 \_18$ & 470 & 978 & 9.5 & 42.5 & 7.6 & 886 \\
\hline G97-18-11 & A & $1 \_19$ & 471 & 2922 & 1.8 & 14.2 & 1.0 & 773 \\
\hline G97-18-11 & A & 1_20 & 472 & 3394 & 6.1 & 12.2 & 1.6 & 759 \\
\hline G97-18-11 & A & $2 \_15$ & 473 & 1483 & 5.6 & 28.0 & 3.3 & 840 \\
\hline G97-18-11 & $\mathrm{A}$ & $2-16$ & 474 & 1746 & 17.2 & 23.8 & 7.8 & 823 \\
\hline G97-18-11 & A & $2 \_17$ & 475 & 2389 & 6.1 & 17.4 & 2.3 & 792 \\
\hline G97-18-11 & A & $2 \_18$ & 476 & 2362 & 5.1 & 17.6 & 2.0 & 793 \\
\hline G97-18-11 & A & $2 \_19$ & 477 & 4809 & 0.6 & 8.6 & 0.5 & 728 \\
\hline G97-18-11 & $\mathrm{A}$ & $2 \_20$ & 478 & 7688 & 0.7 & 5.4 & 0.3 & 690 \\
\hline G97-18-11 & A & $3 \_13$ & 479 & 769 & 4.0 & 54.0 & 4.9 & 915 \\
\hline G97-18-11 & A & $3 \_14$ & 480 & 1927 & 16.7 & 21.6 & 6.9 & 813 \\
\hline G97-18-11 & A & $3 \_15$ & 481 & 3744 & 1.2 & 11.1 & 0.7 & 750 \\
\hline G97-18-11 & A & $3 \_16$ & 482 & 2552 & 6.8 & 16.3 & 2.3 & 786 \\
\hline G97-18-11 & A & $3 \_17$ & 483 & 5267 & 2.0 & 7.9 & 0.6 & 720 \\
\hline G97-18-11 & $\mathrm{A}$ & $3 \_18$ & 484 & 6050 & 2.0 & 6.9 & 0.5 & 709 \\
\hline G97-18-11 & A & $3 \_19$ & 485 & 8551 & 0.4 & 4.9 & 0.3 & 681 \\
\hline G97-18-11 & A & $3 \_20$ & 486 & 8550 & 1.1 & 4.9 & 0.3 & 681 \\
\hline G97-18-11 & A & $4 \_12$ & 487 & 1485 & 6.1 & 28.0 & 3.6 & 840 \\
\hline G97-18-11 & A & 4_13 & 488 & 2842 & 5.0 & 14.6 & 1.7 & 775 \\
\hline G97-18-11 & A & $4 \_14$ & 489 & 3548 & 4.5 & 11.7 & 1.2 & 755 \\
\hline G97-18-11 & A & $4 \_15$ & 490 & 4537 & 6.8 & 9.2 & 1.3 & 733 \\
\hline G97-18-11 & A & $4-16$ & 491 & 5877 & 3.6 & 7.1 & 0.7 & 711 \\
\hline
\end{tabular}




\begin{tabular}{|c|c|c|c|c|c|c|c|c|c|}
\hline G97-18-11 & A & 4_17 & 492 & 7886 & 0.8 & 5.3 & 0.3 & 688 & 14 \\
\hline G97-18-11 & A & 4_18 & 493 & 8960 & 1.9 & 4.6 & 0.3 & 678 & 15 \\
\hline G97-18-11 & A & 4_19 & 494 & 8517 & 1.1 & 4.9 & 0.3 & 682 & 14 \\
\hline G97-18-11 & A & 4_20 & 495 & 6648 & 1.1 & 6.3 & 0.4 & 701 & 14 \\
\hline G97-18-11 & A & $5 \_11$ & 496 & 2730 & 3.8 & 15.2 & 1.4 & 779 & 22 \\
\hline G97-18-11 & A & 5_12 & 497 & 5378 & 2.4 & 7.7 & 0.6 & 719 & 17 \\
\hline G97-18-11 & A & $5 \_13$ & 498 & 5887 & 0.9 & 7.1 & 0.4 & 711 & 14 \\
\hline G97-18-11 & A & 5_14 & 499 & 6238 & 1.8 & 6.7 & 0.5 & 706 & 15 \\
\hline G97-18-11 & $\mathrm{A}$ & $5 \_15$ & 500 & 7359 & 1.7 & 5.6 & 0.4 & 693 & 15 \\
\hline G97-18-11 & A & $5 \_16$ & 501 & 8023 & 1.2 & 5.2 & 0.3 & 686 & 14 \\
\hline G97-18-11 & A & $5 \_17$ & 502 & 8773 & 2.0 & 4.7 & 0.4 & 679 & 16 \\
\hline G97-18-11 & A & 5_18 & 503 & 7681 & 1.8 & 5.4 & 0.4 & 690 & 15 \\
\hline G97-18-11 & A & 5_19 & 504 & 7389 & 1.2 & 5.6 & 0.4 & 693 & 14 \\
\hline G97-18-11 & A & 5_20 & 505 & 6136 & 1.3 & 6.8 & 0.4 & 708 & 15 \\
\hline G97-18-11 & $\mathrm{A}$ & $6 \_10$ & 506 & 3400 & 4.0 & 12.2 & 1.2 & 759 & 22 \\
\hline G97-18-11 & A & $6 \_11$ & 507 & 6206 & 1.7 & 6.7 & 0.5 & 707 & 15 \\
\hline G97-18-11 & A & $6 \_12$ & 508 & 7484 & 2.0 & 5.6 & 0.4 & 692 & 15 \\
\hline G97-18-11 & A & $6 \_13$ & 509 & 8067 & 1.0 & 5.2 & 0.3 & 686 & 14 \\
\hline G97-18-11 & $\mathrm{A}$ & $6 \_14$ & 510 & 8435 & 1.2 & 4.9 & 0.3 & 682 & 14 \\
\hline G97-18-11 & A & $6 \_15$ & 511 & 8298 & 3.7 & 5.0 & 0.5 & 684 & 19 \\
\hline G97-18-11 & A & $6 \_16$ & 512 & 8110 & 2.2 & 5.1 & 0.4 & 685 & 16 \\
\hline G97-18-11 & A & $6 \_17$ & 513 & 7500 & 1.4 & 5.5 & 0.4 & 692 & 14 \\
\hline G97-18-11 & $\mathrm{A}$ & $6 \_18$ & 514 & 6874 & 1.0 & 6.0 & 0.4 & 699 & 14 \\
\hline G97-18-11 & A & $6 \_19$ & 515 & 6696 & 0.9 & 6.2 & 0.4 & 701 & 14 \\
\hline G97-18-11 & A & $6 \_20$ & 516 & 8168 & 2.7 & 5.1 & 0.4 & 685 & 17 \\
\hline G97-18-11 & A & $7 \_9$ & 517 & 1360 & 27.0 & 30.5 & 15.6 & 850 & 127 \\
\hline G97-18-11 & A & $7 \_10$ & 518 & 5264 & 1.5 & 7.9 & 0.5 & 721 & 15 \\
\hline G97-18-11 & A & 7_11 & 519 & 7276 & 1.4 & 5.7 & 0.4 & 694 & 15 \\
\hline G97-18-11 & $\mathrm{A}$ & $7 \_12$ & 520 & 9259 & 1.1 & 4.5 & 0.3 & 675 & 14 \\
\hline G97-18-11 & A & 7_13 & 521 & 9881 & 2.4 & 4.2 & 0.3 & 670 & 16 \\
\hline G97-18-11 & A & $7 \_14$ & 522 & 8538 & 1.3 & 4.9 & 0.3 & 681 & 14 \\
\hline G97-18-11 & A & $7 \_15$ & 523 & 7945 & 0.2 & 5.2 & 0.3 & 687 & 14 \\
\hline G97-18-11 & $\mathrm{A}$ & $7 \_16$ & 524 & 7470 & 1.0 & 5.6 & 0.4 & 692 & 14 \\
\hline G97-18-11 & A & $7 \_17$ & 525 & 7641 & 0.7 & 5.4 & 0.3 & 690 & 14 \\
\hline G97-18-11 & A & $7 \_18$ & 526 & 7112 & 1.3 & 5.8 & 0.4 & 696 & 14 \\
\hline G97-18-11 & A & $7 \_19$ & 527 & 7284 & 1.0 & 5.7 & 0.4 & 694 & 14 \\
\hline G97-18-11 & A & $7 \_20$ & 528 & 8311 & 1.0 & 5.0 & 0.3 & 683 & 14 \\
\hline G97-18-11 & $\mathrm{A}$ & $8 \_8$ & 529 & 1648 & 10.8 & 25.2 & 5.4 & 829 & 52 \\
\hline G97-18-11 & A & 8_9 & 530 & 4724 & 4.1 & 8.8 & 0.9 & 730 & 21 \\
\hline G97-18-11 & A & $8 \_10$ & 531 & 6405 & 3.8 & 6.5 & 0.6 & 704 & 20 \\
\hline G97-18-11 & A & $8 \_11$ & 532 & 8561 & 1.9 & 4.9 & 0.4 & 681 & 15 \\
\hline G97-18-11 & A & $8 \_12$ & 533 & 9435 & 1.8 & 4.4 & 0.3 & 674 & 15 \\
\hline G97-18-11 & A & $8 \_13$ & 534 & 8204 & 1.1 & 5.1 & 0.3 & 684 & 14 \\
\hline G97-18-11 & A & 8_14 & 535 & 7422 & 1.1 & 5.6 & 0.4 & 692 & 14 \\
\hline G97-18-11 & A & $8 \_15$ & 536 & 6975 & 0.9 & 6.0 & 0.4 & 697 & 14 \\
\hline G97-18-11 & A & $8 \_16$ & 537 & 6471 & 2.8 & 6.4 & 0.5 & 703 & 17 \\
\hline
\end{tabular}




\begin{tabular}{|c|c|c|c|c|c|c|c|c|}
\hline G97-18-11 & A & $8 \_17$ & 538 & 6541 & 1.2 & 6.4 & 0.4 & 703 \\
\hline G97-18-11 & A & $8-18$ & 539 & 6506 & 0.8 & 6.4 & 0.4 & 703 \\
\hline G97-18-11 & A & 8_19 & 540 & 6556 & 0.7 & 6.3 & 0.4 & 702 \\
\hline G97-18-11 & A & 8_20 & 541 & 6620 & 0.7 & 6.3 & 0.4 & 702 \\
\hline G97-18-11 & A & 9_7 & 542 & 2764 & 5.7 & 15.0 & 1.9 & 778 \\
\hline G97-18-11 & A & $9 \_8$ & 543 & 5110 & 0.4 & 8.1 & 0.5 & 723 \\
\hline G97-18-11 & A & 9_9 & 544 & 7296 & 1.8 & 5.7 & 0.4 & 694 \\
\hline G97-18-11 & A & $9 \_10$ & 545 & 9965 & 1.4 & 4.2 & 0.3 & 669 \\
\hline G97-18-11 & $\mathrm{A}$ & $9-11$ & 546 & 10140 & 1.8 & 4.1 & 0.3 & 668 \\
\hline G97-18-11 & A & $9 \_12$ & 547 & 8382 & 2.2 & 5.0 & 0.4 & 683 \\
\hline G97-18-11 & A & $9-13$ & 548 & 7784 & 1.1 & 5.3 & 0.3 & 689 \\
\hline G97-18-11 & A & $9 \_14$ & 549 & 7282 & 1.3 & 5.7 & 0.4 & 694 \\
\hline G97-18-11 & A & $9 \_15$ & 550 & 7128 & 1.2 & 5.8 & 0.4 & 696 \\
\hline G97-18-11 & A & $9 \_16$ & 551 & 7027 & 1.3 & 5.9 & 0.4 & 697 \\
\hline G97-18-11 & $\mathrm{A}$ & $9 \_17$ & 552 & 7028 & 1.7 & 5.9 & 0.4 & 697 \\
\hline G97-18-11 & A & $9-18$ & 553 & 6940 & 2.4 & 6.0 & 0.5 & 698 \\
\hline G97-18-11 & A & $9-19$ & 554 & 7697 & 0.5 & 5.4 & 0.3 & 689 \\
\hline G97-18-11 & A & 9_20 & 555 & 7123 & 1.9 & 5.8 & 0.4 & 696 \\
\hline G97-18-11 & $\mathrm{A}$ & $10 \_6$ & 556 & 2856 & 6.3 & 14.5 & 2.0 & 775 \\
\hline G97-18-11 & A & $10 \_7$ & 557 & 4782 & 1.6 & 8.7 & 0.6 & 729 \\
\hline G97-18-11 & A & $10 \_8$ & 558 & 6401 & 0.5 & 6.5 & 0.4 & 704 \\
\hline G97-18-11 & A & $10 \_9$ & 559 & 8870 & 1.2 & 4.7 & 0.3 & 678 \\
\hline G97-18-11 & $\mathrm{A}$ & $10 \_10$ & 560 & 9227 & 1.3 & 4.5 & 0.3 & 675 \\
\hline G97-18-11 & A & $10 \_11$ & 561 & 9282 & 1.1 & 4.5 & 0.3 & 675 \\
\hline G97-18-11 & A & $10 \_12$ & 562 & 8746 & 1.1 & 4.8 & 0.3 & 679 \\
\hline G97-18-11 & A & $10 \_13$ & 563 & 7715 & 2.0 & 5.4 & 0.4 & 689 \\
\hline G97-18-11 & A & $10 \_14$ & 564 & 7557 & 0.4 & 5.5 & 0.3 & 691 \\
\hline G97-18-11 & A & $10 \_15$ & 565 & 7821 & 1.0 & 5.3 & 0.3 & 688 \\
\hline G97-18-11 & $\mathrm{A}$ & $10 \_16$ & 566 & 7713 & 1.3 & 5.4 & 0.4 & 689 \\
\hline G97-18-11 & A & 10_17 & 567 & 7949 & 1.5 & 5.2 & 0.4 & 687 \\
\hline G97-18-11 & A & 10_18 & 568 & 8515 & 1.3 & 4.9 & 0.3 & 682 \\
\hline G97-18-11 & A & 10_19 & 569 & 8495 & 0.8 & 4.9 & 0.3 & 682 \\
\hline G97-18-11 & $\mathrm{A}$ & $10 \_20$ & 570 & 8591 & 1.9 & 4.8 & 0.4 & 681 \\
\hline G97-18-11 & A & $11 \_6$ & 571 & 2683 & 7.9 & 15.5 & 2.5 & 781 \\
\hline G97-18-11 & A & $11] 7$ & 572 & 5148 & 2.9 & 8.1 & 0.7 & 722 \\
\hline G97-18-11 & A & $11 \_8$ & 573 & 8110 & 2.1 & 5.1 & 0.4 & 685 \\
\hline G97-18-11 & A & $11 \_9$ & 574 & 9182 & 0.9 & 4.5 & 0.3 & 676 \\
\hline G97-18-11 & $\mathrm{A}$ & $11 \_10$ & 575 & 7689 & 0.9 & 5.4 & 0.3 & 690 \\
\hline G97-18-11 & A & 11_11 & 576 & 7587 & 0.7 & 5.5 & 0.3 & 691 \\
\hline G97-18-11 & A & $11 \_12$ & 577 & 6766 & 0.4 & 6.1 & 0.4 & 700 \\
\hline G97-18-11 & A & $11 \_13$ & 578 & 6703 & 3.3 & 6.2 & 0.5 & 701 \\
\hline G97-18-11 & A & $11 \_14$ & 579 & 7824 & 1.4 & 5.3 & 0.4 & 688 \\
\hline G97-18-11 & A & $11 \_15$ & 580 & 8293 & 2.3 & 5.0 & 0.4 & 684 \\
\hline G97-18-11 & A & $11 \_16$ & 581 & 8768 & 0.7 & 4.7 & 0.3 & 679 \\
\hline G97-18-11 & A & $11 \_17$ & 582 & 8922 & 1.4 & 4.7 & 0.3 & 678 \\
\hline G97-18-11 & A & $11 \_18$ & 583 & 8699 & 0.7 & 4.8 & 0.3 & 680 \\
\hline
\end{tabular}




\begin{tabular}{|c|c|c|c|c|c|c|c|c|c|}
\hline G97-18-11 & A & $11 \_19$ & 584 & 8678 & 2.7 & 4.8 & 0.4 & 680 & 17 \\
\hline G97-18-11 & A & $11 \_20$ & 585 & 8931 & 2.1 & 4.7 & 0.4 & 678 & 16 \\
\hline G97-18-11 & A & $12 \_5$ & 586 & 533 & 8.7 & 77.9 & 13.0 & 960 & 51 \\
\hline G97-18-11 & A & $12-6$ & 587 & 2874 & 9.0 & 14.5 & 2.7 & 774 & 41 \\
\hline G97-18-11 & A & $12 \_7$ & 588 & 6602 & 1.8 & 6.3 & 0.4 & 702 & 15 \\
\hline G97-18-11 & A & $12 \_8$ & 589 & 9404 & 1.1 & 4.4 & 0.3 & 674 & 14 \\
\hline G97-18-11 & A & $12 \_9$ & 590 & 8400 & 0.4 & 4.9 & 0.3 & 683 & 14 \\
\hline G97-18-11 & A & $12 \_10$ & 591 & 7099 & 2.9 & 5.9 & 0.5 & 696 & 17 \\
\hline G97-18-11 & $\mathrm{A}$ & $12-11$ & 592 & 6543 & 1.8 & 6.4 & 0.4 & 703 & 15 \\
\hline G97-18-11 & A & $12 \_12$ & 593 & 6556 & 1.3 & 6.3 & 0.4 & 702 & 14 \\
\hline G97-18-11 & A & $12 \_13$ & 594 & 6804 & 0.5 & 6.1 & 0.4 & 699 & 14 \\
\hline G97-18-11 & A & $12 \_14$ & 595 & 7277 & 1.0 & 5.7 & 0.4 & 694 & 14 \\
\hline G97-18-11 & A & $12 \_15$ & 596 & 7999 & 2.1 & 5.2 & 0.4 & 686 & 16 \\
\hline G97-18-11 & A & $12 \_16$ & 597 & 8329 & 0.3 & 5.0 & 0.3 & 683 & 14 \\
\hline G97-18-11 & $\mathrm{A}$ & $12 \_17$ & 598 & 8339 & 1.8 & 5.0 & 0.4 & 683 & 15 \\
\hline G97-18-11 & A & $12 \_18$ & 599 & 8138 & 1.1 & 5.1 & 0.3 & 685 & 14 \\
\hline G97-18-11 & A & $12 \_19$ & 600 & 7294 & 2.0 & 5.7 & 0.4 & 694 & 15 \\
\hline G97-18-11 & A & $12 \_20$ & 601 & 6735 & 2.2 & 6.2 & 0.5 & 700 & 16 \\
\hline G97-18-11 & $\mathrm{A}$ & $13 \_5$ & 602 & 1557 & 12.0 & 26.7 & 6.4 & 835 & 59 \\
\hline G97-18-11 & A & 13 & 603 & 3087 & 8.3 & 13.5 & 2.4 & 768 & 38 \\
\hline G97-18-11 & A & $13 \_7$ & 604 & 7991 & 1.5 & 5.2 & 0.4 & 687 & 15 \\
\hline G97-18-11 & A & $13 \_8$ & 605 & 9677 & 0.9 & 4.3 & 0.3 & 672 & 14 \\
\hline G97-18-11 & $\mathrm{A}$ & 13 & 606 & 8751 & 0.7 & 4.8 & 0.3 & 679 & 14 \\
\hline G97-18-11 & A & $13 \_10$ & 607 & 7353 & 1.6 & 5.7 & 0.4 & 693 & 15 \\
\hline G97-18-11 & A & $13 \_11$ & 608 & 6837 & 1.8 & 6.1 & 0.4 & 699 & 15 \\
\hline G97-18-11 & A & $13 \_12$ & 609 & 7450 & 0.5 & 5.6 & 0.3 & 692 & 14 \\
\hline G97-18-11 & A & $13 \_13$ & 610 & 7799 & 0.8 & 5.3 & 0.3 & 688 & 14 \\
\hline G97-18-11 & A & $13 \_14$ & 611 & 8718 & 1.8 & 4.8 & 0.4 & 680 & 15 \\
\hline G97-18-11 & $\mathrm{A}$ & $13 \_15$ & 612 & 8958 & 1.6 & 4.6 & 0.3 & 678 & 15 \\
\hline G97-18-11 & A & $13 \_16$ & 613 & 8910 & 0.9 & 4.7 & 0.3 & 678 & 14 \\
\hline G97-18-11 & A & $13 \_17$ & 614 & 8561 & 2.0 & 4.9 & 0.4 & 681 & 16 \\
\hline G97-18-11 & A & $13 \_18$ & 615 & 8614 & 1.8 & 4.8 & 0.4 & 681 & 15 \\
\hline G97-18-11 & $\mathrm{A}$ & $13 \_19$ & 616 & 8346 & 2.1 & 5.0 & 0.4 & 683 & 16 \\
\hline G97-18-11 & A & $13 \_20$ & 617 & 7616 & 0.8 & 5.5 & 0.3 & 690 & 14 \\
\hline G97-18-11 & A & $14 \_5$ & 618 & 2739 & 2.1 & 15.2 & 1.1 & 779 & 18 \\
\hline G97-18-11 & A & $14 \_6$ & 619 & 5185 & 1.1 & 8.0 & 0.5 & 722 & 15 \\
\hline G97-18-11 & A & $14 \_7$ & 620 & 8501 & 2.9 & 4.9 & 0.4 & 682 & 17 \\
\hline G97-18-11 & $\mathrm{A}$ & $14 \_8$ & 621 & 8044 & 2.7 & 5.2 & 0.4 & 686 & 17 \\
\hline G97-18-11 & A & 14 -9 & 622 & 6761 & 1.2 & 6.1 & 0.4 & 700 & 14 \\
\hline G97-18-11 & A & $14 \_10$ & 623 & 5760 & 1.5 & 7.2 & 0.5 & 713 & 15 \\
\hline G97-18-11 & A & $14 \_11$ & 624 & 5953 & 1.9 & 7.0 & 0.5 & 710 & 16 \\
\hline G97-18-11 & A & $14 \_12$ & 625 & 6962 & 1.9 & 6.0 & 0.4 & 698 & 15 \\
\hline G97-18-11 & A & $14 \_13$ & 626 & 7642 & 1.4 & 5.4 & 0.4 & 690 & 15 \\
\hline G97-18-11 & A & $14 \_14$ & 627 & 7446 & 1.6 & 5.6 & 0.4 & 692 & 15 \\
\hline G97-18-11 & A & $14 \_15$ & 628 & 7954 & 2.2 & 5.2 & 0.4 & 687 & 16 \\
\hline G97-18-11 & A & $14 \_16$ & 629 & 8062 & 1.1 & 5.2 & 0.3 & 686 & 14 \\
\hline
\end{tabular}




\begin{tabular}{|c|c|c|c|c|c|c|c|c|}
\hline G97-18-11 & $\mathrm{A}$ & $14 \_17$ & 630 & 7912 & 1.5 & 5.3 & 0.4 & 687 \\
\hline G97-18-11 & A & $14 \_18$ & 631 & 7476 & 1.9 & 5.6 & 0.4 & 692 \\
\hline G97-18-11 & $\mathrm{A}$ & $14 \_19$ & 632 & 7516 & 1.6 & 5.5 & 0.4 & 691 \\
\hline G97-18-11 & $\mathrm{A}$ & $14 \_20$ & 633 & 7499 & 1.1 & 5.5 & 0.4 & 692 \\
\hline G97-18-11 & A & 15 & 634 & 336 & 8.1 & 123.5 & 19.7 & 1023 \\
\hline G97-18-11 & $\mathrm{A}$ & 15 & 635 & 2165 & 4.2 & 19.2 & 1.9 & 802 \\
\hline G97-18-11 & A & $15 \_6$ & 636 & 6671 & 0.9 & 6.2 & 0.4 & 701 \\
\hline G97-18-11 & $\mathrm{A}$ & $15 \_7$ & 637 & 9030 & 0.9 & 4.6 & 0.3 & 677 \\
\hline G97-18-11 & $\mathrm{A}$ & 15 & 638 & 7639 & 1.2 & 5.4 & 0.4 & 690 \\
\hline G97-18-11 & $\mathrm{A}$ & 15 & 639 & 6174 & 1.8 & 6.7 & 0.5 & 707 \\
\hline G97-18-11 & A & $15-10$ & 640 & 5183 & 1.7 & 8.0 & 0.5 & 722 \\
\hline G97-18-11 & $\mathrm{A}$ & $15_{-}^{-} 11$ & 641 & 5867 & 3.6 & 7.1 & 0.7 & 711 \\
\hline G97-18-11 & $\mathrm{A}$ & $15-12$ & 642 & 7710 & 2.4 & 5.4 & 0.4 & 689 \\
\hline G97-18-11 & A & $15-13$ & 643 & 8247 & 1.5 & 5.0 & 0.4 & 684 \\
\hline G97-18-11 & A & $15-14$ & 644 & 7862 & 0.7 & 5.3 & 0.3 & 688 \\
\hline G97-18-11 & A & $15 \_15$ & 645 & 7764 & 1.6 & 5.4 & 0.4 & 689 \\
\hline G97-18-11 & $\mathrm{A}$ & $15_{-}^{-} 16$ & 646 & 7937 & 2.7 & 5.2 & 0.4 & 687 \\
\hline G97-18-11 & A & $15 \_17$ & 647 & 8061 & 0.8 & 5.2 & 0.3 & 686 \\
\hline G97-18-11 & $\mathrm{A}$ & $15 \_18$ & 648 & 7584 & 2.5 & 5.5 & 0.4 & 691 \\
\hline G97-18-11 & A & $15 \_19$ & 649 & 7833 & 1.7 & 5.3 & 0.4 & 688 \\
\hline G97-18-11 & $\mathrm{A}$ & $15-20$ & 650 & 8371 & 1.2 & 5.0 & 0.3 & 683 \\
\hline G97-18-11 & $\mathrm{A}$ & $1 \overline{6} 4$ & 651 & 3632 & 5.7 & 11.4 & 1.5 & 753 \\
\hline G97-18-11 & $\mathrm{A}$ & 165 & 652 & 6869 & 2.5 & 6.1 & 0.5 & 699 \\
\hline G97-18-11 & A & 16 & 653 & 9485 & 1.1 & 4.4 & 0.3 & 673 \\
\hline G97-18-11 & A & $16 \_7$ & 654 & 9631 & 0.9 & 4.3 & 0.3 & 672 \\
\hline G97-18-11 & A & $16 \_8$ & 655 & 8412 & 0.7 & 4.9 & 0.3 & 682 \\
\hline G97-18-11 & A & 1699 & 656 & 6491 & 1.2 & 6.4 & 0.4 & 703 \\
\hline G97-18-11 & A & $16 \_10$ & 657 & 5678 & 1.2 & 7.3 & 0.5 & 714 \\
\hline G97-18-11 & A & $16 \_11$ & 658 & 6850 & 0.3 & 6.1 & 0.4 & 699 \\
\hline G97-18-11 & A & $16 \_12$ & 659 & 8814 & 1.2 & 4.7 & 0.3 & 679 \\
\hline G97-18-11 & $\mathrm{A}$ & $16 \_13$ & 660 & 9318 & 2.3 & 4.5 & 0.4 & 675 \\
\hline G97-18-11 & $\mathrm{A}$ & $16 \_14$ & 661 & 8281 & 0.6 & 5.0 & 0.3 & 684 \\
\hline G97-18-11 & $\mathrm{A}$ & $16 \_15$ & 662 & 7838 & 1.6 & 5.3 & 0.4 & 688 \\
\hline G97-18-11 & A & $16 \_16$ & 663 & 8229 & 1.6 & 5.1 & 0.4 & 684 \\
\hline G97-18-11 & $\mathrm{A}$ & $16 \_17$ & 664 & 8072 & 2.1 & 5.1 & 0.4 & 686 \\
\hline G97-18-11 & A & $16 \_18$ & 665 & 7755 & 0.9 & 5.4 & 0.3 & 689 \\
\hline G97-18-11 & A & $16 \_19$ & 666 & 8085 & 1.2 & 5.1 & 0.3 & 686 \\
\hline G97-18-11 & $\mathrm{A}$ & $16 \_20$ & 667 & 8847 & 2.6 & 4.7 & 0.4 & 679 \\
\hline G97-18-11 & $\mathrm{A}$ & $17 \_3$ & 668 & 217 & 8.8 & 191.0 & 33.6 & 1089 \\
\hline G97-18-11 & $\mathrm{A}$ & 174 & 669 & 3675 & 2.7 & 11.3 & 0.9 & 752 \\
\hline G97-18-11 & A & $17 \_5$ & 670 & 8787 & 3.1 & 4.7 & 0.4 & 679 \\
\hline G97-18-11 & $\mathrm{A}$ & $17-6$ & 671 & 10391 & 1.4 & 4.0 & 0.3 & 666 \\
\hline G97-18-11 & A & $17 \_7$ & 672 & 8975 & 0.9 & 4.6 & 0.3 & 677 \\
\hline G97-18-11 & $\mathrm{A}$ & 178 & 673 & 7510 & 0.9 & 5.5 & 0.4 & 691 \\
\hline G97-18-11 & A & 17 -9 & 674 & 5723 & 1.0 & 7.3 & 0.5 & 714 \\
\hline G97-18-11 & A & $17 \_10$ & 675 & 6030 & 1.6 & 6.9 & 0.5 & 709 \\
\hline
\end{tabular}




\begin{tabular}{|c|c|c|c|c|c|c|c|c|c|}
\hline G97-18-11 & $\mathrm{A}$ & 17_11 & 676 & 6922 & 0.7 & 6.0 & 0.4 & 698 & 14 \\
\hline G97-18-11 & A & 17_12 & 677 & 8430 & 1.8 & 4.9 & 0.4 & 682 & 15 \\
\hline G97-18-11 & $\mathrm{A}$ & $17^{-} 13$ & 678 & 6916 & 2.2 & 6.0 & 0.4 & 698 & 16 \\
\hline G97-18-11 & $\mathrm{A}$ & $17^{-} 14$ & 679 & 8898 & 1.7 & 4.7 & 0.3 & 678 & 15 \\
\hline G97-18-11 & A & $17 \_15$ & 680 & 8180 & 1.1 & 5.1 & 0.3 & 685 & 14 \\
\hline G97-18-11 & $\mathrm{A}$ & 17_16 & 681 & 8345 & 1.7 & 5.0 & 0.4 & 683 & 15 \\
\hline G97-18-11 & A & 17_17 & 682 & 8259 & 0.9 & 5.0 & 0.3 & 684 & 14 \\
\hline G97-18-11 & $\mathrm{A}$ & $17 \_18$ & 683 & 8601 & 2.0 & 4.8 & 0.4 & 681 & 16 \\
\hline G97-18-11 & $\mathrm{A}$ & 17_19 & 684 & 8996 & 0.7 & 4.6 & 0.3 & 677 & 14 \\
\hline G97-18-11 & $\mathrm{A}$ & 17_20 & 685 & 9630 & 3.4 & 4.3 & 0.4 & 672 & 18 \\
\hline G97-18-11 & A & $18 \_2$ & 686 & 92 & 39.3 & 453.2 & 337.9 & 1242 & 337 \\
\hline G97-18-11 & $\mathrm{A}$ & $18 \_3$ & 687 & 162 & 33.1 & 256.9 & 165.8 & 1138 & 253 \\
\hline G97-18-11 & $\mathrm{A}$ & $18-4$ & 688 & 2100 & 0.3 & 19.8 & 1.2 & 805 & 16 \\
\hline G97-18-11 & A & $18 \_5$ & 689 & 8511 & 2.0 & 4.9 & 0.4 & 682 & 16 \\
\hline G97-18-11 & A & $18 \_6$ & 690 & 8589 & 1.3 & 4.8 & 0.3 & 681 & 14 \\
\hline G97-18-11 & A & $18 \_7$ & 691 & 8099 & 1.4 & 5.1 & 0.4 & 685 & 15 \\
\hline G97-18-11 & $\mathrm{A}$ & $18 \_8$ & 692 & 7425 & 2.0 & 5.6 & 0.4 & 692 & 15 \\
\hline G97-18-11 & A & 18_9 & 693 & 5853 & 0.8 & 7.1 & 0.4 & 712 & 14 \\
\hline G97-18-11 & A & 18_10 & 694 & 3162 & 2.5 & 13.1 & 1.0 & 766 & 19 \\
\hline G97-18-11 & A & 18_11 & 695 & 3775 & 1.3 & 11.0 & 0.7 & 749 & 16 \\
\hline G97-18-11 & $\mathrm{A}$ & 18_12 & 696 & 6956 & 0.4 & 6.0 & 0.4 & 698 & 14 \\
\hline G97-18-11 & $\mathrm{A}$ & $18-13$ & 697 & 7497 & 0.8 & 5.5 & 0.3 & 692 & 14 \\
\hline G97-18-11 & $\mathrm{A}$ & 18_14 & 698 & 8483 & 1.5 & 4.9 & 0.3 & 682 & 15 \\
\hline G97-18-11 & A & 18_15 & 699 & 8833 & 1.2 & 4.7 & 0.3 & 679 & 14 \\
\hline G97-18-11 & A & 18_16 & 700 & 9213 & 1.1 & 4.5 & 0.3 & 675 & 14 \\
\hline G97-18-11 & A & 18_17 & 701 & 8896 & 1.9 & 4.7 & 0.4 & 678 & 15 \\
\hline G97-18-11 & A & $18 \_18$ & 702 & 9323 & 1.5 & 4.5 & 0.3 & 675 & 15 \\
\hline G97-18-11 & A & 18_19 & 703 & 10256 & 0.6 & 4.1 & 0.3 & 667 & 14 \\
\hline G97-18-11 & A & 18_20 & 704 & 8536 & 3.1 & 4.9 & 0.4 & 681 & 18 \\
\hline G97-18-11 & A & 192 & 705 & 857 & 0.2 & 48.5 & 2.8 & 902 & 19 \\
\hline G97-18-11 & $\mathrm{A}$ & $19 \_3$ & 706 & 1121 & 3.2 & 37.1 & 3.2 & 871 & 25 \\
\hline G97-18-11 & $\mathrm{A}$ & $19 \_4$ & 707 & 3514 & 4.1 & 11.8 & 1.2 & 756 & 23 \\
\hline G97-18-11 & A & $19-5$ & 708 & 9111 & 3.3 & 4.6 & 0.4 & 676 & 18 \\
\hline G97-18-11 & A & $19 \_6$ & 709 & 7753 & 0.4 & 5.4 & 0.3 & 689 & 14 \\
\hline G97-18-11 & $\mathrm{A}$ & $19-7$ & 710 & 7111 & 1.3 & 5.8 & 0.4 & 696 & 14 \\
\hline G97-18-11 & A & $19 \_8$ & 711 & 6631 & 0.9 & 6.3 & 0.4 & 701 & 14 \\
\hline G97-18-11 & A & 19_9 & 712 & 1473 & 1.0 & 28.2 & 1.7 & 841 & 18 \\
\hline G97-18-11 & $\mathrm{A}$ & 19_10 & 713 & 180 & 0.6 & 230.6 & 13.8 & 1120 & 27 \\
\hline G97-18-11 & $\mathrm{A}$ & 19_11 & 714 & 249 & 0.5 & 166.7 & 9.9 & 1068 & 25 \\
\hline G97-18-11 & $\mathrm{A}$ & 19_12 & 715 & 3711 & 0.7 & 11.2 & 0.7 & 751 & 15 \\
\hline G97-18-11 & $\mathrm{A}$ & 19_13 & 716 & 6918 & 1.2 & 6.0 & 0.4 & 698 & 14 \\
\hline G97-18-11 & $\mathrm{A}$ & 19_14 & 717 & 7770 & 1.8 & 5.3 & 0.4 & 689 & 15 \\
\hline G97-18-11 & A & $19 \_15$ & 718 & 9138 & 1.2 & 4.5 & 0.3 & 676 & 14 \\
\hline G97-18-11 & $\mathrm{A}$ & 19_16 & 719 & 9657 & 1.1 & 4.3 & 0.3 & 672 & 14 \\
\hline G97-18-11 & A & 19_17 & 720 & 9970 & 2.5 & 4.2 & 0.4 & 669 & 16 \\
\hline G97-18-11 & A & 19_18 & 721 & 10718 & 1.2 & 3.9 & 0.3 & 664 & 5 \\
\hline
\end{tabular}




\begin{tabular}{|c|c|c|c|c|c|c|c|c|c|}
\hline G97-18-11 & $\mathrm{A}$ & $19 \_19$ & 722 & 10121 & 2.4 & 4.1 & 0.3 & 668 & 16 \\
\hline G97-18-11 & $\mathrm{A}$ & 19_20 & 723 & 749 & 3.2 & 55.4 & 4.9 & 918 & 27 \\
\hline G97-18-11 & $\mathrm{A}$ & $20 \_1$ & 724 & 4151 & 3.9 & 10.0 & 1.0 & 741 & 22 \\
\hline G97-18-11 & $\mathrm{A}$ & $20 \_2$ & 725 & 6209 & 3.5 & 6.7 & 0.6 & 707 & 19 \\
\hline G97-18-11 & A & $20 \_3$ & 726 & 6526 & 1.8 & 6.4 & 0.4 & 703 & 15 \\
\hline G97-18-11 & $\mathrm{A}$ & $20 \_4$ & 727 & 9334 & 0.7 & 4.5 & 0.3 & 674 & 14 \\
\hline G97-18-11 & A & $20 \_5$ & 728 & 9769 & 2.6 & 4.3 & 0.4 & 671 & 17 \\
\hline G97-18-11 & $\mathrm{A}$ & $20 \_6$ & 729 & 8377 & 2.3 & 5.0 & 0.4 & 683 & 16 \\
\hline G97-18-11 & $\mathrm{A}$ & $20 \_7$ & 730 & 7436 & 1.6 & 5.6 & 0.4 & 692 & 15 \\
\hline G97-18-11 & $\mathrm{A}$ & $20 \_8$ & 731 & 4425 & 1.4 & 9.4 & 0.6 & 735 & 16 \\
\hline G97-18-11 & A & $20 \_9$ & 732 & 51 & 2.2 & 809.5 & 66.8 & 1365 & 47 \\
\hline G97-18-11 & $\mathrm{A}$ & $20 \_12$ & 735 & 121 & 0.8 & 343.7 & 21.1 & 1189 & 30 \\
\hline G97-18-11 & $\mathrm{A}$ & $20-13$ & 736 & 6152 & 1.5 & 6.8 & 0.4 & 708 & 15 \\
\hline G97-18-11 & A & $20 \_14$ & 737 & 8094 & 2.5 & 5.1 & 0.4 & 686 & 16 \\
\hline G97-18-11 & A & $20 \_15$ & 738 & 9350 & 1.8 & 4.4 & 0.3 & 674 & 15 \\
\hline G97-18-11 & A & $20 \_16$ & 739 & 10319 & 1.8 & 4.0 & 0.3 & 667 & 15 \\
\hline G97-18-11 & $\mathrm{A}$ & $20 \_17$ & 740 & 12525 & 1.3 & 3.3 & 0.3 & 652 & 15 \\
\hline G97-18-11 & A & $20 \_18$ & 741 & 10776 & 2.3 & 3.9 & 0.3 & 664 & 16 \\
\hline G97-18-11 & $\mathrm{A}$ & $20 \_19$ & 742 & 2414 & 4.4 & 17.2 & 1.8 & 791 & 25 \\
\hline G97-18-11 & A & $20 \_20$ & 743 & 586 & 4.5 & 70.8 & 7.8 & 948 & 34 \\
\hline G97-18-11 & A & $21 \_1$ & 744 & 5400 & 2.0 & 7.7 & 0.5 & 718 & 16 \\
\hline G97-18-11 & $\mathrm{A}$ & $21 \_2$ & 745 & 9481 & 3.3 & 4.4 & 0.4 & 673 & 18 \\
\hline G97-18-11 & $\mathrm{A}$ & $21 \_3$ & 746 & 9902 & 1.7 & 4.2 & 0.3 & 670 & 15 \\
\hline G97-18-11 & A & 214 & 747 & 11459 & 0.5 & 3.6 & 0.3 & 659 & 14 \\
\hline G97-18-11 & A & $21 \_5$ & 748 & 10757 & 1.4 & 3.9 & 0.3 & 664 & 15 \\
\hline G97-18-11 & A & $21-6$ & 749 & 9494 & 1.0 & 4.4 & 0.3 & 673 & 14 \\
\hline G97-18-11 & A & $21 \_7$ & 750 & 9170 & 1.1 & 4.5 & 0.3 & 676 & 14 \\
\hline G97-18-11 & A & $21 \_8$ & 751 & 4866 & 1.3 & 8.5 & 0.5 & 727 & 15 \\
\hline G97-18-11 & A & $21 \_9$ & 752 & 18 & 0.6 & 2350.6 & 154.1 & 1652 & 54 \\
\hline G97-18-11 & A & $21 \_12$ & 755 & 31 & 0.8 & 1333.9 & 86.9 & 1488 & 45 \\
\hline G97-18-11 & $\mathrm{A}$ & $21 \_13$ & 756 & 4404 & 1.2 & 9.4 & 0.6 & 736 & 15 \\
\hline G97-18-11 & $\mathrm{A}$ & $21 \_14$ & 757 & 8908 & 2.3 & 4.7 & 0.4 & 678 & 16 \\
\hline G97-18-11 & A & $21_{-}^{-} 15$ & 758 & 9394 & 1.2 & 4.4 & 0.3 & 674 & 14 \\
\hline G97-18-11 & A & $21 \_16$ & 759 & 5727 & 7.7 & 7.3 & 1.2 & 713 & 33 \\
\hline G97-18-11 & $\mathrm{A}$ & $21 \_17$ & 760 & 6002 & 4.2 & 6.9 & 0.7 & 710 & 21 \\
\hline G97-18-11 & A & $21 \_18$ & 761 & 536 & 3.0 & 77.5 & 6.7 & 960 & 28 \\
\hline G97-18-11 & A & $21 \_19$ & 762 & 361 & 1.2 & 114.9 & 7.3 & 1013 & 24 \\
\hline G97-18-11 & $\mathrm{A}$ & $21 \_20$ & 763 & 202 & 3.7 & 205.1 & 21.2 & 1101 & 41 \\
\hline G97-18-11 & $\mathrm{A}$ & $22 \_1$ & 764 & 9284 & 8.5 & 4.5 & 0.8 & 675 & 33 \\
\hline G97-18-11 & $\mathrm{A}$ & $22 \_2$ & 765 & 12285 & 2.6 & 3.4 & 0.3 & 654 & 17 \\
\hline G97-18-11 & $\mathrm{A}$ & $22 \_3$ & 766 & 13849 & 1.0 & 3.0 & 0.3 & 645 & 15 \\
\hline G97-18-11 & $\mathrm{A}$ & $22-4$ & 767 & 15466 & 2.0 & 2.7 & 0.3 & 637 & 17 \\
\hline G97-18-11 & A & $22 \_5$ & 768 & 12639 & 2.0 & 3.3 & 0.3 & 652 & 16 \\
\hline G97-18-11 & $\mathrm{A}$ & $22 \_6$ & 769 & 9874 & 1.2 & 4.2 & 0.3 & 670 & 15 \\
\hline G97-18-11 & A & $22 \_7$ & 770 & 9510 & 0.6 & 4.4 & 0.3 & 673 & 14 \\
\hline G97-18-11 & A & $22 \_8$ & 771 & 9079 & 1.3 & 4.6 & 0.3 & 677 & 5 \\
\hline
\end{tabular}




\begin{tabular}{|c|c|c|c|c|c|c|c|c|c|}
\hline G97-18-11 & A & 22_9 & 772 & 7551 & 1.1 & 5.5 & 0.4 & 691 & 14 \\
\hline G97-18-11 & A & $22-10$ & 773 & 683 & 0.6 & 60.8 & 3.6 & 929 & 20 \\
\hline G97-18-11 & $\mathrm{A}$ & $22 \_11$ & 774 & 953 & 0.6 & 43.6 & 2.6 & 889 & 19 \\
\hline G97-18-11 & $\mathrm{A}$ & $22-12$ & 775 & 7602 & 1.5 & 5.5 & 0.4 & 690 & 15 \\
\hline G97-18-11 & A & $22 \_13$ & 776 & 10240 & 2.3 & 4.1 & 0.3 & 667 & 16 \\
\hline G97-18-11 & A & $22-14$ & 777 & 12261 & 3.7 & 3.4 & 0.4 & 654 & 19 \\
\hline G97-18-11 & $\mathrm{A}$ & $22 \_15$ & 778 & 9660 & 2.9 & 4.3 & 0.4 & 672 & 17 \\
\hline G97-18-11 & $\mathrm{A}$ & $22-16$ & 779 & 5058 & 2.4 & 8.2 & 0.6 & 724 & 17 \\
\hline G97-18-11 & $\mathrm{A}$ & $22-17$ & 780 & 1141 & 2.1 & 36.4 & 2.6 & 869 & 21 \\
\hline G97-18-11 & A & $22-18$ & 781 & 157 & 1.7 & 265.3 & 19.0 & 1144 & 32 \\
\hline G97-18-11 & A & $22-19$ & 782 & 5 & 1.5 & 8898.2 & 2702.2 & 2192 & 365 \\
\hline G97-18-11 & A & 23 & 783 & 10571 & 6.4 & 3.9 & 0.6 & 665 & 27 \\
\hline G97-18-11 & $\mathrm{A}$ & $23 \_2$ & 784 & 17625 & 2.2 & 2.4 & 0.2 & 628 & 18 \\
\hline G97-18-11 & A & $23 \_3$ & 785 & 21075 & 1.4 & 2.0 & 0.2 & 616 & 19 \\
\hline G97-18-11 & $\mathrm{A}$ & $23-4$ & 786 & 17178 & 2.9 & 2.4 & 0.3 & 630 & 19 \\
\hline G97-18-11 & A & $23 \_5$ & 787 & 11614 & 1.6 & 3.6 & 0.3 & 658 & 15 \\
\hline G97-18-11 & $\mathrm{A}$ & $23-6$ & 788 & 8260 & 0.9 & 5.0 & 0.3 & 684 & 14 \\
\hline G97-18-11 & $\mathrm{A}$ & $23-7$ & 789 & 7469 & 1.4 & 5.6 & 0.4 & 692 & 14 \\
\hline G97-18-11 & $\mathrm{A}$ & $23 \_8$ & 790 & 8526 & 1.5 & 4.9 & 0.3 & 681 & 15 \\
\hline G97-18-11 & A & $23 \_9$ & 791 & 9303 & 0.5 & 4.5 & 0.3 & 675 & 14 \\
\hline G97-18-11 & A & $23 \_10$ & 792 & 10913 & 2.5 & 3.8 & 0.3 & 663 & 17 \\
\hline G97-18-11 & A & $23^{-} 11$ & 793 & 11124 & 1.9 & 3.7 & 0.3 & 661 & 16 \\
\hline G97-18-11 & A & $23 \_12$ & 794 & 11019 & 0.4 & 3.8 & 0.3 & 662 & 14 \\
\hline G97-18-11 & A & $23_{-}^{-} 13$ & 795 & 8992 & 1.5 & 4.6 & 0.3 & 677 & 15 \\
\hline G97-18-11 & A & $23 \_14$ & 796 & 3663 & 2.1 & 11.3 & 0.8 & 752 & 17 \\
\hline G97-18-11 & A & $23-15$ & 797 & 3410 & 1.5 & 12.2 & 0.8 & 759 & 16 \\
\hline G97-18-11 & A & $23-16$ & 798 & 3069 & 1.9 & 13.5 & 1.0 & 768 & 17 \\
\hline G97-18-11 & $\mathrm{A}$ & $23-17$ & 799 & 1383 & 2.7 & 30.0 & 2.4 & 848 & 22 \\
\hline G97-18-11 & A & $23-18$ & 800 & 336 & 1.3 & 123.7 & 8.1 & 1024 & 25 \\
\hline G97-18-11 & A & $2 \overline{4} \_1$ & 801 & 9473 & 11.0 & 4.4 & 1.0 & 673 & 42 \\
\hline G97-18-11 & A & $24 \_2$ & 802 & 13793 & 1.0 & 3.0 & 0.3 & 645 & 15 \\
\hline G97-18-11 & $\mathrm{A}$ & $24 \_3$ & 803 & 18089 & 1.4 & 2.3 & 0.2 & 626 & 17 \\
\hline G97-18-11 & $\mathrm{A}$ & $24 \_4$ & 804 & 13853 & 1.7 & 3.0 & 0.3 & 645 & 16 \\
\hline G97-18-11 & A & $24 \_5$ & 805 & 9205 & 2.6 & 4.5 & 0.4 & 676 & 17 \\
\hline G97-18-11 & A & $24 \_6$ & 806 & 7367 & 0.8 & 5.6 & 0.4 & 693 & 14 \\
\hline G97-18-11 & A & $24 \_7$ & 807 & 6891 & 1.4 & 6.0 & 0.4 & 698 & 15 \\
\hline G97-18-11 & $\mathrm{A}$ & $24 \_8$ & 808 & 8178 & 1.3 & 5.1 & 0.3 & 685 & 14 \\
\hline G97-18-11 & $\mathrm{A}$ & $24 \_9$ & 809 & 9708 & 0.9 & 4.3 & 0.3 & 671 & 14 \\
\hline G97-18-11 & $\mathrm{A}$ & $24-10$ & 810 & 9798 & 1.6 & 4.2 & 0.3 & 671 & 15 \\
\hline G97-18-11 & A & $24 \_11$ & 811 & 8510 & 0.8 & 4.9 & 0.3 & 682 & 14 \\
\hline G97-18-11 & $\mathrm{A}$ & 24_12 & 812 & 8700 & 2.2 & 4.8 & 0.4 & 680 & 16 \\
\hline G97-18-11 & A & $24-13$ & 813 & 3191 & 3.2 & 13.0 & 1.1 & 765 & 20 \\
\hline G97-18-11 & $\mathrm{A}$ & 24_14 & 814 & 2351 & 5.5 & 17.7 & 2.2 & 794 & 30 \\
\hline G97-18-11 & A & $24-15$ & 815 & 1356 & 3.1 & 30.6 & 2.6 & 850 & 24 \\
\hline G97-18-11 & A & 24_16 & 816 & 1262 & 1.9 & 32.9 & 2.3 & 858 & 20 \\
\hline G97-18-11 & A & 25 & 817 & 5903 & 8.1 & 7.0 & 1.2 & 711 & 34 \\
\hline
\end{tabular}




\begin{tabular}{|c|c|c|c|c|c|c|c|c|c|}
\hline G97-18-11 & A & 252 & 818 & 10771 & 2.2 & 3.9 & 0.3 & 664 & 16 \\
\hline G97-18-11 & A & $25 \_3$ & 819 & 14231 & 2.2 & 2.9 & 0.3 & 643 & 17 \\
\hline G97-18-11 & A & 254 & 820 & 10436 & 1.7 & 4.0 & 0.3 & 666 & 15 \\
\hline G97-18-11 & $\mathrm{A}$ & $25-5$ & 821 & 7156 & 3.2 & 5.8 & 0.5 & 695 & 18 \\
\hline G97-18-11 & A & $25-6$ & 822 & 8772 & 2.0 & 4.7 & 0.4 & 679 & 16 \\
\hline G97-18-11 & A & $25^{-} 7$ & 823 & 9148 & 2.0 & 4.5 & 0.4 & 676 & 16 \\
\hline G97-18-11 & A & 258 & 824 & 8935 & 1.9 & 4.7 & 0.3 & 678 & 15 \\
\hline G97-18-11 & A & 25 & 825 & 5245 & 1.6 & 7.9 & 0.5 & 721 & 15 \\
\hline G97-18-11 & $\mathrm{A}$ & $25 \_10$ & 826 & 6362 & 1.7 & 6.5 & 0.4 & 705 & 15 \\
\hline G97-18-11 & A & $25-11$ & 827 & 10074 & 1.9 & 4.1 & 0.3 & 669 & 16 \\
\hline G97-18-11 & A & $25-12$ & 828 & 7074 & 2.6 & 5.9 & 0.5 & 696 & 17 \\
\hline G97-18-11 & A & $25-13$ & 829 & 4118 & 5.5 & 10.1 & 1.3 & 742 & 27 \\
\hline G97-18-11 & $\mathrm{A}$ & $25-14$ & 830 & 1395 & 3.3 & 29.8 & 2.7 & 847 & 25 \\
\hline G97-18-11 & A & 26 & 831 & 5135 & 16.3 & 8.1 & 2.7 & 723 & 66 \\
\hline G97-18-11 & $\mathrm{A}$ & $26 \_3$ & 832 & 763 & 11.4 & 54.4 & 13.9 & 915 & 72 \\
\hline G97-18-11 & A & 264 & 833 & 1480 & 17.3 & 28.1 & 10.3 & 841 & 90 \\
\hline G97-18-11 & $\mathrm{A}$ & 265 & 834 & 5141 & 2.0 & 8.1 & 0.6 & 723 & 16 \\
\hline G97-18-11 & A & 26 & 835 & 1383 & 31.7 & 30.0 & 20.0 & 848 & 165 \\
\hline G97-18-11 & $\mathrm{A}$ & 26 & 836 & 2932 & 0.9 & 14.2 & 0.9 & 773 & 16 \\
\hline G97-18-11 & A & 268 & 837 & 770 & 2.9 & 53.9 & 4.6 & 914 & 26 \\
\hline G97-18-11 & A & 269 & 838 & 1393 & 5.0 & 29.8 & 3.6 & 847 & 31 \\
\hline G97-18-11 & A & $26 \_10$ & 839 & 1898 & 2.9 & 21.9 & 1.8 & 815 & 22 \\
\hline G97-18-11 & A & $26 \_11$ & 840 & 3710 & 4.5 & 11.2 & 1.2 & 751 & 24 \\
\hline G97-18-11 & A & $26-12$ & 841 & 2286 & 6.3 & 18.2 & 2.6 & 796 & 33 \\
\hline G97-18-11 & $\mathrm{B}$ & $1 \_1$ & 842 & 1837 & 3.4 & 22.6 & 2.1 & 818 & 24 \\
\hline G97-18-11 & $\mathrm{B}$ & $1 \_2$ & 843 & 1899 & 1.1 & 21.9 & 1.4 & 815 & 17 \\
\hline G97-18-11 & B & $1 \_3$ & 844 & 29 & 9.0 & 1430.9 & 890.9 & 1507 & 389 \\
\hline G97-18-11 & $\mathrm{B}$ & $1 \_4$ & 845 & 495 & 11.4 & 83.9 & 22.5 & 970 & 82 \\
\hline G97-18-11 & $\mathrm{B}$ & $1 \_5$ & 846 & 768 & 1.7 & 54.1 & 3.8 & 915 & 22 \\
\hline G97-18-11 & $\mathrm{B}$ & $1 \_6$ & 847 & 2652 & 1.9 & 15.7 & 1.1 & 782 & 18 \\
\hline G97-18-11 & $\mathrm{B}$ & $1] 7$ & 848 & 1839 & 1.3 & 22.6 & 1.5 & 818 & 18 \\
\hline G97-18-11 & $\mathrm{B}$ & $1 \_8$ & 849 & 2076 & 3.8 & 20.0 & 2.0 & 806 & 24 \\
\hline G97-18-11 & $\mathrm{B}$ & $1-9$ & 850 & 2495 & 0.5 & 16.6 & 1.0 & 788 & 16 \\
\hline G97-18-11 & $\mathrm{B}$ & $1 \_10$ & 851 & 4900 & 1.7 & 8.5 & 0.6 & 727 & 16 \\
\hline G97-18-11 & $\mathrm{B}$ & $1 \_11$ & 852 & 5479 & 3.5 & 7.6 & 0.7 & 717 & 20 \\
\hline G97-18-11 & B & $1 \_12$ & 853 & 4447 & 5.5 & 9.3 & 1.2 & 735 & 27 \\
\hline G97-18-11 & $\mathrm{B}$ & $1 \_13$ & 854 & 5950 & 4.2 & 7.0 & 0.7 & 710 & 21 \\
\hline G97-18-11 & $\mathrm{B}$ & $1 \_14$ & 855 & 6614 & 3.6 & 6.3 & 0.6 & 702 & 19 \\
\hline G97-18-11 & B & $1 \_15$ & 856 & 2353 & 4.6 & 17.7 & 2.0 & 793 & 27 \\
\hline G97-18-11 & $\mathrm{B}$ & $2-1$ & 857 & 4335 & 2.5 & 9.6 & 0.7 & 737 & 18 \\
\hline G97-18-11 & $\mathrm{B}$ & $2 \_2$ & 858 & 4008 & 1.0 & 10.4 & 0.6 & 744 & 15 \\
\hline G97-18-11 & $\mathrm{B}$ & $2 \_3$ & 859 & 2903 & 1.2 & 14.3 & 0.9 & 773 & 16 \\
\hline G97-18-11 & $\mathrm{B}$ & $2 \_4$ & 860 & 4928 & 1.0 & 8.4 & 0.5 & 726 & 15 \\
\hline G97-18-11 & $\mathrm{B}$ & $2 \_5$ & 861 & 9618 & 1.1 & 4.3 & 0.3 & 672 & 14 \\
\hline G97-18-11 & B & $2 \_6$ & 862 & 8608 & 1.6 & 4.8 & 0.3 & 681 & 15 \\
\hline G97-18-11 & B & $2 \_7$ & 863 & 7993 & 0.8 & 5.2 & 0.3 & 687 & 14 \\
\hline
\end{tabular}




\begin{tabular}{|c|c|c|c|c|c|c|c|c|c|}
\hline G97-18-11 & B & $2 \_8$ & 864 & 9099 & 2.0 & 4.6 & 0.4 & 676 & 16 \\
\hline G97-18-11 & B & 2_9 & 865 & 8910 & 1.3 & 4.7 & 0.3 & 678 & 15 \\
\hline G97-18-11 & B & $2 \_10$ & 866 & 11745 & 1.2 & 3.5 & 0.3 & 657 & 15 \\
\hline G97-18-11 & B & $2-11$ & 867 & 13311 & 2.4 & 3.1 & 0.3 & 648 & 17 \\
\hline G97-18-11 & $\mathrm{B}$ & $2 \_12$ & 868 & 14397 & 2.2 & 2.9 & 0.3 & 642 & 17 \\
\hline G97-18-11 & B & $2 \_13$ & 869 & 15935 & 2.5 & 2.6 & 0.3 & 635 & 18 \\
\hline G97-18-11 & B & $2-14$ & 870 & 15672 & 3.7 & 2.7 & 0.3 & 636 & 20 \\
\hline G97-18-11 & B & $2 \_15$ & 871 & 7062 & 3.5 & 5.9 & 0.5 & 696 & 19 \\
\hline G97-18-11 & B & 3 & 872 & 7758 & 2.7 & 5.4 & 0.4 & 689 & 17 \\
\hline G97-18-11 & B & 3_2 & 873 & 6559 & 1.6 & 6.3 & 0.4 & 702 & 15 \\
\hline G97-18-11 & B & 3_3 & 874 & 5978 & 0.5 & 7.0 & 0.4 & 710 & 14 \\
\hline G97-18-11 & B & 3_4 & 875 & 7350 & 2.0 & 5.7 & 0.4 & 693 & 15 \\
\hline G97-18-11 & B & $3 \_5$ & 876 & 7889 & 1.1 & 5.3 & 0.3 & 688 & 14 \\
\hline G97-18-11 & $\mathrm{B}$ & $3 \_6$ & 877 & 6878 & 0.8 & 6.0 & 0.4 & 698 & 14 \\
\hline G97-18-11 & B & $3-7$ & 878 & 6581 & 0.7 & 6.3 & 0.4 & 702 & 14 \\
\hline G97-18-11 & B & $3 \_8$ & 879 & 6792 & 2.9 & 6.1 & 0.5 & 699 & 17 \\
\hline G97-18-11 & B & 3_9 & 880 & 7377 & 1.3 & 5.6 & 0.4 & 693 & 14 \\
\hline G97-18-11 & B & 3_10 & 881 & 11338 & 0.6 & 3.7 & 0.3 & 660 & 14 \\
\hline G97-18-11 & $\mathrm{B}$ & 3_11 & 882 & 13984 & 1.6 & 3.0 & 0.3 & 644 & 16 \\
\hline G97-18-11 & B & $3 \_12$ & 883 & 14065 & 1.3 & 3.0 & 0.3 & 644 & 16 \\
\hline G97-18-11 & B & $3 \_13$ & 884 & 14058 & 3.3 & 3.0 & 0.3 & 644 & 19 \\
\hline G97-18-11 & B & $3 \_14$ & 885 & 16369 & 1.5 & 2.5 & 0.2 & 633 & 17 \\
\hline G97-18-11 & B & $3 \_15$ & 886 & 8960 & 4.2 & 4.6 & 0.5 & 678 & 20 \\
\hline G97-18-11 & B & $4 \_1$ & 887 & 7479 & 2.2 & 5.6 & 0.4 & 692 & 16 \\
\hline G97-18-11 & B & $4 \_2$ & 888 & 6551 & 0.2 & 6.3 & 0.4 & 702 & 14 \\
\hline G97-18-11 & B & $4 \_3$ & 889 & 6615 & 1.0 & 6.3 & 0.4 & 702 & 14 \\
\hline G97-18-11 & B & $4+4$ & 890 & 6899 & 1.3 & 6.0 & 0.4 & 698 & 14 \\
\hline G97-18-11 & B & $4 \_5$ & 891 & 7308 & 0.9 & 5.7 & 0.4 & 694 & 14 \\
\hline G97-18-11 & B & 4_6 & 892 & 7807 & 1.0 & 5.3 & 0.3 & 688 & 14 \\
\hline G97-18-11 & B & 4_7 & 893 & 7941 & 2.2 & 5.2 & 0.4 & 687 & 16 \\
\hline G97-18-11 & B & 4_8 & 894 & 6651 & 1.9 & 6.2 & 0.4 & 701 & 15 \\
\hline G97-18-11 & B & $4 \_9$ & 895 & 6100 & 2.2 & 6.8 & 0.5 & 708 & 16 \\
\hline G97-18-11 & $\mathrm{B}$ & $4 \_10$ & 896 & 7633 & 2.8 & 5.4 & 0.5 & 690 & 17 \\
\hline G97-18-11 & B & 4_11 & 897 & 10095 & 1.9 & 4.1 & 0.3 & 668 & 16 \\
\hline G97-18-11 & B & $4 \_12$ & 898 & 12110 & 2.2 & 3.4 & 0.3 & 655 & 16 \\
\hline G97-18-11 & B & $4 \_13$ & 899 & 13446 & 3.0 & 3.1 & 0.3 & 647 & 18 \\
\hline G97-18-11 & B & $4 \_14$ & 900 & 15365 & 3.2 & 2.7 & 0.3 & 638 & 19 \\
\hline G97-18-11 & $\mathrm{B}$ & $4 \_15$ & 901 & 9655 & 2.0 & 4.3 & 0.3 & 672 & 16 \\
\hline G97-18-11 & B & 5_1 & 902 & 6719 & 0.9 & 6.2 & 0.4 & 700 & 14 \\
\hline G97-18-11 & B & $5 \_2$ & 903 & 5649 & 1.3 & 7.4 & 0.5 & 715 & 15 \\
\hline G97-18-11 & B & $5 \_3$ & 904 & 5975 & 0.4 & 7.0 & 0.4 & 710 & 14 \\
\hline G97-18-11 & B & 5_4 & 905 & 6366 & 1.4 & 6.5 & 0.4 & 705 & 15 \\
\hline G97-18-11 & B & 5_5 & 906 & 6428 & 1.2 & 6.5 & 0.4 & 704 & 14 \\
\hline G97-18-11 & B & $5 \_6$ & 907 & 6829 & 1.2 & 6.1 & 0.4 & 699 & 14 \\
\hline G97-18-11 & B & $5-7$ & 908 & 7369 & 1.7 & 5.6 & 0.4 & 693 & 15 \\
\hline G97-18-11 & B & 5_8 & 909 & 8249 & 2.3 & 5.0 & 0.4 & 684 & 16 \\
\hline
\end{tabular}




\begin{tabular}{|c|c|c|c|c|c|c|c|c|}
\hline G97-18-11 & B & 5_9 & 910 & 8494 & 1.0 & 4.9 & 0.3 & 682 \\
\hline G97-18-11 & B & $5 \_10$ & 911 & 6370 & 2.1 & 6.5 & 0.5 & 705 \\
\hline G97-18-11 & B & 5_11 & 912 & 5981 & 1.5 & 6.9 & 0.5 & 710 \\
\hline G97-18-11 & $\mathrm{B}$ & $5 \_12$ & 913 & 8421 & 1.5 & 4.9 & 0.3 & 682 \\
\hline G97-18-11 & $\mathrm{B}$ & $5 \_13$ & 914 & 11722 & 1.2 & 3.5 & 0.3 & 657 \\
\hline G97-18-11 & $\mathrm{B}$ & $5 \_14$ & 915 & 15291 & 1.0 & 2.7 & 0.2 & 638 \\
\hline G97-18-11 & $\mathrm{B}$ & $5 \_15$ & 916 & 10535 & 2.5 & 3.9 & 0.3 & 665 \\
\hline G97-18-11 & $\mathrm{B}$ & $6 \_1$ & 917 & 7158 & 0.8 & 5.8 & 0.4 & 695 \\
\hline G97-18-11 & $\mathrm{B}$ & $6 \_2$ & 918 & 6853 & 1.8 & 6.1 & 0.4 & 699 \\
\hline G97-18-11 & B & $6 \_3$ & 919 & 7235 & 1.1 & 5.7 & 0.4 & 694 \\
\hline G97-18-11 & $\mathrm{B}$ & $6+4$ & 920 & 7420 & 0.9 & 5.6 & 0.4 & 692 \\
\hline G97-18-11 & B & $6 \_5$ & 921 & 7378 & 2.3 & 5.6 & 0.4 & 693 \\
\hline G97-18-11 & B & $6 \_6$ & 922 & 7641 & 1.3 & 5.4 & 0.4 & 690 \\
\hline G97-18-11 & $\mathrm{B}$ & $6 \_7$ & 923 & 7908 & 2.1 & 5.3 & 0.4 & 687 \\
\hline G97-18-11 & $\mathrm{B}$ & $6 \_8$ & 924 & 7006 & 1.3 & 5.9 & 0.4 & 697 \\
\hline G97-18-11 & $\mathrm{B}$ & 6_9 & 925 & 8386 & 0.4 & 5.0 & 0.3 & 683 \\
\hline G97-18-11 & $\mathrm{B}$ & $6 \_10$ & 926 & 6940 & 1.3 & 6.0 & 0.4 & 698 \\
\hline G97-18-11 & $\mathrm{B}$ & $6 \_11$ & 927 & 5233 & 1.6 & 7.9 & 0.5 & 721 \\
\hline G97-18-11 & $\mathrm{B}$ & $6 \_12$ & 928 & 7500 & 0.7 & 5.5 & 0.3 & 692 \\
\hline G97-18-11 & $\mathrm{B}$ & $6 \_13$ & 929 & 10942 & 1.7 & 3.8 & 0.3 & 662 \\
\hline G97-18-11 & B & $6 \_14$ & 930 & 13026 & 2.1 & 3.2 & 0.3 & 650 \\
\hline G97-18-11 & B & $6 \_15$ & 931 & 3391 & 3.6 & 12.2 & 1.2 & 759 \\
\hline G97-18-11 & $\mathrm{B}$ & $7 \_1$ & 932 & 7414 & 1.6 & 5.6 & 0.4 & 692 \\
\hline G97-18-11 & B & 72 & 933 & 8305 & 1.5 & 5.0 & 0.4 & 684 \\
\hline G97-18-11 & $\mathrm{B}$ & $7 \_3$ & 934 & 8397 & 1.0 & 4.9 & 0.3 & 683 \\
\hline G97-18-11 & $\mathrm{B}$ & 74 & 935 & 8453 & 2.5 & 4.9 & 0.4 & 682 \\
\hline G97-18-11 & $\mathrm{B}$ & $7-5$ & 936 & 8987 & 1.7 & 4.6 & 0.3 & 677 \\
\hline G97-18-11 & B & $7 \_6$ & 937 & 9214 & 1.9 & 4.5 & 0.3 & 675 \\
\hline G97-18-11 & $\mathrm{B}$ & $7 \_7$ & 938 & 9600 & 1.5 & 4.3 & 0.3 & 672 \\
\hline G97-18-11 & B & 7_8 & 939 & 9415 & 0.9 & 4.4 & 0.3 & 674 \\
\hline G97-18-11 & $\mathrm{B}$ & 7_9 & 940 & 5918 & 0.9 & 7.0 & 0.4 & 711 \\
\hline G97-18-11 & B & $7 \_10$ & 941 & 887 & 10.4 & 46.8 & 11.4 & 898 \\
\hline G97-18-11 & $\mathrm{B}$ & 7_11 & 942 & 4443 & 4.3 & 9.4 & 1.0 & 735 \\
\hline G97-18-11 & $\mathrm{B}$ & $7 \_12$ & 943 & 8673 & 2.1 & 4.8 & 0.4 & 680 \\
\hline G97-18-11 & B & $7 \_13$ & 944 & 11592 & 1.6 & 3.6 & 0.3 & 658 \\
\hline G97-18-11 & $\mathrm{B}$ & $7 \_14$ & 945 & 10971 & 2.3 & 3.8 & 0.3 & 662 \\
\hline G97-18-11 & B & $7 \_15$ & 946 & 4526 & 0.8 & 9.2 & 0.6 & 733 \\
\hline G97-18-11 & $\mathrm{B}$ & $8 \_1$ & 947 & 7079 & 1.4 & 5.9 & 0.4 & 696 \\
\hline G97-18-11 & B & 8_2 & 948 & 6172 & 2.0 & 6.7 & 0.5 & 707 \\
\hline G97-18-11 & $\mathrm{B}$ & $8 \_3$ & 949 & 7326 & 0.6 & 5.7 & 0.4 & 693 \\
\hline G97-18-11 & B & $8 \_4$ & 950 & 8234 & 1.0 & 5.0 & 0.3 & 684 \\
\hline G97-18-11 & B & $8 \_5$ & 951 & 8696 & 1.9 & 4.8 & 0.4 & 680 \\
\hline G97-18-11 & B & $8 \_6$ & 952 & 8936 & 2.7 & 4.7 & 0.4 & 678 \\
\hline G97-18-11 & $\mathrm{B}$ & $8 \_7$ & 953 & 9675 & 0.8 & 4.3 & 0.3 & 672 \\
\hline G97-18-11 & $\mathrm{B}$ & $8 \_8$ & 954 & 10252 & 2.1 & 4.1 & 0.3 & 667 \\
\hline G97-18-11 & $\mathrm{B}$ & 8_9 & 955 & 6905 & 0.8 & 6.0 & 0.4 & 698 \\
\hline
\end{tabular}




\begin{tabular}{|c|c|c|c|c|c|c|c|c|c|}
\hline G97-18-11 & B & $8 \_10$ & 956 & 2038 & 1.2 & 20.4 & 1.3 & 808 & 17 \\
\hline G97-18-11 & B & 8_11 & 957 & 2247 & 0.4 & 18.5 & 1.1 & 798 & 16 \\
\hline G97-18-11 & B & 8_12 & 958 & 8097 & 1.6 & 5.1 & 0.4 & 685 & 15 \\
\hline G97-18-11 & B & $8 \_13$ & 959 & 11315 & 2.5 & 3.7 & 0.3 & 660 & 17 \\
\hline G97-18-11 & B & 8_14 & 960 & 8274 & 2.7 & 5.0 & 0.4 & 684 & 17 \\
\hline G97-18-11 & B & $8 \_15$ & 961 & 1555 & 18.7 & 26.7 & 10.9 & 835 & 99 \\
\hline G97-18-11 & B & 9_1 & 962 & 7655 & 2.7 & 5.4 & 0.4 & 690 & 17 \\
\hline G97-18-11 & B & 9_2 & 963 & 7637 & 2.4 & 5.4 & 0.4 & 690 & 16 \\
\hline G97-18-11 & B & 9_3 & 964 & 7610 & 2.5 & 5.5 & 0.4 & 690 & 17 \\
\hline G97-18-11 & B & $9 \_4$ & 965 & 7874 & 0.6 & 5.3 & 0.3 & 688 & 14 \\
\hline G97-18-11 & B & $9 \_5$ & 966 & 7996 & 2.1 & 5.2 & 0.4 & 686 & 16 \\
\hline G97-18-11 & B & 9_6 & 967 & 9103 & 1.7 & 4.6 & 0.3 & 676 & 15 \\
\hline G97-18-11 & B & $9 \_7$ & 968 & 10839 & 1.3 & 3.8 & 0.3 & 663 & 15 \\
\hline G97-18-11 & B & $9 \_8$ & 969 & 10963 & 2.5 & 3.8 & 0.3 & 662 & 17 \\
\hline G97-18-11 & B & $9 \_9$ & 970 & 6869 & 2.3 & 6.1 & 0.5 & 699 & 16 \\
\hline G97-18-11 & B & $9 \_10$ & 971 & 1248 & 0.7 & 33.3 & 2.0 & 859 & 18 \\
\hline G97-18-11 & B & $9 \_11$ & 972 & 1213 & 0.7 & 34.2 & 2.1 & 862 & 18 \\
\hline G97-18-11 & B & $9 \_12$ & 973 & 4692 & 0.9 & 8.9 & 0.5 & 730 & 15 \\
\hline G97-18-11 & B & $9 \_13$ & 974 & 6158 & 3.2 & 6.7 & 0.6 & 707 & 18 \\
\hline G97-18-11 & B & $9 \_14$ & 975 & 3200 & 20.9 & 13.0 & 5.7 & 764 & 94 \\
\hline G97-18-11 & B & $10 \_1$ & 977 & 8779 & 1.7 & 4.7 & 0.3 & 679 & 15 \\
\hline G97-18-11 & B & $10 \_2$ & 978 & 9342 & 2.4 & 4.4 & 0.4 & 674 & 16 \\
\hline G97-18-11 & B & $10 \_3$ & 979 & 8958 & 1.8 & 4.6 & 0.3 & 678 & 15 \\
\hline G97-18-11 & B & $10 \_4$ & 980 & 7738 & 1.5 & 5.4 & 0.4 & 689 & 15 \\
\hline G97-18-11 & B & $10 \_5$ & 981 & 8072 & 1.4 & 5.1 & 0.4 & 686 & 15 \\
\hline G97-18-11 & B & $10 \_6$ & 982 & 9178 & 1.4 & 4.5 & 0.3 & 676 & 15 \\
\hline G97-18-11 & B & $10 \_7$ & 983 & 10391 & 1.6 & 4.0 & 0.3 & 666 & 15 \\
\hline G97-18-11 & B & $10 \_8$ & 984 & 9868 & 3.0 & 4.2 & 0.4 & 670 & 18 \\
\hline G97-18-11 & B & $10 \_9$ & 985 & 7150 & 1.0 & 5.8 & 0.4 & 695 & 14 \\
\hline G97-18-11 & B & 10_10 & 986 & 1556 & 1.0 & 26.7 & 1.7 & 835 & 18 \\
\hline G97-18-11 & B & $10 \_11$ & 987 & 1143 & 0.9 & 36.3 & 2.2 & 869 & 19 \\
\hline G97-18-11 & B & 10_12 & 988 & 2291 & 0.7 & 18.1 & 1.1 & 796 & 16 \\
\hline G97-18-11 & B & 10_13 & 989 & 1434 & 2.2 & 29.0 & 2.2 & 844 & 21 \\
\hline G97-18-11 & B & $10 \_14$ & 990 & 393 & 1.8 & 105.8 & 8.0 & 1002 & 27 \\
\hline G97-18-11 & B & $11 \_1$ & 991 & 7702 & 2.2 & 5.4 & 0.4 & 689 & 16 \\
\hline G97-18-11 & B & $11 \_2$ & 992 & 8843 & 2.4 & 4.7 & 0.4 & 679 & 16 \\
\hline G97-18-11 & B & $11 \_3$ & 993 & 9447 & 1.3 & 4.4 & 0.3 & 674 & 15 \\
\hline G97-18-11 & B & $11 \_4$ & 994 & 8772 & 2.1 & 4.7 & 0.4 & 679 & 16 \\
\hline G97-18-11 & B & $11 \_5$ & 995 & 8113 & 2.7 & 5.1 & 0.4 & 685 & 17 \\
\hline G97-18-11 & B & $11 \_6$ & 996 & 8372 & 0.4 & 5.0 & 0.3 & 683 & 14 \\
\hline G97-18-11 & B & $11 \_7$ & 997 & 9813 & 1.0 & 4.2 & 0.3 & 671 & 14 \\
\hline G97-18-11 & B & $11 \_8$ & 998 & 10278 & 1.2 & 4.0 & 0.3 & 667 & 15 \\
\hline G97-18-11 & B & $11 \_9$ & 999 & 8942 & 1.5 & 4.6 & 0.3 & 678 & 15 \\
\hline G97-18-11 & B & $11 \_10$ & 1000 & 3039 & 1.0 & 13.7 & 0.9 & 769 & 16 \\
\hline G97-18-11 & B & $11 \_11$ & 1001 & 1781 & 0.8 & 23.3 & 1.4 & 821 & 17 \\
\hline G97-18-11 & B & $11 \_12$ & 1002 & 1316 & 0.9 & 31.6 & 2.0 & 853 & 18 \\
\hline
\end{tabular}




\begin{tabular}{|c|c|c|c|c|c|c|c|c|c|}
\hline G97-18-11 & B & $11 \_13$ & 1003 & 659 & 6.1 & 63.1 & 10.1 & 934 & 47 \\
\hline G97-18-11 & $\mathrm{B}$ & 11_14 & 1004 & 141 & 2.6 & 295.4 & 36.4 & 1162 & 52 \\
\hline G97-18-11 & B & $12 \_1$ & 1005 & 7005 & 1.1 & 5.9 & 0.4 & 697 & 14 \\
\hline G97-18-11 & $\mathrm{B}$ & $12 \_2$ & 1006 & 8325 & 1.1 & 5.0 & 0.3 & 683 & 14 \\
\hline G97-18-11 & $\mathrm{B}$ & $12 \_3$ & 1007 & 8610 & 1.4 & 4.8 & 0.3 & 681 & 15 \\
\hline G97-18-11 & $\mathrm{B}$ & $12-4$ & 1008 & 9018 & 0.4 & 4.6 & 0.3 & 677 & 14 \\
\hline G97-18-11 & $\mathrm{B}$ & $12 \_5$ & 1009 & 8419 & 0.4 & 4.9 & 0.3 & 682 & 14 \\
\hline G97-18-11 & $\mathrm{B}$ & $12-6$ & 1010 & 9202 & 1.5 & 4.5 & 0.3 & 676 & 15 \\
\hline G97-18-11 & $\mathrm{B}$ & $12^{-} 7$ & 1011 & 10259 & 1.2 & 4.1 & 0.3 & 667 & 15 \\
\hline G97-18-11 & B & $12 \_8$ & 1012 & 9587 & 0.5 & 4.3 & 0.3 & 672 & 14 \\
\hline G97-18-11 & $\mathrm{B}$ & $12 \_9$ & 1013 & 9900 & 1.7 & 4.2 & 0.3 & 670 & 15 \\
\hline G97-18-11 & $\mathrm{B}$ & $12 \_10$ & 1014 & 8334 & 0.8 & 5.0 & 0.3 & 683 & 14 \\
\hline G97-18-11 & B & $12 \_11$ & 1015 & 6141 & 1.7 & 6.8 & 0.5 & 708 & 15 \\
\hline G97-18-11 & $\mathrm{B}$ & $12 \_12$ & 1016 & 1253 & 14.5 & 33.2 & 10.9 & 859 & 84 \\
\hline G97-18-11 & $\mathrm{B}$ & 13 & 1018 & 7065 & 1.2 & 5.9 & 0.4 & 696 & 14 \\
\hline G97-18-11 & $\mathrm{B}$ & 132 & 1019 & 8735 & 1.3 & 4.8 & 0.3 & 680 & 15 \\
\hline G97-18-11 & $\mathrm{B}$ & 13 & 1020 & 9220 & 2.4 & 4.5 & 0.4 & 675 & 16 \\
\hline G97-18-11 & $\mathrm{B}$ & 13 & 1021 & 8469 & 1.8 & 4.9 & 0.4 & 682 & 15 \\
\hline G97-18-11 & $\mathrm{B}$ & $13 \_5$ & 1022 & 601 & 1.6 & 69.0 & 4.9 & 945 & 24 \\
\hline G97-18-11 & $\mathrm{B}$ & 13 & 1023 & 682 & 0.8 & 60.9 & 3.7 & 929 & 21 \\
\hline G97-18-11 & B & $13 \_7$ & 1024 & 4622 & 1.4 & 9.0 & 0.6 & 732 & 15 \\
\hline G97-18-11 & B & $13 \_8$ & 1025 & 8177 & 4.2 & 5.1 & 0.5 & 685 & 21 \\
\hline G97-18-11 & $\mathrm{B}$ & $13 \_9$ & 1026 & 4186 & 12.9 & 9.9 & 2.7 & 740 & 56 \\
\hline G97-18-11 & $\mathrm{B}$ & 13_10 & 1027 & 99 & 10.7 & 419.3 & 234.2 & 1227 & 248 \\
\hline G97-18-11 & $\mathrm{B}$ & $14 \_1$ & 1030 & 7318 & 2.4 & 5.7 & 0.4 & 694 & 16 \\
\hline G97-18-11 & $\mathrm{B}$ & 142 & 1031 & 8631 & 0.4 & 4.8 & 0.3 & 680 & 14 \\
\hline G97-18-11 & $\mathrm{B}$ & $14 \_3$ & 1032 & 6738 & 1.7 & 6.2 & 0.4 & 700 & 15 \\
\hline G97-18-11 & $\mathrm{B}$ & $14 \_4$ & 1033 & 77 & 0.4 & 542.1 & 34.2 & 1278 & 34 \\
\hline G97-18-11 & $\mathrm{B}$ & $14 \_7$ & 1036 & 642 & 0.8 & 64.7 & 4.0 & 937 & 21 \\
\hline G97-18-11 & B & $14 \_8$ & 1037 & 7204 & 1.1 & 5.8 & 0.4 & 695 & 14 \\
\hline G97-18-11 & $\mathrm{B}$ & $14 \_9$ & 1038 & 3640 & 3.3 & 11.4 & 1.0 & 753 & 21 \\
\hline G97-18-11 & B & $15 \_1$ & 1041 & 8276 & 1.3 & 5.0 & 0.3 & 684 & 15 \\
\hline G97-18-11 & $\mathrm{B}$ & $15 \_2$ & 1042 & 9077 & 1.1 & 4.6 & 0.3 & 677 & 14 \\
\hline G97-18-11 & $\mathrm{B}$ & $15 \_3$ & 1043 & 5754 & 1.6 & 7.2 & 0.5 & 713 & 15 \\
\hline G97-18-11 & B & $15 \_4$ & 1044 & 157 & 0.3 & 263.7 & 15.8 & 1142 & 28 \\
\hline G97-18-11 & $\mathrm{B}$ & 15 & 1047 & 267 & 0.4 & 155.5 & 9.3 & 1057 & 25 \\
\hline G97-18-11 & B & $15 \_8$ & 1048 & 1355 & 3.9 & 30.7 & 3.3 & 850 & 28 \\
\hline G97-18-11 & $\mathrm{B}$ & $16 \_1$ & 1050 & 9032 & 0.5 & 4.6 & 0.3 & 677 & 14 \\
\hline G97-18-11 & B & $16 \_2$ & 1051 & 10092 & 1.9 & 4.1 & 0.3 & 668 & 16 \\
\hline G97-18-11 & B & $16 \_3$ & 1052 & 11938 & 4.6 & 3.5 & 0.4 & 656 & 22 \\
\hline G97-18-11 & B & $16 \_4$ & 1053 & 9370 & 1.7 & 4.4 & 0.3 & 674 & 15 \\
\hline G97-18-11 & $\mathrm{B}$ & $16 \_5$ & 1054 & 3328 & 1.0 & 12.5 & 0.8 & 761 & 16 \\
\hline G97-18-11 & B & $16 \_6$ & 1055 & 702 & 9.4 & 59.2 & 14.3 & 926 & 69 \\
\hline G97-18-11 & B & $17 \_1$ & 1058 & 9582 & 0.6 & 4.3 & 0.3 & 672 & 14 \\
\hline G97-18-11 & $\mathrm{B}$ & $17 \_$ & 1059 & 8918 & 2.8 & 4.7 & 0.4 & 678 & 17 \\
\hline G97-18-11 & B & $17 \_3$ & 1060 & 9852 & 1.8 & 4.2 & 0.3 & 670 & 15 \\
\hline
\end{tabular}




\begin{tabular}{|c|c|c|c|c|c|c|c|c|c|}
\hline G97-18-11 & B & 17_4 & 1061 & 1921 & 0.6 & 21.6 & 1.3 & 814 & 17 \\
\hline G97-18-11 & B & $17 \_5$ & 1062 & 407 & 27.6 & 102.1 & 80.8 & 997 & 251 \\
\hline G97-18-11 & B & $17^{-} 6$ & 1063 & 599 & 15.3 & 69.4 & 27.8 & 946 & 118 \\
\hline G97-18-11 & B & $18-1$ & 1065 & 1085 & 0.5 & 38.3 & 2.3 & 875 & 19 \\
\hline G97-18-11 & B & $18 \_2$ & 1066 & 927 & 0.4 & 44.8 & 2.6 & 892 & 19 \\
\hline G97-18-11 & B & $18 \_3$ & 1067 & 582 & 4.3 & 71.3 & 9.1 & 949 & 39 \\
\hline G97-18-11 & B & 18_4 & 1068 & 525 & 2.7 & 79.1 & 7.3 & 962 & 30 \\
\hline G97-18-11 & B & $19 \_1$ & 1070 & 6 & 1.4 & 6893.4 & 5954.2 & 2066 & 931 \\
\hline G97-18-11 & B & $19 \_3$ & 1072 & 109 & 1.1 & 381.6 & 31.9 & 1209 & 39 \\
\hline FC1-7 & A & $1 \_2$ & 281 & 2971 & 1.2 & 14.0 & 0.9 & 771 & 16 \\
\hline FC1-7 & A & $1 \_3$ & 282 & 1924 & 2.0 & 21.6 & 1.5 & 813 & 19 \\
\hline FC1-7 & A & $1 \_4$ & 283 & 381 & 3.2 & 108.9 & 7.2 & 1006 & 25 \\
\hline $\mathrm{FC} 1-7$ & A & $1 \_2$ & 284 & 3044 & 0.8 & 13.6 & 0.8 & 769 & 16 \\
\hline $\mathrm{FC} 1-7$ & A & $1 \_3$ & 285 & 2014 & 1.6 & 20.6 & 1.4 & 809 & 18 \\
\hline $\mathrm{FC} 1-7$ & A & $1 \_4$ & 286 & 479 & 0.3 & 86.7 & 5.1 & 975 & 21 \\
\hline $\mathrm{FC} 1-7$ & A & $2-1$ & 287 & 1069 & 14.2 & 38.9 & 9.3 & 876 & 63 \\
\hline $\mathrm{FC} 1-7$ & A & $2 \_2$ & 288 & 2587 & 0.7 & 16.1 & 1.0 & 784 & 16 \\
\hline $\mathrm{FC} 1-7$ & A & $2 \_3$ & 289 & 1893 & 0.8 & 21.9 & 1.3 & 815 & 17 \\
\hline $\mathrm{FC} 1-7$ & A & 24 & 290 & 597 & 1.1 & 69.6 & 4.2 & 946 & 21 \\
\hline $\mathrm{FC} 1-7$ & A & 3_1 & 291 & 3922 & 2.1 & 10.6 & 0.7 & 746 & 17 \\
\hline $\mathrm{FC} 1-7$ & A & $3 \_2$ & 292 & 2977 & 0.7 & 14.0 & 0.8 & 771 & 16 \\
\hline $\mathrm{FC} 1-7$ & A & $3 \_3$ & 293 & 1916 & 0.5 & 21.7 & 1.3 & 814 & 17 \\
\hline $\mathrm{FC} 1-7$ & A & $3 \_4$ & 294 & 1865 & 0.9 & 22.3 & 1.4 & 817 & 17 \\
\hline $\mathrm{FC} 1-7$ & A & $3 \_5$ & 295 & 1272 & 4.4 & 32.6 & 3.1 & 857 & 26 \\
\hline $\mathrm{FC} 1-7$ & A & $4 \_1$ & 296 & 4076 & 3.1 & 10.2 & 0.9 & 743 & 19 \\
\hline $\mathrm{FC} 1-7$ & A & $4 \_2$ & 297 & 3216 & 0.6 & 12.9 & 0.8 & 764 & 15 \\
\hline $\mathrm{FC} 1-7$ & A & $4 \_3$ & 298 & 1965 & 0.5 & 21.1 & 1.3 & 811 & 17 \\
\hline $\mathrm{FC} 1-7$ & A & $4 \_4$ & 299 & 1942 & 0.6 & 21.4 & 1.3 & 812 & 17 \\
\hline $\mathrm{FC} 1-7$ & A & $4 \_5$ & 300 & 1840 & 0.2 & 22.6 & 1.3 & 818 & 17 \\
\hline $\mathrm{FC} 1-7$ & A & $4 \_6$ & 301 & 985 & 3.4 & 42.2 & 3.4 & 885 & 24 \\
\hline $\mathrm{FC} 1-7$ & A & $5 \_2$ & 302 & 3165 & 0.3 & 13.1 & 0.8 & 765 & 15 \\
\hline $\mathrm{FC} 1-7$ & A & $5 \_3$ & 303 & 2038 & 0.7 & 20.4 & 1.2 & 808 & 17 \\
\hline $\mathrm{FC} 1-7$ & A & $5 \_4$ & 304 & 1941 & 0.4 & 21.4 & 1.3 & 813 & 17 \\
\hline $\mathrm{FC} 1-7$ & A & $5 \_5$ & 305 & 1951 & 0.5 & 21.3 & 1.3 & 812 & 17 \\
\hline $\mathrm{FC} 1-7$ & A & $5 \_6$ & 306 & 1699 & 2.0 & 24.4 & 1.7 & 826 & 19 \\
\hline $\mathrm{FC} 1-7$ & A & $6 \_2$ & 307 & 3474 & 1.2 & 12.0 & 0.8 & 757 & 16 \\
\hline $\mathrm{FC} 1-7$ & A & $6 \_3$ & 308 & 2155 & 0.4 & 19.3 & 1.1 & 802 & 16 \\
\hline $\mathrm{FC} 1-7$ & A & $6 \_4$ & 309 & 1922 & 0.3 & 21.6 & 1.3 & 814 & 17 \\
\hline $\mathrm{FC} 1-7$ & A & $6 \_5$ & 310 & 2032 & 0.7 & 20.4 & 1.2 & 808 & 17 \\
\hline $\mathrm{FC} 1-7$ & A & $6 \_6$ & 311 & 570 & 8.1 & 72.8 & 9.0 & 952 & 38 \\
\hline $\mathrm{FC} 1-7$ & A & $6 \_7$ & 312 & 221 & 1.2 & 187.9 & 11.0 & 1087 & 25 \\
\hline $\mathrm{FC} 1-7$ & A & 7_1 & 313 & 2537 & 17.8 & 16.4 & 5.5 & 786 & 75 \\
\hline $\mathrm{FC} 1-7$ & A & $7 \_2$ & 314 & 3546 & 2.3 & 11.7 & 0.9 & 755 & 17 \\
\hline $\mathrm{FC} 1-7$ & A & $7 \_3$ & 315 & 2238 & 0.5 & 18.6 & 1.1 & 798 & 16 \\
\hline FC1-7 & A & $7 \_4$ & 316 & 1961 & 0.4 & 21.2 & 1.3 & 812 & 17 \\
\hline
\end{tabular}




\begin{tabular}{|c|c|c|c|c|c|c|c|c|c|}
\hline $\mathrm{FC} 1-7$ & A & $7 \_5$ & 317 & 2086 & 0.4 & 19.9 & 1.2 & 805 & 16 \\
\hline $\mathrm{FC} 1-7$ & A & $7 \_6$ & 318 & 2003 & 0.8 & 20.7 & 1.3 & 809 & 17 \\
\hline $\mathrm{FC} 1-7$ & A & 7_7 & 319 & 1371 & 12.5 & 30.3 & 6.8 & 849 & 57 \\
\hline $\mathrm{FC} 1-7$ & A & $8 \_2$ & 320 & 4288 & 0.5 & 9.7 & 0.6 & 738 & 15 \\
\hline $\mathrm{FC} 1-7$ & A & $8 \_3$ & 321 & 2360 & 0.7 & 17.6 & 1.1 & 793 & 16 \\
\hline $\mathrm{FC} 1-7$ & A & $8 \_4$ & 322 & 2005 & 0.7 & 20.7 & 1.2 & 809 & 17 \\
\hline $\mathrm{FC} 1-7$ & A & $8 \_5$ & 323 & 1935 & 0.3 & 21.5 & 1.3 & 813 & 17 \\
\hline $\mathrm{FC} 1-7$ & A & $8 \_6$ & 324 & 2154 & 0.4 & 19.3 & 1.1 & 802 & 16 \\
\hline FC1-7 & A & $8 \_7$ & 325 & 1807 & 0.3 & 23.0 & 1.4 & 820 & 17 \\
\hline $\mathrm{FC} 1-7$ & A & $8 \_8$ & 326 & 965 & 1.1 & 43.0 & 2.6 & 888 & 19 \\
\hline $\mathrm{FC} 1-7$ & A & $9 \_2$ & 327 & 5223 & 2.5 & 8.0 & 0.6 & 721 & 17 \\
\hline $\mathrm{FC} 1-7$ & A & $9 \_3$ & 328 & 2613 & 0.4 & 15.9 & 0.9 & 783 & 16 \\
\hline $\mathrm{FC} 1-7$ & A & $9 \_4$ & 329 & 2013 & 0.5 & 20.6 & 1.2 & 809 & 17 \\
\hline $\mathrm{FC} 1-7$ & A & $9 \_5$ & 330 & 1879 & 0.2 & 22.1 & 1.3 & 816 & 17 \\
\hline FC1-7 & A & 9 & 331 & 2124 & 0.9 & 19.6 & 1.2 & 804 & 17 \\
\hline $\mathrm{FC} 1-7$ & A & $9+7$ & 332 & 2001 & 0.5 & 20.8 & 1.2 & 809 & 17 \\
\hline $\mathrm{FC} 1-7$ & A & $9 \_8$ & 333 & 1696 & 0.7 & 24.5 & 1.5 & 826 & 17 \\
\hline $\mathrm{FC} 1-7$ & A & 9_9 & 334 & 441 & 3.9 & 94.1 & 7.1 & 986 & 26 \\
\hline $\mathrm{FC} 1-7$ & A & $10 \_2$ & 335 & 5132 & 5.3 & 8.1 & 1.0 & 723 & 25 \\
\hline $\mathrm{FC} 1-7$ & A & $10 \_3$ & 336 & 2984 & 1.8 & 13.9 & 0.9 & 771 & 17 \\
\hline $\mathrm{FC} 1-7$ & A & $10 \_4$ & 337 & 2208 & 0.8 & 18.8 & 1.1 & 800 & 17 \\
\hline $\mathrm{FC} 1-7$ & A & $10 \_5$ & 338 & 1899 & 0.5 & 21.9 & 1.3 & 815 & 17 \\
\hline $\mathrm{FC} 1-7$ & $\mathrm{~A}$ & $10 \_6$ & 339 & 1963 & 0.2 & 21.2 & 1.2 & 811 & 17 \\
\hline $\mathrm{FC} 1-7$ & A & $10 \_7$ & 340 & 2065 & 0.5 & 20.1 & 1.2 & 806 & 17 \\
\hline $\mathrm{FC} 1-7$ & A & $10 \_8$ & 341 & 1833 & 1.0 & 22.7 & 1.4 & 818 & 17 \\
\hline $\mathrm{FC} 1-7$ & A & $10 \_9$ & 342 & 1614 & 1.0 & 25.7 & 1.6 & 831 & 18 \\
\hline $\mathrm{FC} 1-7$ & A & $11 \_3$ & 343 & 3750 & 1.9 & 11.1 & 0.8 & 750 & 17 \\
\hline $\mathrm{FC} 1-7$ & A & $11 \_4$ & 344 & 2328 & 0.6 & 17.8 & 1.1 & 795 & 16 \\
\hline FC1-7 & A & $11 \_5$ & 345 & 1979 & 0.6 & 21.0 & 1.3 & 811 & 17 \\
\hline FC1-7 & A & $11 \_6$ & 346 & 1805 & 0.7 & 23.0 & 1.4 & 820 & 17 \\
\hline $\mathrm{FC} 1-7$ & A & $11 \_7$ & 347 & 1930 & 0.7 & 21.5 & 1.3 & 813 & 17 \\
\hline $\mathrm{FC} 1-7$ & A & $11 \_8$ & 348 & 2003 & 0.7 & 20.7 & 1.2 & 809 & 17 \\
\hline FC1-7 & A & $11 \_9$ & 349 & 1756 & 0.9 & 23.6 & 1.4 & 823 & 17 \\
\hline FC1-7 & A & $11 \_10$ & 350 & 342 & 9.9 & 121.5 & 14.2 & 1021 & 41 \\
\hline $\mathrm{FC} 1-7$ & A & $12 \_3$ & 351 & 2809 & 4.6 & 14.8 & 1.5 & 777 & 24 \\
\hline $\mathrm{FC} 1-7$ & A & $12 \_4$ & 352 & 2315 & 1.0 & 17.9 & 1.1 & 795 & 17 \\
\hline $\mathrm{FC} 1-7$ & A & $12 \_5$ & 353 & 2090 & 1.0 & 19.9 & 1.2 & 805 & 17 \\
\hline $\mathrm{FC} 1-7$ & A & $12 \_6$ & 354 & 1859 & 0.3 & 22.3 & 1.3 & 817 & 17 \\
\hline FC1-7 & A & $12 \_7$ & 355 & 1820 & 0.3 & 22.8 & 1.3 & 819 & 17 \\
\hline $\mathrm{FC} 1-7$ & A & $12 \_8$ & 356 & 1862 & 0.6 & 22.3 & 1.3 & 817 & 17 \\
\hline $\mathrm{FC} 1-7$ & A & $12 \_9$ & 357 & 1864 & 0.8 & 22.3 & 1.3 & 817 & 17 \\
\hline $\mathrm{FC} 1-7$ & A & $12 \_10$ & 358 & 1098 & 4.0 & 37.8 & 3.4 & 873 & 25 \\
\hline $\mathrm{FC} 1-7$ & A & $12 \_11$ & 359 & 198 & 16.8 & 209.3 & 17.7 & 1104 & 35 \\
\hline $\mathrm{FC} 1-7$ & A & $13 \_4$ & 360 & 2678 & 1.0 & 15.5 & 1.0 & 781 & 16 \\
\hline $\mathrm{FC} 1-7$ & A & $13 \_5$ & 361 & 2175 & 0.6 & 19.1 & 1.1 & 801 & 16 \\
\hline $\mathrm{FC} 1-7$ & A & $13 \_6$ & 362 & 2062 & 0.7 & 20.1 & 1.2 & 806 & 17 \\
\hline
\end{tabular}




\begin{tabular}{|c|c|c|c|c|c|c|c|c|c|}
\hline $\mathrm{FC} 1-7$ & A & $13 \_7$ & 363 & 1840 & 0.3 & 22.6 & 1.3 & 818 & 17 \\
\hline $\mathrm{FC} 1-7$ & A & $13 \_8$ & 364 & 1736 & 0.5 & 23.9 & 1.4 & 824 & 17 \\
\hline $\mathrm{FC} 1-7$ & A & $13 \_9$ & 365 & 1676 & 0.7 & 24.8 & 1.5 & 827 & 17 \\
\hline $\mathrm{FC} 1-7$ & A & 13_10 & 366 & 1694 & 0.5 & 24.5 & 1.5 & 826 & 17 \\
\hline $\mathrm{FC} 1-7$ & A & 13_11 & 367 & 796 & 27.9 & 52.2 & 23.5 & 910 & 125 \\
\hline $\mathrm{FC} 1-7$ & B & $1 \_3$ & 368 & 4008 & 6.0 & 10.4 & 1.3 & 744 & 28 \\
\hline $\mathrm{FC} 1-7$ & B & $1 \_4$ & 369 & 2043 & 1.6 & 20.3 & 1.3 & 807 & 18 \\
\hline $\mathrm{FC} 1-7$ & B & $1 \_5$ & 370 & 2262 & 0.5 & 18.4 & 1.1 & 797 & 16 \\
\hline FC1-7 & B & $1 \_6$ & 371 & 2105 & 0.8 & 19.7 & 1.2 & 804 & 17 \\
\hline $\mathrm{FC} 1-7$ & B & 17 & 372 & 1635 & 0.6 & 25.4 & 1.5 & 830 & 17 \\
\hline $\mathrm{FC} 1-7$ & B & $1 \_8$ & 373 & 1511 & 0.2 & 27.5 & 1.6 & 838 & 17 \\
\hline $\mathrm{FC} 1-7$ & B & $1 \_9$ & 374 & 1479 & 0.6 & 28.1 & 1.7 & 841 & 18 \\
\hline $\mathrm{FC} 1-7$ & B & $1 \_10$ & 375 & 343 & 1.6 & 121.1 & 7.4 & 1021 & 24 \\
\hline $\mathrm{FC} 1-7$ & B & $2 \_4$ & 376 & 3512 & 3.1 & 11.8 & 1.0 & 756 & 20 \\
\hline FC1-7 & B & $2 \_5$ & 377 & 2202 & 0.9 & 18.9 & 1.2 & 800 & 17 \\
\hline $\mathrm{FC} 1-7$ & B & $2 \_6$ & 378 & 2393 & 0.5 & 17.4 & 1.0 & 792 & 16 \\
\hline $\mathrm{FC} 1-7$ & B & $2 \_7$ & 379 & 2078 & 1.3 & 20.0 & 1.3 & 806 & 17 \\
\hline $\mathrm{FC} 1-7$ & B & $2 \_8$ & 380 & 1544 & 0.4 & 26.9 & 1.6 & 836 & 17 \\
\hline $\mathrm{FC} 1-7$ & B & 29 & 381 & 1438 & 0.7 & 28.9 & 1.7 & 844 & 18 \\
\hline $\mathrm{FC} 1-7$ & B & $2 \_10$ & 382 & 1417 & 0.7 & 29.3 & 1.8 & 845 & 18 \\
\hline $\mathrm{FC} 1-7$ & B & $2 \_11$ & 383 & 992 & 5.0 & 41.8 & 4.3 & 885 & 29 \\
\hline $\mathrm{FC} 1-7$ & B & $3 \_5$ & 384 & 2193 & 3.0 & 18.9 & 1.5 & 800 & 21 \\
\hline $\mathrm{FC} 1-7$ & B & $3 \_6$ & 385 & 2449 & 0.6 & 17.0 & 1.0 & 790 & 16 \\
\hline $\mathrm{FC} 1-7$ & B & $3 \_7$ & 386 & 2759 & 0.7 & 15.1 & 0.9 & 778 & 16 \\
\hline $\mathrm{FC} 1-7$ & B & $3 \_8$ & 387 & 2046 & 0.5 & 20.3 & 1.2 & 807 & 17 \\
\hline $\mathrm{FC} 1-7$ & B & $3 \_9$ & 388 & 1514 & 1.1 & 27.4 & 1.7 & 838 & 18 \\
\hline $\mathrm{FC} 1-7$ & B & $3 \_10$ & 389 & 1370 & 0.6 & 30.3 & 1.8 & 849 & 18 \\
\hline $\mathrm{FC} 1-7$ & B & $3 \_11$ & 390 & 819 & 4.1 & 50.7 & 4.5 & 907 & 27 \\
\hline FC1-7 & B & $3 \_12$ & 391 & 173 & 5.3 & 240.7 & 14.6 & 1127 & 27 \\
\hline FC1-7 & B & $4 \_6$ & 392 & 2341 & 1.0 & 17.7 & 1.1 & 794 & 17 \\
\hline $\mathrm{FC} 1-7$ & B & $4 \_7$ & 393 & 2382 & 1.2 & 17.4 & 1.1 & 792 & 17 \\
\hline $\mathrm{FC} 1-7$ & B & $4 \_8$ & 394 & 2431 & 0.7 & 17.1 & 1.0 & 790 & 16 \\
\hline FC1-7 & B & $4 \_9$ & 395 & 1896 & 0.3 & 21.9 & 1.3 & 815 & 17 \\
\hline FC1-7 & B & 4_10 & 396 & 1489 & 0.8 & 27.9 & 1.7 & 840 & 18 \\
\hline $\mathrm{FC} 1-7$ & B & 4_11 & 397 & 1432 & 0.5 & 29.0 & 1.7 & 844 & 18 \\
\hline $\mathrm{FC} 1-7$ & B & 4_12 & 398 & 786 & 34.3 & 52.8 & 29.8 & 912 & 156 \\
\hline $\mathrm{FC} 1-7$ & B & $5 \_7$ & 399 & 1628 & 8.5 & 25.5 & 4.3 & 831 & 41 \\
\hline $\mathrm{FC} 1-7$ & B & $5 \_8$ & 400 & 2342 & 0.3 & 17.7 & 1.0 & 794 & 16 \\
\hline FC1-7 & B & $5 \_9$ & 401 & 2391 & 0.9 & 17.4 & 1.1 & 792 & 16 \\
\hline $\mathrm{FC} 1-7$ & B & $5 \_10$ & 402 & 1824 & 0.2 & 22.8 & 1.3 & 819 & 17 \\
\hline $\mathrm{FC} 1-7$ & B & $5 \_11$ & 403 & 1316 & 0.4 & 31.5 & 1.9 & 853 & 18 \\
\hline $\mathrm{FC} 1-7$ & B & 5_12 & 404 & 1286 & 0.3 & 32.3 & 1.9 & 856 & 18 \\
\hline $\mathrm{FC} 1-7$ & B & $5 \_13$ & 405 & 360 & 0.9 & 115.5 & 6.9 & 1014 & 23 \\
\hline FC1-7 & B & $6 \_8$ & 406 & 2432 & 1.8 & 17.1 & 1.2 & 790 & 18 \\
\hline $\mathrm{FC} 1-7$ & B & 6_9 & 407 & 2272 & 0.6 & 18.3 & 1.1 & 797 & 16 \\
\hline $\mathrm{FC} 1-7$ & B & $6 \_10$ & 408 & 2211 & 0.6 & 18.8 & 1.1 & 800 & 16 \\
\hline
\end{tabular}




\begin{tabular}{|c|c|c|c|c|c|c|c|c|}
\hline FC1-7 & B & $6 \_11$ & 409 & 1668 & 1.0 & 24.9 & 1.5 & 828 \\
\hline $\mathrm{FC} 1-7$ & B & $6 \_12$ & 410 & 1342 & 1.0 & 30.9 & 1.9 & 851 \\
\hline $\mathrm{FC} 1-7$ & B & $6 \_13$ & 411 & 372 & 1.9 & 111.5 & 7.0 & 1009 \\
\hline FC1-7 & B & 7_8 & 412 & 1867 & 1.9 & 22.2 & 1.5 & 816 \\
\hline FC1-7 & B & 7_9 & 413 & 2148 & 0.8 & 19.3 & 1.2 & 802 \\
\hline FC1-7 & B & 710 & 414 & 2048 & 1.0 & 20.3 & 1.2 & 807 \\
\hline FC1-7 & B & $7 \_11$ & 415 & 1992 & 0.3 & 20.9 & 1.2 & 810 \\
\hline FC1-7 & B & $7 \_12$ & 416 & 1152 & 1.2 & 36.0 & 2.2 & 868 \\
\hline FC1-7 & B & $7-13$ & 417 & 237 & 1.6 & 175.0 & 10.5 & 1076 \\
\hline FC1-7 & B & $8-9$ & 418 & 2347 & 1.6 & 17.7 & 1.2 & 794 \\
\hline FC1-7 & B & $8 \_10$ & 419 & 1967 & 0.7 & 21.1 & 1.3 & 811 \\
\hline $\mathrm{FC} 1-7$ & B & 8_11 & 420 & 1886 & 0.7 & 22.0 & 1.3 & 815 \\
\hline FC1-7 & B & $8 \_12$ & 421 & 1659 & 0.4 & 25.0 & 1.5 & 829 \\
\hline FC1-7 & B & 8_13 & 422 & 301 & 2.1 & 138.1 & 8.7 & 1040 \\
\hline FC1-7 & B & $9 \_10$ & 423 & 2267 & 1.2 & 18.3 & 1.2 & 797 \\
\hline FC1-7 & B & 9_11 & 424 & 1848 & 1.4 & 22.5 & 1.4 & 817 \\
\hline FC1-7 & B & $9 \_12$ & 425 & 1600 & 1.7 & 26.0 & 1.7 & 832 \\
\hline FC1-7 & B & 9_13 & 426 & 1076 & 3.1 & 38.6 & 3.1 & 875 \\
\hline FC1-7 & B & $10-11$ & 427 & 1724 & 4.7 & 24.1 & 2.5 & 825 \\
\hline FC1-7 & B & $10 \_12$ & 428 & 601 & 1.3 & 69.1 & 4.3 & 945 \\
\hline FC1-7 & B & $1 \_3$ & 429 & 3080 & 0.8 & 13.5 & 0.8 & 768 \\
\hline FC1-7 & B & 144 & 430 & 2070 & 0.2 & 20.1 & 1.2 & 806 \\
\hline FC1-7 & B & $1 \_5$ & 431 & 2095 & 0.9 & 19.8 & 1.2 & 805 \\
\hline FC1-7 & B & 16 & 432 & 1820 & 0.7 & 22.8 & 1.4 & 819 \\
\hline FC1-7 & B & $1 \_7$ & 433 & 1493 & 0.3 & 27.8 & 1.6 & 840 \\
\hline FC1-7 & B & $1 \_8$ & 434 & 1415 & 0.6 & 29.3 & 1.7 & 845 \\
\hline FC1-7 & B & $1 \_9$ & 435 & 1427 & 0.5 & 29.1 & 1.7 & 844 \\
\hline FC1-7 & B & $1 \_10$ & 436 & 196 & 19.3 & 211.6 & 32.1 & 1106 \\
\hline
\end{tabular}

